\title{
ARTICLES
}

\section{THE BURDENS OF QUALIFIED IMMUNITY: SUMMARY JUDGMENT AND THE ROLE OF FACTS IN CONSTITUTIONAL TORT LAW}

\author{
ALAN K. CHEN*
}

\section{TABLE OF CONTENTS}

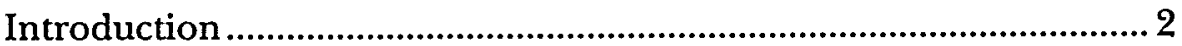

I. Qualified Immunity as Gatekeeper............................................ 10

A. The Court's Early Emphasis on Fairness and Overde-

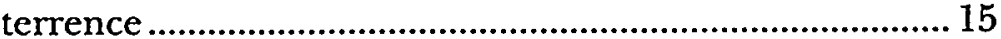

B. The Transformation of Qualified Immunity..................... 17

II. The Role of Facts in Qualified Immunity Analysis ................... 28

A. The Basic Factual Dispute ................................................. 28

B. The Inherently Fact-Based Nature of the Qualified Immunity "Reasonableness" Standard ................................ 33

C. The Confluence of the Qualified Immunity Standard with Substantive Constitutional Law.................................. 43

1. Qualified immunity and constitutional standards....... 44

2. Qualified immunity and constitutional rules ................50

III. Summary Judgment as Gatekeeper ...........................................55

* Assistant Professor, Universily of Denver College of Law. B.A., 1982, Case Western Reserve University; J.D., 1985, Stanford Law School I acknowledge with gratitude the insights of David Barnes, Arthur Best, Karen Blum, Nancy Ehrenreich, Martha Ertman, Steve Greenberger, Sheila Hyatt, Julie Nice, Steve Pepper, and Bob Weisberg, who read and commented on earlier drafts of this Article. I also thank Dean Dennis Lynch and the University of Denver College of Law for summer research support, and Faculty Services Librarian, Diane Burkhardt, and my assistant, Leslie Pagett, for their great research and technical support. Finally, I thank my able research assistants, Tracy Craige, Troy Valdez, Michael Zieg, and especially, Wendy Hess, Paul Karlsgodt, and Michael Power. All errors remain my sole responsibility. The author discloses that he was counsel for the plaintiff/appellant in one case cited in this Article, Nelson v. Streeter, 16 F.3d 145 (7th Cir. 1994). 
A. The Allocation of Burdens When the Nonmoving Party Bears the Burden of Persuasion ................................. 58

1. The moving party's initial burdens ..............................58

2. The nonmoving party's burden of production and the quantum of evidence necessary to meet the burden

B. The Allocation of Burdens When the Moving Party

Bears the Burden of Persuasion.......................................... 66

IV. Understanding the Doctrinal Consequences of Qualified Immunity's Factual Nature.

A. Ascertaining the Elusive Summary Judgment Standard for "Qualified" Immunity .................................................... 70

B. Lower Courts' Responses to the Hybrid Nature of Qualified Immunity-Contextual Alteration of Summary Judgment Doctrine.................................................. 79

C. Understanding Burdens of Persuasion on a LegallyBased Affirmative Defense 90

V. Understanding the Practical Consequences of Qualified Immunity's Factual Nature-The Creation of Secondary Burdens

\section{INTRODUCTION}

In recent years, federal courts have devoted increasing resources to adjudicating government officials' claims of immunity from constitutional tort actions. 'This litigation has focused primarily on the qualified immunity doctrine, which protects public officials from damages liability and, theoretically, from the burdens of pretrial litigation and trial, as long as their alleged unconstitutional conduct "does not violate clearly established ... constitutional rights of which a reasonable person would have known." This Article examines and criticizes the

1. By "constitutional torts," this Article refers to damages actions brought against public officials in their individual capacities for the deprivation of federal constitutional rights. Such actions against state or local officials are authorized by federal statute, 42 U.S.C. $\$ 1983$ (1994), as amended by Federal Courts Improvement Act of 1996, Pub. L. No. 104-317, 1996 U.S.C.C.A.N. (110 Stat.) 3847, while federal officials may be sued directly under the Constitution. See Bivens v. Six Unknown Named Agents of Fed. Bureau of Narcotics, 403 U.S. 388, 399 (1971) (implying Fourth Amendment cause of action for damages against federal officers). The Supreme Court has held that the immunity doctrines should be applied identically in both $\S 1983$ actions and Bivens actions. See, e.g., Butz v. Economou, 438 U.S. 478, 500 (1978). But cf. Gary S. Gildin, Immunizing Intentional Violations of Constilutiomal Rights Through Judicial Legislation: The Extension of Harlow v. Fitzgerald to Section 1983 Actions, 38 EMORY L.J. 369, 369-71 (1989) (arguing that the Court inappropriately extended qualified immunity in Bivens actions to $\S 1983$ actions, for which examination of congressional intent is relevant).

2. Harlow v. Fitzgerald, 457 U.S. 800, 818 (1982). The Supreme Court has addressed 
Supreme Court's paradoxical approach to crafting qualified immunity law, which simultaneously encourages resolution of the defense on summary judgment and shapes the doctrine to ensure an almost inevitable factual inquiry that precludes pretrial termination of civil rights claims.

Both Congress ${ }^{3}$ and the Supreme Court ${ }^{4}$ have recognized that the enforcement of constitutional norms through damages actions is an important component of our legal system. Nonetheless, the Court established the qualified immunity doctrine to limit officials' exposure to such litigation in order to advance three policy considerations. First, the Court fears that it would be unfair to require public officials to compensate plaintiffs for all constitutional violations, given the sometimes unclear nature of constitutional law. ${ }^{5}$ Second, the Court speculates that public officials will be overdeterred in the performance of their duties if they anticipate that every official action

qualified immunity issues in each of its past four terms. See Richardson v. McKnight, $117 \mathrm{~S}$. Ct. 2100,2108 (1997) (holding that prison guards employed by private company that operates prisons pursuant to contract with a state are not entitled to assert qualified immunity defense to $\$ 1983$ claims); Johnson v. Fankell, 117 S. Ct. 1800, 1802 (1997) (holding that federal law does not require state courts to permit officials whose qualified immunity claims are denied at the trial court level to pursue an interlocutory appeal); Behrens v. Pelletier, 516 U.S. 299, 311-12 (1996) (holding that Court of Appeals was not deprived of jurisdiction over defendant's second interlocutory appeal on qualified immunity issue); Johnson v. Jones, 515 U.S. 304, 304 (1995) (holding that defendant may not appeal denial of summary judgment motion based on qualified immunity when order is based on existence of "genuine" issue of material fact); Elder v. Holloway, 510 U.S. 510, 516 (1994) (finding appellate courts reviewing qualified immunity cases must consider all relevant precedents and not merely those presented to or found by the trial court). In 1995, the Court granted certiorari to hear another qualified immunity case, Kimberlin v. Quinlan, 513 U.S. 1123 (1995), granting cert. to 17 F.3d 1525 (D.C. Cir. 1994), but ultimately vacated the case and remanded it for reconsideration in light of its holding in Johnson v. Jones. See Kimberlin v. Quinlan, 515 U.S. 321 (1995). The Court has again granted certiorari to review an important qualified immunity issue during its present Term. See CrawfordEl v. Britton, 93 F.3d 813 (D.C. Cir. 1996) (en banc), cert. granted, 117 S. Ct. 2451 (1997). As this Article goes to print, the Crawford-El case, which is discussed extensively herein, see infra Part IV.B, is scheduled for oral argument before the Supreme Court. The Court's decision in that case could, of course, substantially affect the manner in which the federal courts will subsequently address many of the issues discussed in this Article. Over the past six years, the Court also has addressed absolute immunity in several different contexts. See, e.g., Kalina v. Fletcher, $118 \mathrm{~S}$. Ct. 502, 510 (1997) (holding that prosecutors are not absolutely immune from $\$ 1983$ suits when the conduct they are sued for relates to acting as a complaining witness rather than serving a prosecutorial function); Clinton v. Jones, 117 S. Ct. 1636 (1997) (addressing Presidential immunity); Buckley v. Fitzsimmons, 509 U.S. 259 (1993) (concerning prosecutorial immunity); Burns v. Reed, 500 U.S. 478 (1991) (involving prosecutorial immunity). During the current Term, the Court will review a case addressing the scope of legislative immunity. See Bogan v. Scott-Harris, 117 S. Ct. 2430 (1997), granting cert. sub nom. to Scott-Harris v. City of Fall River, No. 95-1950, 1997 U.S. App. LEXIS 594 (1st Cir.Jan. 15, 1997).

3. See 42 U.S.C. $\$ 1983$ (allowing individuals under jurisdiction of United States to commence civil action for deprivation of constitutional or other federal law rights).

4. Ser Bivens, 403 U.S. at 395-96 ("Historically, damages have been regarded as the ordinary remedy for an invasion of personal interests in liberty.").

5. See Wood v. Strickland, 420 U.S. 308, 319-22 (1975) (recognizing that fairness considerations are one factor supporting extension of immunity to school board members). 
they take may lead to a lawsuit. ${ }^{6}$ Finally, the Court believes that the litigation of constitutional torts may impose substantial costs on individual officials and on the government itself, even when the trial court ultimately finds that the officials are not liable. ${ }^{7}$

Although the Court still invokes fairness and overdeterrence justifications for qualified immunity, its recent decisions have transformed the doctrine to emphasize the primary objective of minimizing the social costs of constitutional tort litigation. It has accordingly shaped the doctrine to facilitate early and prompt disposition of qualified immunity claims. ${ }^{8}$ Thus, the Court insists that the central issue of qualified immunity-whether, applying "clearly established" law, the defendant's conduct was "reasonable" under the circumstances-is a question of law. ${ }^{9}$ The Court also pays close attention to the procedural mechanisms for resolving immunity claims, directing lower courts to adjudicate those claims on summary judgment ${ }^{10}$ while cautioning against allowing much, if any, pre-summary judgment discovery. " Moreover, to ensure that qualified immunity is an "immunity from suit," rather than a mere defense to liability, the Court permits officials to pursue interlocutory appeals when trial courts deny their immunity claims. ${ }^{12}$ Part I of this Article explores this doctrinal trend toward emphasizing the social costs rationale for qualified immunity.

While the qualified immunity defense has long been recognized, its application and administration continue to perplex courts ${ }^{13}$ and provoke a substantial amount of scholarly commentary. ${ }^{14}$ The United

6. See Harlow, 457 U.S. at 806-07 (1982) (indicating that without immunity, public officials would be unprotected from undue interference and might not vigorously exercise their official responsibilities).

7. See id. at 814 (identifying litigation expenses and diversion of attention from important public concerns as costs of denying immunity).

8. See Hunter v. Bryant, 502 U.S. 224, 227 (1991) (stating that entitlement to qualified immunity should be determined as quickly as possible).

9. See Elder v. Holloway, 510 U.S. 510, 515-16 (1994); see also Mitchell v. Forsyth, 472 U.S. 511, 526 (1985); Harlow, 457 U.S. at 818.

10. See Harlow, 457 U.S. at 818.

11. See Anderson v. Creighton, 483 U.S. 635,646 n.6 (1987); Harlow, 457 U.S. at 818.

12. See Mitchell, 472 U.S. at 525-27 (recognizing an exception to the final judgment rule for qualified immunity claims). But see Johnson v. Jones, 515 U.S. 304, 313-17 (1995) (holding that Mitchell rule does not apply if trial court's sole reason for denying immunity claim is the existence of a disputed factual issue).

13. See, e.g., Jenkins v. Talladega City Bd. of Educ., 95 F.3d 1036, 1039 (11th Cir. 1996) (noting confusion of district court and defendant about qualified immunity standard), cert. denied, 118 S. Ct. 412 (1997); McMillian v. Johnson, 88 F.3d 1573, 1585 (1lth Cir. 1996) (Propst, $\mathrm{J}$., specially concurring) (acknowledging that keeping up with the law of qualified immunity is a full time job), aff d on other grounds, 117 S. Ct. 1734 (1997); Coffman v. Trickey, 884 F.2d 1057, 1062 (8th Cir. 1989) (noting ongoing confusion as to proper test when addressing qualified immunity disputes).

14. See generally David Achtenberg, Immunily Under 42 U.S.C. $\$ 1983$ : Inlerpretive Approach 
States Supreme Court has repeatedly revisited the doctrine to clarify critical issues surrounding its scope and application. For example, in each of the past three terms, the Court has decided cases addressing the scope of interlocutory appeals available to public officials who are denied qualified immunity in the pretrial stage of constitutional tort litigation. ${ }^{15}$ The Court's review of these procedural issues manifests its recognition of the rampant administrative and docket problems that the high volume of qualified immunity claims generates in the lower courts. Indeed, the necessity for clarity on these issues is hardly unpredictable; in 1995 alone, the federal appellate courts decided 339 cases involving public officials' qualified immunity claims. ${ }^{16}$

To any judge, practitioner, or scholar who has experience with this area of the law, the abundance of qualified immunity appeals should not be surprising. Despite the Court's precautions, the promise of early termination of constitutional tort claims on summary judgment remains illusory. Lower courts struggle with the doctrine's application, finding that, at least in some circumstances, contested factual issues preclude summary judgment. For example, the courts have begun to understand that a factual dispute over a central element of

and the Search for the Legislative Will, 86 Nw. U. L. REv. 497 (1992) (discussing Supreme Court's struggle over proper interpretive approach regarding official immunity under $\$ 1983$ ); Mark $R$. Brown, The Demise of Constiltutional Prospectivily: New Life for Owen?, 79 IOWA L. REv. 273 (1994) (commenting on Supreme Court decisions on governmental immunity); Alan $\mathrm{K}$. Chen, The Ullimate Standard: Qualified Immunity in the Age of Constitutional Balancing Tests, 81 IOWA L. REV. 261 (1995) (discussing choice between rules and standards in regard to immunity doctrine); Kit Kinports, Habeas Corpus, Qualified Immunity, and Crystal Balls: Predicting the Course of Constilulional Law, 33 ARIZ. L. REV. 115 (1991) [hereinafter Kinports, Cryslal Balls] (criticizing Supreme Court rulings involving qualified immunity); Linda Ross Meyer, When Reasonalle Minds Differ, 71 N.Y.U. L. REV. 1467, 1499-1506 (1996) (characterizing qualified immunity as a legal doctrine that acknowledges the indeterminacy of law, yet serves a legitimizing function by taking a positivist approach to law that promotes predictability for public officials); David Rudovsky, The Qualified Immunity Doctrine in the Supreme Court: Judicial Activism and the Restriction of Constitulional Righls, 138 U. PA. L. REV. 23 (1989) (examining qualified immunity under 42 U.S.C. $\$$ 1983). The widespread confusion over the qualified immunity doctrine has even prompted one commentator to lay out the details in a "user's manual." See Karen M. Blum, Qualified Immunily: A User's Manual, 26 IND. L. REv. 187, 190 (1993) [hereinafter Blum, User's Manual] (suggesting article to be used as a "map" to guide judges and lawyers through this area of law).

15. See Johnson v. Fankell, 117 S. Ct. 1800, 1802 (1997) (holding that federal law does not require state courts to permit officials whose qualified immunity claims are denied at the trial court level to pursue an interlocutory appeal); Behrens v. Pelletier, 516 U.S. 299, 313 (1996) (permitting multiple appeals from pretrial orders denying summary judgment on grounds of qualified immunity); Johnson v. Jones, 515 U.S. 304, 316-17 (1995) (holding defendant could not appeal summary judgment order denying qualified immunity based on genuine issue of fact).

16. Citation list on file with The American University Law Review. This figure includes both reported and unreported decisions in which a federal appeals court resolved at least one issue concerning the application of qualified immunity. It does not, of course, include the numerous qualified immunity claims resolved by federal district courts but not appealed. See Chen, supra note 14, at $332 \mathrm{nn} .340-41$ (citing similar statistics for 1992 and 1993). 
the plaintiff's case makes it impossible to resolve a qualified immunity claim. ${ }^{17}$

Dilemmas arising from potential factual disputes also have plagued the courts in cases when the plaintiff alleges a constitutional violation, such as the denial of equal protection, that requires her to prove that the defendant official acted intentionally or with some other requisite state of mind. In these circumstances, the courts often conclude that the defendant's state of mind is a factual issue that must be resolved at trial. ${ }^{18}$

The courts' treatment of immunity claims involving factual disputes suggests that such cases raise special or unique circumstances distinct from the ordinary application of the qualified immunity doctrine, and therefore require carefully tailored exceptions to the general structure of immunity law. That is, the complications created by factual issues under the immunity inquiry are generally viewed by the courts as aberrational.

This Article argues that courts and commentators alike have failed to appreciate that factual issues are an inherent part of the qualified immunity inquiry, notwithstanding the formal designation of qualified immunity as an issue of law. Many of the dilemmas experienced in the understanding and application of the qualified immunity doctrine reflect this fundamental misconception about the role of facts under the doctrine and the possibility of resolution on summary judgment-a misconception perpetuated by the Supreme Court's reluctance to acknowledge this basic conceptual problem.

Part II of this Article explains that factual disputes are inherent in the resolution of qualified immunity because the Court has articulated the qualified immunity doctrine as an open-ended "reasonableness" standard. ${ }^{19}$ As with any reasonableness standard, all qualified immunity inquiries are inevitably fact-dependent, at least in

17. See infra notes $152-86$ and accompanying text.

18. See infra notes $312-22$ and accompanying text.

19. For general discussions concerning the conceptual distinction between bright-line rules and open-ended standards, see FredericK SCHAUER, PLAYiNG BY THE RULES: A Philosophical EXamination of RULE-BASEd DeCision-Making IN LAW AND IN LIFE (1991) (exploring rule-based decision making and examining its relationship with common law). See generally H.L.A. HART, THE CONCEPT OF LAW $124-41$ (2d ed. 1994) (discussing how both precedent and legislation play a role in judicial decisions); MARK KELMAN, A GUIDE TO CRITICAL LEGAL STUDIES 15-63 (1987) (describing incompatibility of mechanical rules and "situation sensitive" standards); Larry Alexander \& Emily Sherwin, The Deceptive Nalure of Rules, 142 U. PA. L. REV. 1191 (1994) (analyzing formulation of rules and their effect on individuals); Duncan Kennedy, Form and Substance in Privale Law Adjudication, 89 HARV. L. REV. 1685 (1976) (discussing application and formulation of standards and rules in law); Pierre Schlag, Rules and Standards, 33 UCLA L. REv. 379 (1985) (examining interplay between standards and rules in law). 
part, because the reasonableness of a government official's conduct must be evaluated with reference to some set of facts. ${ }^{20}$ Courts can assess whether a particular act violates a "clearly established" right only by comparing the existing case law to an undisputed description of that act. Entitlement to qualified immunity, therefore, must be viewed as a mixed question of law and fact. ${ }^{21}$

The difficulty of resolving qualified immunity claims under this reasonableness inquiry is compounded by the Court's increasing tendency to define substantive constitutional doctrine by open-ended standards or "balancing" tests, which require courts to weigh "individual liberties (privacy, equality, speech) against government interests (public health, social welfare, social order) in each particular case." ${ }^{22}$ Under such a balancing regime, the law that defines the underlying violation of the plaintiff's rights in a constitutional tort case is, like the immunity inquiry, highly fact-dependent and casespecific. Applying qualified immunity in the age of constitutional balancing tests creates "stacked" or dual reasonableness standards.

20. See Anderson v. Creighton, 483 U.S. 635, 641 (1987) (explaining that in determining reasonableness, one must evaluate facts surrounding incident).

21. For an examination of the conceptual issues involving treating issues as factual, legal, or mixed questions, see infra notes 547-65 and accompanying text.

22. Chen, supra note 14, at 265 (noting Supreme Court's preference for standards under substantive constitutional doctrine); infra notes 272-301 and accompanying text. This author has argued elsewhere that the confluence of these two open-ended legal standards-the immunity standard and substantive constitutional standards-creates tremendous theoretical difficulties with immunity doctrine and substantive constitutional law. See Chen, supra note 14, at 267 (indicating that decisions regarding rules and standards in immunity cases affect other elements of constitutional law). This Article, in contrast, demonstrates the tremendous practical disadvantages and doctrinal complications generated by the qualified immunity standard.

The conceptual problems that I have identified with the "stacking" problem-that is, the theoretical and doctrinal difficulties that arise when the law incorporates a legal "standard" at two distinct analytical levels-may now also affect federal constitutional rights as adjudicated under federal habeas corpus law. Congress recently adopted an amendment to the federal statutes governing habeas jurisdiction that limits a federal court's power to overturn state court criminal convictions to circumstances where the state court's ruling "resulted in a decision that was contrary to, or involved an unreasonable application of, clearly established federal law, as determined by the Supreme Court of the United States." 28 U.S.C. $\$ 2254$ (d)(1). This section appears to require that federal courts must assess the reasonableness of a state court's application of constitutional principles set forth by the Supreme Court, which necessarily will also entail an assessment of the underlying constitutional balancing test. See Lindh v. Murphy, 96 F.3d 856, 870 (7th Cir. 1996) (“[W]hen the dispute lies not in the meaning of the Constitution, but in its application to a particular set of facts-when it is, in the standard phrase, a "mixed question of law and fact' $-\$ 2254$ (d) (1) restricts the grant of collateral relief to cases in which the state's decision reflects 'an unreasonable application of the law."), rev'd on other grounds, $117 \mathrm{~S}$. Ct. 2059 (1997). Bul cf. Larry W. Yackle, A Primer on the New Habeas Corpus Stalule, 44 BuFf. L. REv. 381, 403-07 (1996) (arguing both as a normative and descriptive matter that Congress did not intend to adopt an official immunity model for reviewing state court criminal convictions under $\$ 2254(\mathrm{~d})(\mathrm{i}))$.

23. See Chen, supra note 14, at 267, 308-09; see also Anderson, 483 U.S. at 643-44 (noting possibility of reasonably unreasonable conduct under qualified immunity, but disregarding concern as semantic coincidence). 
Thus, an official's reasonableness must be examined with reference not only to the facts, but also with respect to two conceptually distinct legal frameworks-one grounded in substantive constitutional law, and one derived from the law of qualified immunity. The predominance of constitutional balancing tests increases the likelihood of factual conflicts.

Part III of this Article describes how, at the same time that the Court's qualified immunity doctrine evolved, there was a parallel movement under federal summary judgment law to increase the availability of pretrial termination of litigation. ${ }^{24}$ Specifically, the Court has eased the burdens on parties seeking summary judgment under Rule 56 of the Federal Rules of Civil Procedure. Most pertinent to a proper understanding of qualified immunity, the Court has underscored that a critical component of summary judgment analysis is whether the moving or non-moving party bears the burden of persuasion on the claim being adjudicated. ${ }^{25}$

Part IV of this Article identifies how the intersection of a fact-based qualified immunity doctrine and summary judgment law generates significant conceptual problems. Recognition of the inherent factual nature of "qualified" immunity may assist courts, policymakers, and scholars in understanding, implementing, and perhaps reforming the doctrine. First, greater appreciation of qualified immunity's factual nature may explain the substantial doctrinal confusion about the application of conventional summary judgment standards to the qualified immunity defense. ${ }^{26}$ Although the laws of summary judgment and qualified immunity have similar gatekeeping objectives, they conflict in significant, but unrecognized, ways. Instead of acknowledging the conceptual incompatibility of qualified immunity and summary judgment, the courts have expended much energy trying to make them compatible. This ill-conceived effort has served

24. See Anderson v. Liberty Lobby, Inc., 477 U.S. 242, 251 (1986) (holding that courts should evaluate motions for summary judgment with regard to the applicable standard of proof on the underlying claim); Celotex Corp. v. Catrett, 477 U.S. 317, 322-23 (1986) (holding termination by summary judgment appropriate where plaintiff failed to establish essential element of case after discovery was permitted).

25. See Celotex, 477 U.S. at 322-25.

26. This confusion is reflected by the Court's disagreement over the appropriate summary judgment standard for qualified immunity claims in Hunter v. Byant, 502 U.S. 224 (1991). See $i d$. at 228-29 (discussing summary judgment standard in context of qualified immunity claims); id. at 229 (Scalia, J., concurring in the judgment) (disagreeing with Court's assessment of summary judgment standard); id. at 229 (Stevens, J., dissenting) (disagreeing with Court's assessment of summary judgment standard); $i d$. at 234 (Kennedy, J., dissenting) (noting substantial disagreement among the Justices about proper summary judgment standard). For an extensive discussion relating the continuing confusion that Hunter has created, compare Act Up!/Portland v. Bagley, 988 F.2d 868, 872-73 (9th Cir. 1992), with id. at 879-82 (Norris, J., dissenting from denial of rehearing en banc). 
only to perpetuate widespread confusion about procedural questions critical to the application of the doctrine.

Because of its factual nature, qualified immunity is a hybrid form of immunity that presents unique challenges in formulating a meaningful procedural device for its resolution. The Court insists that qualified immunity is an immunity from suit, ${ }^{27}$ not simply a defense to liability. But to the extent this is the case, summary judgment is an inappropriate procedural vehicle for advancing the qualified immunity doctrine's purposes, because summary judgment can generally provide only immunity from trial. The hybrid nature of qualified immunity also explains why the courts have been confused about other procedural issues related to administration of pretrial litigation, such as the availability and scope of discovery and the permissible role for the jury in assessing factual disputes underlying the immunity inquiry. It also illustrates why the federal courts have been unable to formulate a coherent analytical framework for addressing qualified immunity; the immunity doctrine simply does not comport with the traditional understanding and operation of summary judgment procedures. The confusion surrounding each of these issues can be partly attributed to a failure to acknowledge the central role of facts in the qualified immunity analysis.

Second, the factual element of the immunity reasonableness analysis has thus far confounded the courts in their attempts to identify which party bears the burden of persuasion on the issue of qualified immunity for purposes of both summary judgment and trial. Neither the Supreme Court nor the lower courts has provided a coherent explanation of the parties' evidentiary burdens in the adjudication of immunity claims. ${ }^{2 x}$ This unfortunate omission is critical, for the application of the summary judgment doctrine is entirely contingent upon the allocation of the burden of persuasion on the issue being litigated. Perhaps the allocation of the burden of persuasion to either party can never make sense in this area of law, yet thus far the courts have avoided even acknowledging this issue as a problem.

Finally, Part $\mathrm{V}$ of this Article identifies how the factual nature of qualified immunity provides a doctrinal explanation for the increasing burden facing lower federal courts that must regularly address qualified immunity. To the extent that factual issues are inherent, qualified immunity claims will seldom be determined on summary

27. See Mitchell v. Forsyth, 472 U.S. 511,526 (1985).

28. See Kit Kinports, Qualified Immunity in Section 1983 Cases: The Unanswered Questions, 23 GA. L. REv. 597, 634-42 (1989) [hereinafter Kinports, Unanswered Questions]. 
judgment at the earliest possible stage of the lawsuit, ${ }^{29}$ at least if the courts are properly applying the Supreme Court's standard. Thus, public official defendants may commonly undergo the burdens of litigation, and even trial, never achieving the early and expeditious resolution the Court has envisioned.

The open-ended nature of the immunity standard causes a paradoxical effect. Originally designed to alleviate the social costs of constitutional tort litigation, qualified immunity instead has institutionalized a cumbersome and costly system for resolving constitutional tort claims. This creates the ultimate irony: a doctrine specifically designed to alleviate the social costs of constitutional tort litigation may in fact have the opposite effect. The qualified immunity doctrine and the litigation surrounding its application may actually be increasing the social costs of these cases, creating what can be called "secondary burdens," the social costs associated with litigating immunity questions themselves. Empirical evaluation of these costs may lead the courts to reassess the doctrine's policy ramifications.

\section{QUALIFIED IMMUNITY AS GATEKEEPER}

The law generally recognizes the availability of damages relief when a federal, state, or local public official violates a person's constitutional rights. Under the Supreme Court's holding in Bivens $v$. Six Unknown Named Agents of Federal Bureau of Narcotics, ${ }^{30}$ injured persons can sue federal officials directly under the Constitution. ${ }^{31}$ Those injured by state or local officials may seek relief under 42 U.S.C. $\S$ $1983 .^{32}$ Under both of these causes of action, a plaintiff may recover for the deprivation of a wide range of constitutional rights, so long as she can prove that the right exists, ${ }^{33}$ that the defendant violated the

29. See Alan K Chen, Burns v. Reed-Narrowing the Prosecutor's Protection from Liability for Unconstitutional Conduct, 3 POLICE MisConduct \& CIV. RTS. LAW REP. 121, 125-26 (1991) ("Courts are not always able to resolve summary judgment motions raising qualified immunity claims because of factual disputes.").

30. 403 U.S. 388 (1971).

31. See id. at 389.

32. The statute provides that:

Every person who, under color of any statute, ordinance, regulation, custom, or usage, of any State ... subjects, or causes to be subjected, any citizen of the United States or other person within the jurisdiction thereof to the deprivation of any rights, privileges, or immunities secured by the Constitution and laws, shall be liable to the party injured in an action at law, suit in equity, or other proper proceeding for redress.

42 U.S.C. $\S 1983$ (1994). For an interesting examination of whether $\S 1983$ should even be necessary to enforce constitutional claims, see Susan Bandes, Reinventing Bivens: The SelfExeculing Constitution, 68 S. CAL. L. REv. 289 (1995).

33. See Siegert v. Gilley, 500 U.S. 226, 232 (1991) (indicating courts must determine "whether the plaintiff has asserted a violation of a constitutional right at all"); Gomez v. Toledo, 446 U.S. 635,640 (1980) (stating that $\$ 1983$ plaintiff must allege deprivation of a federal 
right under color of governmental authority, ${ }^{34}$ and that the defendant's acts proximately caused a cognizable harm. ${ }^{35}$

The constitutional tort remedy furthers important values by compensating individuals harmed by unconstitutional official conduct and by deterring public officials from engaging in future infractions. $^{36}$ It also recognizes the importance of constitutional rights and affirms respect for moral principles. ${ }^{37}$

For more than a generation, however, the Supreme Court has struggled to balance these benefits against competing social policy concerns implicated by the availability of monetary remedies against public officials for constitutional injuries. ${ }^{38}$ These policy considera-

right).

34. Under $\$ 1983$, an official must have acted under color of state law. See Monroe v. Pape, 365 U.S. 167, 183-87 (1961), ovemuled on other grounds by Monell v. Department of Soc. Servs., 436 U.S. 658 (1978). In a Bivens action, the official must have acted under color of federal authority. See Bivens, 403 U.S. at 389.

35. See Gomen, 446 U.S. at 638-40. But see Memphis Community Sch. Dist. v. Stachura, 477 U.S. 299, 307 (1986) (holding that damages may be awarded for deprivations of rights only if the deprivation results in actual harm); Carey v. Piphus, 435 U.S. 247, 263-64 (1978) (holding that compensable injury must result directly from denial of constitutional right).

36. The Court has focused on compensation as the principal objective of the constitutional tort action. See Felder v. Casey, 487 U.S. 131, $139-40$ (1988) (describing compensation as a main objective of $\$ 1983$ actions); Harlow v. Fitzgerald, 457 U.S. 800, 814 (1982) (stating that damages relief "may offer the only realistic avenue for vindication of constitutional guarantees") (citations omitted); Bivens, 403 U.S. at 410 (Harlan, J., concurring) (describing central role of damages in actions brought directly under the Constitution). The Court does, however, consider the deterrent effect of both compensatory and punitive damages. See generally Smith v. Wade, 461 U.S. 30,36 n.5 (1983).

37. See, e.g., Peter W. LOW \& JOHN CALVin Jefreies, JR., Civil Rights Actions 42, 49-50 (1988) (describing how damage awards are one way of affirming legal rights, thereby educating moral sentiments of community); PETER H. SCHUCK, SUING GOVERNMENT: CITIZEN REMEdieS FOR OFFICIAL WRONGS 16 (1983) (arguing that a primary goal of constitutional tort remedies is to "exemplify society's moral principles"); Christina Whitman, Constitutional Torls, $79 \mathrm{MrCH}$. L. REv. 5, 23-25 (1980) (indicating that $\$ 1983$ 's assurance of a federal forum serves important symbolic goals about the importance of federal rights); $(f$. Steven $\mathrm{D}$. Smith, The Critics and the "Criss": A Reassessment of Current Conceplions of Tort Law, 72 CORNELL L. REv. 765, 766 (1987) (arguing that tort law's primary function is not compensation or deterrence, but the affirmation of norms).

38. See generally Harlow, 457 U.S. at 814 (asserting that qualified immunity was the "best attainable accommodation" of the competing values at stake in constitutional tort actions); Ronald A. Cass, Damage Suils Against Public Officers, 129 U. PA. L. REv. 1110, 1133-53 (1981) (describing model for determining proper scope of qualified immunity in terms of balancing deterrent function of constitutional tort liability against systemic social costs of system that holds officials accountable for their unconstitutional conduct). Numerous commentators have recognized that qualified immunity is premised on policy grounds, notwithstanding the Court's attempt to characterize its decisions as an exercise in statutory interpretation or focus on historical considerations. See, e.g., Jack M. Beermann, A Crilical Approach to Section 1983 with Special Allenlion to Sources of Law, 42 STAN. L. REV. 51, 67 (1989) (arguing that the Court's policymaking is "nowhere more clear than in the immunities area, where the early reliance on 1871 common law has given way to a body of law that can be accurately characterized as a pure federal common law of immunities"); Kinports, Cyystal Balls, supra note 14, at 120-21, 197 \& n.32 (arguing that the Court recognizes the qualified immunity defense as a "creature of policy" rather than a matter of statutory interpretation); Rudovsky, supra note 14, at 36 (maintaining that Court's "policy judgment" substantially defines qualified immunity). Nonetheless, even 
tions have led the Court to establish official immunities that substantially limit plaintiffs' rights to recover under Bivens and $\S 1983$. $^{39}$ Immunity law arises from the Court's general fear that public officials may be particularly susceptible to suits for constitutional violations because the nature of their positions exposes them to frequent contact with members of the public.

The Court has established two separate immunity doctrinesabsolute immunity and qualified immunity-to mitigate the potential problems it associates with constitutional tort liability. Limited classes of officials, such as legislators, ${ }^{40}$ prosecutors, ${ }^{41}$ and judges, ${ }^{42}$ are entitled to absolute immunity, which categorically bars any constitutional tort action against such officials when they are sued for actions taken in the course of their official functions. Officials entitled to absolute immunity are not subject to suit for any official act, even if done maliciously or intentionally. ${ }^{43}$ Despite the breadth of this immunity, the Court has categorically forbidden actions against these classes of officials in order to prevent them from being burdened by an onslaught of civil rights actions. ${ }^{44}$ Because of its categorical

members of the Court have moments of candor. See Wyatt v. Cole, 504 U.S. 158, 170-71 (1992) (Kennedy, J., concurring) (acknowledging that the Court has transformed qualified immunity from a doctrine based on historical common law practices to one dictated by policy concerns).

39. Numerous other barriers to obtaining relief for constitutional violations exist as well. See, e.g., 28 U.S.C. $\$ 2254$ (d) (1) (limiting federal habeas corpus relief to cases where the state court adjudication of a criminal defendant's claims "resulted in a decision that was contrary to, or involved an unreasonable application of, clearly established Federal law, as determined by the Supreme Court of the United States"); Teague v. Lane, 489 U.S. 288, 311 (1989) (plurality opinion) (holding that habeas corpus petitioners may not seek relief based on a "new" constitutional rule unless it fits one of two narrow exceptions to non-retroactivity of constitutional rules to collateral proceedings); Schweiker v. Chilicky, 487 U.S. 412,423 (1988) (refusing to recognize Bivens action for procedural due process violations under Social Security Act disability provisions where Congress had created independent remedial scheme to restore benefits); City of Los Angeles v. Lyons, 461 U.S. 95, 101 (1983) (narrowing standing requirements for plaintiffs seeking prospective injunctive relief against unconstitutional conduct); Monell v. Department of Soc. Servs., 436 U.S. 658, 694 (1978) (holding that local government bodies are liable under $\$ 1983$ only if the local official causing the constitutional harm was acting pursuant to an official "policy or custom").

40. The Court first recognized some form of immunity for public officials in Tenney $v$. Brandhove, 341 U.S. $367,372-76$ (1951) (holding that state legislators are entitled to absolute immunity from constitutional tort actions).

41. See Imbler v. Pachtman, 424 U.S. 409, 431 (1976) (holding that prosecutors are entithed to absolute immunity from civil suits under $\$ 1983$ ).

42. See Pierson v. Ray, 386 U.S. 547, 553-55 (1967) (holding that judges are entitled to absolute immunity for acts relating to their official role). Congress recently amended $\S 1983$ to codify judicial immunity from injunctive relief as well. See Federal Courts Improvement Act of 1996, Pub. L. No. 104-317, 1996 U.S.C.C.A.N. (110 Stat.) 3847 (codified as amended at 42 U.S.C. $\S \S 1983,1988)$.

43. See Pierson, 386 U.S. at 554.

44. See id. (speculating that judges would be sued frequently in absence of immunity because of nature of their duties and inevitable dissatisfaction of losing litigants). 
nature, the absolute immunity defense is often asserted and resolved on the pleadings. ${ }^{45}$

The vast remainder of officials, who comprise the most substantial segment of the public sector, are entitled to a more limited "qualified" immunity. ${ }^{46}$ Qualified immunity protects public officials from financial liability and, theoretically, from the burdens of litigation, as long as the unconstitutional conduct they are charged with "does not violate clearly established ... constitutional rights of which a reasonable person would have known." ${ }^{47}$ Unlike absolute immunity, which establishes a categorical bar to suits against certain types of officials, qualified immunity requires a case-by-case analysis of individual officials' actions in particular factual settings.

45. See Imbler, 424 U.S. at 419 n.13 ("An absolute immunity defeats a suit at the outset, so long as the official's actions were within the scope of the immunity."). Factual issues concerning scope of immunity do occasionally arise in absolute immunity cases. See infra note 571 and accompanying text.

46. See Sheldon H. Nahmod, Constitutional Wrongs Without Remedies: Executive Official Immunily, 62 WASH. U. L.Q. 221, 221 (1984) (stating that "most" state and federal executive officials are covered by qualified immunity).

47. Harlow v. Fitzgerald, 457 U.S. 800, 818 (1982) (citations omitted). The Supreme Court has held that the immunity doctrines should be applied identically in both $\$ 1983$ actions and Bivens actions. See Butz v. Economou, 438 U.S. 478, 500 (1978). The matter of what sources of law to examine when determining whether a constitutional right is "clearly established" has been the subject of some controversy, but is beyond the scope of this Article. For a recent discussion of the different approaches courts have used and a proposal that federal courts should also look to state court decisions in ascertaining whether law is clearly established, see Richard B. Saphire, Qualified Immunity in Section 1983 Cases and the Role of State Decisional Law, 35 ARiz. L. REv. 621, 627-32, 643-59 (1993). Recent developments in two closely related areas of law-federal habeas corpus jurisdiction and criminal civil rights prosecutionsdemonstrate an interesting contrast in this regard. In 1996, Congress enacted the Antiterrorism and Effective Death Penalty Act, which modified habeas corpus jurisdiction by limiting a federal court's power to overturn state court criminal convictions to circumstances where the state court's ruling "resulted in a decision that was contrary to, or involved an unreasonable application of, clearly established Federal law, as determined by the Supreme Court of the United States." 28 U.S.C. $\$ 2254$ (d) (1). The new habeas statute thus "explicitly identifies only the Supreme Court as the font of "clearly established' rules." Lindh v. Murphy, 96 F.3d 856, 869 (7th Cir. 1996), rev'd on other grounds, 117 S. Ct. 2059 (1997). In contrast, the Supreme Court took a different approach in a recent decision interpreting the scope of 18 U.S.C. $\$ 242$ (1994). Section 242 makes it a federal crime for a person acting under color of law to willfully deprive a person of "any rights, privileges, or immunities secured or protected by the Constitution or laws of the United States." 18 U.S.C. \$242. In Uniled States v. Lanier, 117 S. Ct. 1219 (1997), a state judge who was convicted under $\S 242$ for sexually assaulting several women argued that he lacked sufficient notice or "fair warning" that such conduct was a violation of federal constitutional law. See id. at 1223. The Court denied his claim and rejected the Sixth Circuit's decision to strike down his convictions on the ground that "fair warning" for due process purposes required that there be a decision by the United States Supreme Court that had previously declared such conduct, or very factually similar conduct, to be a constitutional violation. See id. Analogizing to qualified immunity claims in civil rights cases, the Court held that sufficient warning about the definition of constitutional rights could also be derived from lower court decisions. See id. at 1226.

48. See Chen, supra note 14, at 291-92 (describing qualified immunity test as a contextsensitive standard). 
Qualified immunity is premised on the notion that extensive exposure to constitutional tort suits imposes several potential costs on both the official defendants and American society. First, the Court has relied on a fairness argument. This argument suggests that it is unfair to punish public officials for exercising their discretionary functions in manners that may ultimately result in financial liability, particularly when the boundaries of constitutional law are often difficult to identify. ${ }^{49}$ Second, the Court has contended that public officials' fear of financial liability for conduct that violates the Constitution may significantly inhibit them not only from committing unconstitutional acts, but also from lawful performance of their duties. That is, public officials will second-guess their own actions in a manner that will interfere with performance of important public functions, such as law enforcement or school administration. ${ }^{50}$ Finally, the Court has speculated that subjecting public officials to constitutional tort litigation will impose costs on individual officials, government, and consequently, all of society. ${ }^{51}$ This "social costs" argument is premised on the Court's speculation that many constitutional tort claims are frivolous. ${ }^{53}$ Accordingly, the litigation process itself is said to impose substantial burdens on public officials who must defend themselves, regardless of whether those officials are ultimately held to be financially liable for their allegedly unconstitutional conduct.

In a series of qualified immunity decisions spanning the past thirty years, the Supreme Court has continued to formally recognize these three independent concerns-fairness, overdeterrence, and social costs-that it associates with constitutional tort litigation. As a brief survey of these decisions reveals, ${ }^{54}$ however, the Court has trans-

49. See Wood v. Strickland, 420 U.S. 308, 319-22 (1975); Piesson, 386 U.S. at 555-57; see also Chen, supra note 14 , at 273 (noting that qualified immunity is designed to protect officials "who are not good issue spotters").

50. See, e.g., Anderson v. Creighton, 483 U.S. 635, 638 (1987) (arguing that permitting damage suits creates risk that fear of "personal monetary liability and harassing litigation" will unduly inhibit government officials in discharging their duties); Harlow, 457 U.S. at 814 (stating that fear of lawsuits would dampen willingness of officials to discharge their duties); Wooch 420 U.S. at 319-20 (stating that denying immunity to school officials would deter them from exercising independent judgment in the best interests of the school and students).

51. See Harlow, 457 U.S. at 814.

52. Unfairly imposing financial liability on public officials and overdeterring such officials from performing the socially beneficial aspects of their jobs could also be characterized as "social costs." This Article uses the term "social costs" to refer primarily to costs associated with constitutional tort litigation, as opposed to constitutional tort liability.

53. See Harlow, 457 U.S. at 814 (asserting that constitutional tort claims "frequently run against the innocent as well as the guilty").

54. For more comprehensive discussions of the Supreme Court's qualified immunity cases, see Nahmod, supra note 46, at 224-31 (describing development of qualified immunity doctrine in the Supreme Court); Rudovsky, supra note 14, at 35-73 (discussing Supreme Court's 
formed modern qualified immunity doctrine to focus primarily on reducing the social costs of constitutional tort litigation. In particular, the Court has paid increasing attention to procedural mechanisms for early termination of constitutional tort claims and has consistently avoided issues relating to the inherently factual nature of qualified immunity.

\section{A. The Court's Early Emphasis on Faimess and Overdeterrence}

The Court's qualified immunity jurisprudence began with a focus on the fairness and overdeterrence rationales. These justifications had their roots in the historical basis for public officials' immunity at common law, which, as the Court observed:

[A]pparently rested, in its genesis, on two mutually dependent rationales: (1) the injustice, particularly in the absence of bad faith, of subjecting to liability an officer who is required, by the legal obligations of his position, to exercise discretion; (2) the danger that the threat of liability would deter his willingness to execute his office with the decisiveness and the judgment required by the public good. ${ }^{55}$

The Court emphasized the fairness rationale in two of its early qualified immunity decisions, Pierson v. Ray ${ }^{56}$ and Wood v. Strickland. ${ }^{57}$ Pierson, the Court's first qualified immunity decision, involved civil rights claims brought by a group of clergymen who had refused to comply with racial segregation rules at a Mississippi bus terminal. ${ }^{58}$ The plaintiffs were arrested and convicted under a state statute that prohibited congregating in a public place under circumstances that caused a breach of the peace. ${ }^{59}$ After the convictions were either overturned or dismissed, the plaintiffs filed a $\S 1983$ suit, claiming that the arresting officers and the trial judge had deprived them of their constitutional rights, as well as their common law rights against false arrest and imprisonment. ${ }^{60}$ The Mississippi breach of peace statute under which the plaintiffs were convicted had since been held facially unconstitutional in a separate case. ${ }^{61}$

qualified immunity decisions); see also 2 SHELdON H. NAHMOD, Civil Rights AND Civil LIBERTIES LITIGATION: THE LAW OF SECTION $1983 \$ \$ 8.01-8.21$ (3d ed. 1991) (analyzing qualified immunity as an affirmative defense).

55. Scheuer v. Rhodes, 416 U.S. 232, 240 (1974) (emphasis added) (internal citations omitted).

56. 386 U.S. 547 (1967).

57. 420 U.S. 308 (1975).

58. See Pierson, 386 U.S. at 549.

59. See id.

60. See id. at 550.

61. See id. The Court found the Mississippi code unconstitutional in Thomas v. Mississippi, 380 U.S. 524, 524 (1965). 
Pierson extended the common law good faith immunity for police officers, which had previously applied to false arrest and imprisonment actions, to constitutional tort claims. ${ }^{62}$ The Court's principal rationale for conferring qualified immunity to police officers was to alleviate the tension between the officers' law enforcement duties and their obligation to comply with the Constitution. ${ }^{63}$ The Court emphasized the unfairness of placing police officers between the proverbial rock and a hard place in such situations. ${ }^{64}$

Similarly, in Wood, the Court used fairness to justify extending qualified immunity to school board officials for decisions made in the context of pursuing disciplinary actions against students. ${ }^{65}$ In that case, several students argued that the defendants expelled them without procedural due process. ${ }^{66}$ In rejecting the students' claim on immunity grounds, the Court held that it would be unfair to burden school officials with liability for actions "found subsequently" to have deprived the student of a constitutional right. ${ }^{67}$ The Court's obvious concern in Wood was with the level of uncertainty faced by public officials in assessing whether their conduct violates constitutional law. ${ }^{68}$ The Court has relied on similar fairness arguments to extend qualified immunity to public officials in several other contexts. ${ }^{69}$

In both Wood and Scheuer $v$. Rhodes, ${ }^{70}$ the Court expanded the policy rationales underlying qualified immunity to include concerns about overdeterrence. ${ }^{71}$ The Court focused on the overdeterrence analysis in Scheuer, in which a state governor and other high-level state executive officials were sued for their role in ordering National Guard

62. See Pierson, 386 U.S. at 557.

63. See id. at 555.

64. See id. ("A policeman's lot is not so unhappy that he must choose between being charged with dereliction of duty if he does not arrest when he has probable cause, and being mulcted in damages if he does.").

65. See Wood v. Strickland, 420 U.S. 308, 319 (1975).

66. See id. at 310 .

67. See id. at 319.

68. See id. at 319-21. Nevertheless, the dissenting Justices in Wood felt that the majority's decision was still unfair to public school officials, arguing that charging public school officials with knowledge of the law, even reasonable knowledge of clearly settled law, would impose an unfair burden. See id. at 329 (Powell, J., dissenting).

69. See Harlow v. Fitzgerald, 457 U.S. 800,818 (1982) (extending immunity to high-level presidential aides for their discharge of a Defense Department official allegedly motivated by the latter's disclosure of cost overruns on a defense project); Procunier v. Navarette, 434 U.S. $555,562-66(1978)$ (extending immunity to state prison officials for depriving a prisoner of First Amendment and due process rights by allegedly interfering with his ability to send correspondence); O'Connor v. Donaldson, 422 U.S. 563, 577 (1975) (extending immunity to a state hospital administrator for alleged deprivations of liberty caused by the institutionalization of a patient).

70. 416 U.S. 232 (1974).

71. The Court in Pierson discussed the chilling effect of constitutional tort liability, but only in the context of absolute judicial immunity. See Pierson v. Ray, 386 U.S. 547, 554 (1967). 
troops to control a student demonstration at Kent State University. ${ }^{72}$ After the troops shot and killed four students during the demonstration, the students' families filed a constitutional tort claim asserting that the defendants' actions in authorizing the use of troops deprived the students of their constitutional due process rights. ${ }^{73}$ Scheuer held that, depending on the facts, the defendants might be entitled to qualified immunity. ${ }^{74}$ In doing so, the Court articulated the basis of the overdeterrence argument in some detail:

Public officials... who fail to make decisions when they are needed or who do not act to implement decisions when they are made do not fully and faithfully perform the duties of their offices. Implicit in the idea that officials have some immunity-absolute or qualified-for their acts, is a recognition that they may err. The concept of immunity assumes this and goes on to assume that it is better to risk some error and possible injury from such error than not to decide or act at all. ${ }^{75}$

The Court also used this reasoning in Wood, concluding that school board members would be overdeterred in pursuing their legitimate duties in the discipline process if immunity were not extended to them. $^{76}$ Denying immunity to school officials, the Court argued, would deter them from exercising independent judgment in the best interests of the school and students. ${ }^{77}$ Subsequent cases have invoked the overdeterrence rationale in recognizing qualified immunity for other types of public officials as well. ${ }^{78}$

\section{B. The Transformation of Qualified Immunity}

In 1982, the Court decided Harlow v. Fitzgerald, ${ }^{79}$ signaling, a major doctrinal shift in qualified immunity law that reflected the evolution of the Court's policy rationales to emphasize freeing public officials from the burdens of constitutional tort litigation. While fairness and

72. See Scheuer, 416 U.S. at 232.

73. See id. at 235.

74. See id. at 247.

75. Id. at 241-42 (internal citations omitted).

76. See Wood v. Strickland, 420 U.S. 308, 319-20 (1975).

77. See id.

78. See Anderson v. Creighton, 483 U.S. 635, 638 (1987) (recognizing overdeterrence rationale for immunity for FBI agent executing warrantless search of a home); Procunier $v$. Navarette, 434 U.S. 555, 562-63 (1978) (extending immunity to prison officials and officers charged with violating prisoners' First Amendment privilege to send and receive mail based on overdeterrence justification).

79. 457 U.S. 800 (1982). Harlow was the companion case to Nixon v. Filzgerald, 457 U.S. 731, 757-58 (1982), in which the Court extended absolute immunity for constitutional torts to the President, at least for actions taken within the scope of his official duties while in office. $C f$. Clinton v. Jones, 117 S. Ct. 1636, 1639 (1997) (denying temporary litigation immunity to a sitting U.S. President for unofficial actions allegedly undertaken before he took office). 
overdeterrence still play a formal role in the Court's immunity jurisprudence, their function as the driving force behind qualified immunity was severely diminished after Harlow.

In Harlow, the plaintiff, A. Ernest Fitzgerald, a civilian Air Force official, brought a Bivens action against two of President Nixon's closest aides, Bryce Harlow and Alexander Butterfield. ${ }^{80}$ The thrust of Fitzgerald's claim was that Harlow and Butterfield violated his First Amendment rights when they conspired to fire him in retaliation for his disclosure of major cost overruns on a Defense Department project at a widely publicized congressional hearing. ${ }^{81}$ Fitzgerald offered evidence from which he argued that a conspiracy to deprive him of his constitutional rights could reasonably be inferred. ${ }^{82}$ In response, Harlow argued that there were legitimate reasons for terminating Fitzgerald, that he had no reason to believe a conspiracy existed, and that he acted in good faith. ${ }^{83}$ Butterfield argued that he was not involved in the decision to fire Fitzgerald and that he never communicated his views to any Defense Department officials who would have been responsible for the termination. ${ }^{84}$ Both defendants argued that, despite several years of discovery, Fitzgerald had not uncovered sufficient evidence that they engaged in any constitutional violation. ${ }^{85}$

The trial court rejected the defendants' summary judgment motion, concluding that Fitzgerald had adequately pleaded a Bivens claim, and that genuine issues of material fact precluded pretrial resolution of his claims. ${ }^{86}$ After the court of appeals dismissed the defendants' appeal, the Supreme Court granted certiorari to determine the extent of immunity available to high-level presidential aides. ${ }^{87}$ In its opinion, however, the Court did much more than define the scope of qualified immunity for this class of officials. ${ }^{88}$ Instead, it completely reformulated the test under which all qualified immunity claims should be examined.

80. See Harlow, 457 U.S. at 802-05. low).

81. See Nixon, 457 U.S. at 733-36 (describing facts involving same conspiracy at issue in Har-

82. See Harlow, 457 U.S. at $802-05$.

83. See id. at 803-04.

84. See id. at 805 .

85. See id. at 803-05.

86. See id. at 805-06.

87. See id. at 806 .

88. The Court previously had examined qualified immunity in a context-specific manner in which it accommodated several different factors depending upon the type of official involved. See Scheuer v. Rhodes, 416 U.S. 232, 247 (1974) (defining immunity based on variable factors such as an official's responsibilities, the scope of her discretion, and the totality of the circumstances at the time). See generally Chen, supra note 14, at 289 (noting shift in Court's immunity jurisprudence from a different standard for particular types of officials to a unitary reasonableness standard). 
The Court recognized that the defendants should be entitled to assert a qualified immunity defense, ${ }^{89}$ again voicing its concerns about fairness $^{90}$ and overdeterrence. ${ }^{91}$ In addition, however, the Court introduced and emphasized several new policy considerations associated with the litigation burdens that constitutional tort claims impose on public officials and society.

The Court identified several general social costs likely to be incurred under a system that allowed unlimited exposure to constitutional tort litigation: (1) an increase in the government's litigation expenses; (2) the diversion of public officials' attention and energy away from performing their duties and toward defending lawsuits; and (3) the deterrence of able people willing to occupy public office. ${ }^{12}$ The Court anticipated that these costs were likely to be substantial, considering its assumption that many constitutional tort claims lack merit. ${ }^{93}$ Thus, the Court noted that an important element of the immunity doctrine must be a procedure that would alleviate these costs by permitting " [i] nsubstantial lawsuits [to] be quickly terminated."'

The Court's concern for prompt and early termination of constitutional tort claims led to its reformulation of the qualified immunity standard. Early termination would be unlikely under the test established by the Court's earlier immunity decisions. In Wood v. Strickland ${ }^{95}$ the Court had articulated a qualified immunity test that included both a "subjective" and an "objective" component. Under the subjective component, qualified immunity would not protect an offi-

89. The Court rejected the defendants' claim that they were entitled to some sort of derivative absolute immunity because of their close working relationship with the President. See Harlow, 457 U.S. at 807-13.

90. See id. at 818 (noting unfairness of charging officials with responsibility to know law that has not yet been clearly decided). The fairness argument is located in the Court's discussion of the justifications for the objective reasonableness standard, rather than in its list of general policy reasons for immunity. See id. at 814 .

91. See id. (noting that fear of constitutional tort suits may "dampen the ardor of all but the most resolute, or the most irresponsible [public officials], in the unflinching discharge of their duties." (quoting Gregoire v. Biddle, I77 F.2d 579, 581 (2d Cir. 1949))) (alteration in original).

92. See id. As several commentators have observed, there is no empirical basis for any of the Court's underlying assumptions about the necessity for qualified immunity. See, e.g., Beermann, supra note 38, at 94-97; Gildin, supra note 1, at 389-90 \& nn.89-90 (1989); Nahmod, supra note 46, at 221, 248; Peter H. Schuck, Suing Our Servants: The Courts, Congress, and the Liability of Public Officials for Damages, 1980 SUP. CT. REv. 281, 282; see also Harry A. Blackmun, Section 1983 and Federal Prolection of Individual Rights-Will the Stalule Remain Alive or Fade Away?, 60 N.Y.U. L. REV. 1, 21 (1985) ("I am aware of no statistics demonstrating what percentage of $\S 1983$ actions are bound to be meritless.").

93. See Harlow, 457 U.S. at 814.

94. Id. (quoting Butz v. Economou, 438 U.S. 478, 507-08 (1978)).

95. 420 U.S. 308 (1975). 
cial if she "knew" her actions violated a plaintiff's constitutional rights, or if she acted with malicious intent to cause a constitutional deprivation. ${ }^{96}$ The objective component suggested that, even in the absence of subjective knowledge or intent, an official could not claim qualified immunity if she "reasonably should have known" that her actions violated the Constitution. ${ }^{97}$

The Harlow Court concluded that the subjective component of the Wood test had "proved incompatible with our admonition ... that insubstantial claims should not proceed to trial." were incurred, the Court speculated, as a result of judicial inquiries into officials' subjective good faith, a question of fact ordinarily requiring a jury's resolution. ${ }^{99}$ Moreover, additional "special" costs accrued from the litigation of the subjective good faith issue. ${ }^{100}$ The Court noted that because immunity is generally available only to public officials who are engaged in discretionary functions, such officials would be subject to discovery concerning the exercise of their judgment based on their "experiences, values, and emotions." These factors are so inherently variable, the Court argued, that their resolution on summary judgment would be difficult. ${ }^{102}$ Moreover, judicial inquiry into officials' subjective motivation would require extensive discovery, with depositions targeting many of the officials' professional colleagues. ${ }^{103}$ "Inquiries of this kind," the Court observed, "can be peculiarly disruptive of effective government."104

In order to limit these concerns with the costs of constitutional tort litigation, the Harlow Court reformulated the qualified immunity doctrine in two important ways. First, the Court eliminated the subjective prong of the Wood immunity test and instead established an "objective" test, entitling an official to qualified immunity only if, in the performance of discretionary functions, her actions did not violate "clearly established statutory or constitutional rights of which a reasonable person would have known." 105 By shifting to an objective test, the Court reasoned, the qualified immunity standard would facilitate resolution of insubstantial claims on summary judgment, thus

96. See id. at 322.

97. See id.

98. Harlow, 457 U.S. at 815-16.

99. See id. at 816.

100. See id.

101. Id.

102. Seeid.

103. See id. at 817 .

104. Id. (footnote omitted).

105. Id. at 818 . 
avoiding the unnecessary disruption of government. ${ }^{106}$ Bare allegations of the defendant's malice would no longer be sufficient to subject government officials to trial or "the burdens of broad-reaching discovery." 107

Second, in order to ensure the early termination of insubstantial lawsuits, the Court sought to create a procedural mechanism for disposing of constitutional tort cases at the earliest possible stage of litigation. ${ }^{10 x}$ This could be achieved in most cases through summary judgment, the Court insisted, because qualified immunity is an issue of law. ${ }^{109}$ Importantly, it noted that until the threshold immunity question was resolved, no discovery should be permitted. ${ }^{110}$

Under Harlow, the judge should evaluate the defendant's summary judgment motion based on the currently applicable law and whether that law was clearly established at the time of the defendant's allegedly unconstitutional conduct. ${ }^{11}$ Because it is unreasonable to expect public officials to anticipate future legal developments, qualified immunity would apply in situations where the law was not clearly established at the time of the alleged violation. ${ }^{112}$ Where the law was clearly established, however, the immunity defense would ordinarily fail, "because reasonably competent public officials should know the law governing their conduct." 113

The Harlow Court's move from a dual subjective/objective test to a purely objective test and adoption of streamlined summary judgment procedures reflects an important shift in the policy concerns underlying immunity. In Pierson, Scheuer, and Wood, the Court focused on the problems associated with constitutional tort liability, but did not expressly acknowledge the social costs of constitutional tort litigation,

106. See id.

107. Id.

108. See id. at 814 .

109. See id. at 818 . The Court continues to insist that an official's entitlement to qualified immunity is a question of law. See Elder v. Holloway, 510 U.S. 510, 515 (1994).

110. See Harlow, 457 U.S. at 818.

111. See id.

112. See id.

113. Id. at 818-19. An official may still escape liability, even if the relevant law was clearly established, "if the official pleading the defense claims extraordinary circumstances and can prove that he neither knew nor should have known of the relevant legal standard." Id. at 819. The Court emphasized, however, that the defense would still turn primarily on objective factors. See id. In his concurrence, Justice Brennan argued that this part of the majority opinion left open the possibility that some subjective element remained relevant to the qualified immunity inquiry:

This standard would not allow the official who actually knows that he was violating the law to escape liability for his actions, even if he could not "reasonably have been expected" to know what he actually did know. Thus the clever and unusually well informed violator of constitutional rights will not evade just punishment for his crimes. Id. at 821 (Brennan, J., concurring) (internal citations omitted). 
independent of the case's outcome. Harlow's shift to an objective standard manifested, in part, the Court's increasing concern not so much with the unfairness of imposing financial liability on public officials sued in constitutional tort, but with the actual burdens attendant to the litigation process itself.

This is clear because immunity from pretrial processes as envisioned by Harlow is not driven by fairness or overdeterrence concerns. Those interests could be adequately protected by a substantive defense to liability even after discovery and a full trial. The fairness justification for qualified immunity, for example, centers on the unfairness of imposing financial liability on officials for their exercise of discretionary authority. From a substantive standpoint, the Wood test would theoretically account for those concerns, for fairness would seem to be epitomized by a subjective immunity test. A subjective test, after all, requires examination of the defendant's actual knowledge or intent regarding a particular action. If a defendant did not know she was committing a constitutional infraction and did not intend to violate the plaintiff's constitutional rights, a fairness argument can be made that she should not be punished. The addition of an objective component to the test, as the Wood Court recognized, was necessary to prevent officials from deliberately remaining ignorant of the law in order to avoid liability. ${ }^{114}$ But those broader societal concerns have nothing to do with fairness to the official.

The Court itself discussed the distinction between a substantive liability defense and an immunity from pretrial litigation in Anderson $v$. Creighton. ${ }^{115}$ In Anderson, a family filed a Bivens action against an FBI agent, claiming deprivation of their Fourth Amendment rights in relation to a warrantless search of their home. ${ }^{116}$ The agent had been pursuing a bank robbery suspect whom he believed was in the plaintiffs' home. ${ }^{117}$ The agent claimed not only that he had probable cause, but also that exigent circumstances excused the presumptive warrant requirement. ${ }^{118}$ Anderson adhered to Harlow's objective reasonableness standard and held that law enforcement officers are entitled to immunity when they reasonably could have believed their conduct to be lawful. $^{119}$

Justice Stevens dissented, observing that the varying interests protected by the qualified immunity doctrine could not be equally ful-

114. See Wood, 420 U.S. at $321-22$.

115. 483 U.S. 635 (1987).

116. See id. at 637 .

117. See id.

118. See id.

119. See id. at 638. 
filled in all types of cases. ${ }^{120}$ The immunity doctrine's procedural structure for early termination of constitutional tort cases, he argued, was designed to prevent two social harms-the burdens and distractions of civil rights litigation on busy public officials, and the unfairness of holding those officials liable for actions in which no clear constitutional principle is violated. ${ }^{121}$ Harlow immunity may protect both of these interests by freeing defendants from the burdens of pretrial litigation, but only in cases when the qualified immunity defense is used to attack the plaintiff's legal claim or theory in the abstract. ${ }^{122}$ In other cases, however, the defendant's immunity claim may be focused not on the abstract nature of the plaintiff's legal claim, but on the character of the defendant's conduct. ${ }^{123}$

In the latter category of cases, Justice Stevens concluded, public officials might not be able to avoid the burdens of pretrial litigation because " $[t]$ he strength of the reasonable good-faith defense in any specific case would, of course, vary with the trial evidence about the facts upon which the officer had relied when he made the challenged search or arrest." In these types of cases, Justice Stevens observed, public officials still could argue that they should be excused from liability based on the reasonableness of their conduct but could not expect to benefit from a Harlow immunity from the pretrial litigation process. ${ }^{125}$ Fairness concerns could therefore be vindicated even if the case went to trial, assuming appropriate room for mistaken judgments could be taken into account by the fact finder.

The Anderson majority, however, responded that requiring officials even to litigate the case presented problems. ${ }^{126}$ In a candid acknowledgment of Harlow's transformation of the law, the Court observed that Justice Stevens's identification of a good faith immunity to be litigated at trial "would totally abandon the concern-which was the driving force behind Harlow's substantial reformulation of qualified-

120. See id. at 647 (Stevens, J., dissenting). In addition to his criticism of the procedural aspects of immunity, Justice Stevens also dissented on several substantive issues. He argued, for instance, that applying qualified immunity in this context gave law enforcement officers additional, but unnecessary, protection from liability. See id. at 659-65. Justice Stevens also agreed with the plaintiffs that the Fourth Amendment's substantive reasonableness standard adequately protected officials for their reasonable mistakes. See id. at 663-64.

121. See id. at 649. Implicit in his discussion is that the "burdens and distractions" include both the overdeterrence and social cost rationales discussed above.

122. See id. at 650-51.

123. See id.

124. Id. at 653 (footnote omitted).

125. See id. at 652-53. Justice Stevens pointed out that such a defense, which would allow the official to offer evidence about the reasonableness of her conduct at trial, was recognized by the court of appeals on remand in Bivens itself. See id.

126. See id. al 638-39. 
immunity principles - that 'insubstantial claims' against government officials be resolved prior to discovery and on summary judgment if possible."127 The majority also speculated that clever plaintiffs would always be able to identify an "abstract clearly established right," which would necessitate the type of development of facts that would undermine the immunity from the pretrial litigation process. ${ }^{128}$ The majority's analysis further illustrates that social cost, rather than fairness, is the principal concern when the Court creates mechanisms for early termination of constitutional tort claims.

Indeed, other cases reinforce the notion that fairness considerations arise from the Court's concerns about the imposition of financial liability, not from the burdens of litigation. ${ }^{129}$ In Owen $v$. City of Independence, ${ }^{130}$ the Court rejected a municipality's claim that local government entities should be entitled to qualified immunity for their employees' reasonable actions. ${ }^{131}$ The Court observed that "the [fairness] consideration is simply not implicated when the damages award comes not from the official's pocket, but from the public treasury." 132 Yet, in a municipal liability case, the individual officials involved in the challenged conduct would be subject to the same, if not identical, litigation burdens as if they were sued in their individual capacities. Their time and attention would still be taken away from their primary public duties and directed toward responding to the litigation. Thus, the Court does not appear to consider the burdens associated with the litigation itself to implicate substantial fairness concerns.

Only if one conceives of subjecting officials to the burdens of litigation as a source of unfairness, independent of their liability, can early termination of constitutional tort litigation be said to advance fairness concerns. Surely, it is in some sense unfair to subject an official to lengthy litigation even if the official is ultimately vindicated on immunity grounds. Litigation, after all, is an additional burden on that official's life. Moreover, if the official bears the cost of defense, then extensive litigation of the claim could certainly be unfair. Nonetheless, as Justice Stevens has observed, dealing with litigation is

127. Id. at 640 n.2 (citing Harlow v. Fitzgerald, 457 U.S. 800, $818-19$ (1982)).

128. See id.

129. To a significant extent, meaningful assessments of the relationship between exposure to litigation burdens (as opposed to ultimate liability) and both fairness and overdeterrence considerations must be empirically based. Thus, in making this argument, I am vulnerable to the same criticisms I make later in this Article concerning the lack of empirical bases for formulating qualified immunity doctrine. See infra notes 601-05 and accompanying text.

130. 445 U.S. $622(1980)$.

131. See id. at 653-54.

132. Ild. 
part of the official responsibilities of many public officials. ${ }^{133}$ Furthermore, the unfairness associated with bearing the litigation expenses is eliminated if, as in many cases, those costs are borne by the government entity. ${ }^{134}$

Finally, it is possible that the fairness consideration is advanced by eliminating the risk of financial liability that comes with extensive litigation. In other words, it could be that early termination of suits alleviates a psychological burden on officials that would otherwise exist if they could present a substantive reasonableness defense only at trial. Even that concern should be relatively less significant if, as Justice Stevens suggested in his dissent in Anderson, the court and the jury can accommodate room for official error in their liability determination. ${ }^{135}$ The availability of a substantive defense for reasonable mistakes should relieve officials of at least some of the psychological burdens associated with the risk of liability.

The Court's transformation of the immunity doctrine in Harlow also signifies a departure from the overdeterrence rationale. Again, the emphasis on resolving immunity at the earliest possible stage appears primarily to underscore a concern about the costs of pretrial litigation. The importance of early termination of litigation in advancing the overdeterrence consideration depends in great measure on the impact the anticipated burdens of litigation would have on an official's conduct.

It seems less likely that an official would be deterred from acting merely because of the possibility of litigation, than that her conduct would be affected by the possibility of liability. While it is reasonable to assume that most public officials would prefer not to be dragged through court, it is the ultimate financial responsibility that would seem to provide the greatest disincentive to act with candor and dispatch while performing one's official duties. An official may hesitate in deciding a course of action if she is haunted by the potentially significant financial costs, but is at least less likely to second guess her conduct merely because she may be sued unsuccessfully.

The Court's reasoning in other immunity cases is consistent with this analysis. In Owen, for example, the majority observed that fi-

133. See Anderson, 483 U.S. at 662 (Stevens, J., dissenting) (observing that participating in litigation is part of a law enforcement officer's job and does not represent as significant a disruption in official duties as it would for a high level official).

134. See K.H. v. Morgan, 914 F.2d 846, 850 (7th Cir. 1990) (noting that it is increasingly common for government entities to indemnify their employees for damages and other expenses incurred in defending constitutional tort actions).

135. See Anderson, 483 U.S. at 659 (Stevens, J., dissenting). 
nancial liability is the main source of the chilling effect on official behavior.

At the heart of this [overdeterrence] justification for a qualified immunity for the individual official is the concern that the threat of personal monetary liability will introduce an unwarranted and unconscionable consideration into the decisionmaking process, thus paralyzing the governing official's decisiveness and distorting his judgment on matters of public policy. The inhibiting effect is significantly reduced, if not eliminated, however, when the threat of personal liability is removed. ${ }^{136}$

Similarly, in Pulliam v. Allen, ${ }^{137}$ where the Court considered the scope of judicial immunity from claims for injunctive relief and attorneys' fees, the majority argued that judges would not be overdeterred simply by the possibility of having to answer and defend injunctive claims. $^{138}$ The Court again contended that the threat of overdeterrence comes most sharply from the threat of personal financial liability. ${ }^{139}$

Justice Powell, who dissented in both Owen and Pulliam, argued that litigation, rather than liability, was a source of overdeterrence. In Owen, he maintained that officials were as likely to be chilled by potential judgments against the municipality as they would by fear of personal financial loss. ${ }^{140}$ The majority dismissed his concerns, first noting that officials routinely make decisions that may cost their government employer substantial amounts of money. ${ }^{141}$ Moreover, the majority argued that as a normative matter, considerations about municipal liability should constrain public officials' decisions but were less likely to do so than the threat of personal liability. ${ }^{142}$

136. Owen, 445 U.S. at 655-56 (footnote omitted); see also Morgan, 914 F.2d at 850 (stating that overdeterrence justification becomes "strained" when governmental entities indemnify their employees for damages and other expenses incurred in defending constitutional tort actions).

137. 466 U.S. 522 (1984).

138. See id. at 536 ("We never have had a rule of absolute judicial immunity from prospective relief, and there is no evidence that the absence of that immunity has had a chilling effect on judicial independence."). In 1996, Congress enacted the Federal Courts Improvement Act of 1996, in which it overruled Pulliam. See Federal Courts Improvement Act of 1996, Pub. L. No. 104-317, 1996 U.S.C.C.A.N. (110 Stat.) 3847 (codified as amended at 42 U.S.C. $\$ \S 1983$, 1988).

139. See Pulliam, 466 U.S. at 537 ("For the most part, injunctive relief against a judge raises concerns different from those addressed by the protection of judges from damages awards."). The Court recognized that judicial exposure to attorneys' fees awards raised more logical concerns about the chilling effect, but concluded that Congress's intent to impose fee liability on judges overrode that concern. See $i d$. at 543 . Congress has since changed its judgment on the matter. See supra note 138 and accompanying text.

140. See Owen, 445 U.S. at 668-69 (Powell, J., dissenting).

141. See id. at 656 .

142. See id. 
In Pulliam, Justice Powell contended that the actual burden of litigation, rather than the possibility of pecuniary loss, threatens judicial independence and decisionmaking. ${ }^{143}$ The majority in Pulliam, in contrast, maintained that there was no evidence that injunctive suits against judges, which were available under common law, had affected judicial independence in any way. ${ }^{144}$ Moreover, it is noteworthy that common procedures such as appeals and stays are often the functional equivalent of injunctive actions against judges, yet there appears to be little concern about overdeterrence in those contexts.

Thus, the Court's focus on fairness and overdeterrence justifications seems to have diminished since its decision in Harlow. Moreover, the Court's post-Harlow immunity decisions have continued to emphasize the early and prompt determination of immunity questions to minimize social costs. In Mitchell v. Forsyth, ${ }^{145}$ for example, the Court held that where a lower court denied a public official's qualified immunity claim, the official was entitled to an interlocutory appeal prior to the onset of potentially burdensome discovery or trial. ${ }^{146}$ The Mitchell Court reasoned that much of the value of immunity would be lost if an immunity claim were wrongly denied, thus forcing the defendant to litigate the claim through discovery and trial before vindicating her immunity argument. ${ }^{147}$ The Court emphasized that qualified immunity is "an immunity from suit rather than a mere defense to liability." ${ }^{48}$ In this respect, then, qualified immunity shares an "essential attribute of absolute immunity-... an entitlement not to stand trial under certain circumstances."

The Supreme Court's express and primary goal of early termination of civil rights claims relies on two principal premises. The first premise is that qualified immunity is a question of law. The second premise is that summary judgment is an appropriate and effective procedural vehicle for resolving qualified immunity claims. In the following sections, this Article explores and critiques each of these premises.

143. See Pulliam, 466 U.S. at 554 (Powell, J., dissenting).

144. See id. at 536. It should be acknowledged that the Court's analysis in Owen and Pulliam is not entirely analogous to circumstances where officials could advance a substantive defense to liability without the benefit of early termination, as discussed in Justice Stevens's Anderson dissent. See Anderson v. Creighton, 483 U.S. 635, 652-53 (1987) (Stevens, J., dissenting). In Owen and Pulliam, the officials had no risk of financial liability, whereas some risk still exists when an official can assert a substantive defense to liability, but has no protection from pretrial litigation burdens.

145. 472 U.S. 511 (1985).

146. See id. at 525-27.

147. See id. at 526 .

148. Id.

149. Id. at 525. 


\section{THE ROLE OF FACTS IN QUALIFIED IMMUNITY ANALYSIS}

In order for qualified immunity to achieve its primary goal of limiting social costs, it must be structured in a manner that will facilitate early termination of constitutional tort claims when the defendant has not violated a "clearly established" constitutional right. Consistent with this objective, the Court has repeatedly emphasized that qualified immunity is a question of law. ${ }^{150}$ This Part explores why, despite the Court's stated objectives, the promise of early resolution of qualified immunity claims has become illusory. Under current doctrine, it should be virtually impossible to adjudicate qualified immunity claims before resolution of important facts by the fact finder. ${ }^{151}$

\section{A. The Basic Factual Dispute}

One scenario in which the courts have agreed that qualified immunity cannot be satisfactorily resolved in a pretrial setting is when there exists a genuine factual dispute concerning a foundational element of a plaintiff's claim. This is sometimes labeled the "I didn't do it" defense. ${ }^{152}$

Suppose, for example, that a plaintiff files a $\S 1983$ claim alleging that a law enforcement officer conducted a warrantless search of her home in violation of the Fourth Amendment. The defendant files a summary judgment motion, supporting it with an affidavit denying that she ever entered the plaintiff's home, much less in an unreasonable manner. The defendant officer also argues that nothing in the record establishes her presence at the scene of the alleged violation. With her categorical denial, the officer has fulfilled her initial summary judgment burden both by producing evidence that negates the plaintiff's claim and by highlighting the absence of evidence to support an essential element of the plaintiff's case, thus shifting the burden of production to the plaintiff. ${ }^{153}$

150. See, e.g., Elder v. Holloway, 510 U.S. 510,516 (1994); Mitchell, 472 U.S. at 526; Harlow v. Fitzgerald, 457 U.S. 800,818 (1982).

151. This is not to say that substantial numbers of constitutional tort claims are not being thrown out of court on qualified immunity grounds. But if that is true, the courts may not necessarily be applying the doctrine correctly. It may be that, given the doctrinal difficulties described in this Article, the courts have found other ways to dispose of constitutional tort claims that have converted qualified immunity into more of a pleading rule. Alternatively, the doctrinal complexities may be confusing the courts, which may be disposing of these cases under circumstances in which the qualified immunity defense should be rejected, at least at the pretrial stage. Only empirical research will help answer these questions. See infra Part V.

152. See, e.g., Elliott v. Thomas, 937 F.2d 338, 342 (7th Cir. 1991).

153. See Celotex Corp. v. Catrett, 477 U.S 317, 325 (1986) (holding that initial burden on moving party is "discharged when party shows a lack of evidence in favor of nonmoving party's claim); see also infra notes 378-86 and accompanying text (discussing the "highlighting" burden on the moving party as established in Celotex). 
Plaintiff then files her response, which includes: (1) an affidavit swearing that she saw the officer enter her home and go through her personal belongings; and (2) a photograph of an unidentified police officer leaving her ransacked home. The plaintiff has now met her summary judgment production burden by presenting evidence that, taken in the light most favorable to her, could convince a reasonable jury that she should prevail by a preponderance of the evidence. ${ }^{154}$ Even under the heightened summary judgment standards recently imposed by the Court, ${ }^{155}$ the plaintiff can meet her summary judgment burden because she has more than a "scintilla of evidence" to support her claim. ${ }^{156}$ Under existing law, it generally would be agreed that the claim must go to trial.

The same outcome must occur in a myriad of constitutional tort claims where the defendant denies some essential element of the plaintiff's claim. ${ }^{157}$ Sometimes the disputed historical event will be a specific act, such as a physical blow, ${ }^{158}$ the entry into a dwelling, ${ }^{159}$ the deprivation of or damage to property, ${ }^{160}$ or the extent of procedures provided to a public employee before job termination. ${ }^{161}$ Disputes may also arise regarding whether the plaintiff has even identified and sued the correct defendants, those responsible for the unconstitutional conduct that resulted in harm. ${ }^{162}$

In other contexts, the dispute might center on the defendant's knowledge or awareness of a specific fact. For example, in an Eighth Amendment case involving a prisoner's claim that officials failed to provide adequate security, a factual issue concerning whether the of-

154. See Anderson v. Liberty Lobby, Inc., 477 U.S. 242, 252 (1986) (holding that judge must ascertain whether a fair-minded jury could return a verdict for the plaintiff on the evidence presented); see also infra notes $391-408$ and accompanying text.

155. See infra Part III.

156. See Liberly Lobby, 477 U.S. at 252.

157. One other commentator has noted the substantial number of cases in which qualified immunity claims are denied based on a disputed material fact. See Kinports, Unanswered Queslions, supra note 28 , at $647 \mathrm{n} .203$.

158. See, e.g., Elliott v. Thomas, 937 F.2d 338, 343 (7th Cir. 1991) (holding that police officers were not entitled to dismissal of excessive force claim on qualified immunity grounds because of factual dispute).

159. See, e.g., Marks v. Clarke, 102 F.3d 1012, 1025 (9th Cir. 1996) (rejecting qualified immunity where genuine issue of fact exists regarding whether defendants forcibly entered residence to conduct search), cert. denied, 118 S. C.t. 264 (1997).

160. See, e.g., Liston v. County of Riverside, 120 F.3d 965, 979 (9th Cir. 1997) (noting genuine issue of fact regarding when property damage occurred).

161. See, e.g., Langley v. Adams County, 987 F.2d 1473, 1480-81 (10th Cir. 1993) (upholding district court's denial of qualified immunity to defendant when issues of material fact exist regarding whether plaintiff received due process).

162. See, e.g., Burns v. County of Cambria, 971 F.2d 1015, 1018 (3d Cir. 1992) (rejecting qualified immunity claim based on defendants' contention that they were not responsible for firing plaintiffs, rather than on claim that if they did fire the plaintiffs it was not in violation of clearly established rights). 
ficials knew of the substantial risk to the inmate might be present. ${ }^{163}$ Similarly, in an Eighth Amendment claim based on prison officials' provision of inadequate medical care, there may exist an issue concerning whether a particular official knew about the plaintiff's condition or medical needs. ${ }^{164}$ In Fourth Amendment cases, there may be substantial factual disputes concerning what facts an official knew at the time she decided to seize or search a plaintiff, ${ }^{165}$ or the amount of force used. ${ }^{166}$ Likewise, in a case involving First Amendment employee speech, a factual issue may arise concerning whether a public employer had knowledge of a plaintiff's statements and considered them in taking some detrimental employment action against the plaintiff. ${ }^{167}$ Similarly, the employer's motive for taking action against the employee may be in dispute. ${ }^{168}$ In a range of other types of constitutional tort cases, discussed below, the factual dispute also may center on the defendant's state of mind. ${ }^{169}$

Sometimes the factual dispute will focus on whether something has occurred that would constitute an excuse for, or exception to, the relevant constitutional rule. For example, in a Fourth Amendment illegal search context, the defendant could claim that facts existed that constituted "exigent circumstances" under the law. ${ }^{170}$ In claims that police interrogation tactics have violated the Fifth or Fourteenth Amendment Due Process Clauses or the right to counsel derived from the Fifth and Sixth Amendments, the defendant may dispute

163. See Farmer v. Brennan, 511 U.S. 825, 837 (1994) (holding that prison official may not be liable under Eighth Amendment unless official has knowledge of risk to inmate's safety and disregards such risk).

164. See Kaminsky v. Rosenblum, 929 F.2d 922, 927 (2d Cir. 1991) (describing factual dispute concerning defendants' knowledge of plaintiff's medical condition).

165. See, e.g., Act Up!/Portland v. Bagley, 988 F.2d 868, 873 (9th Cir. 1993) (remanding issue of qualified immunity for a determination of whether material facts were in dispute).

166. Rainey v. Conerly, 973 F.2d 321, 324 (4th Cir. 1992) (rejecting qualified immunity claim in excessive force case because of factual disputes).

167. See, e.g., Churchill v. Waters, 977 F.2d 1114, 1128-29 (7th Cir. 1992) (holding that employer should have known speech was protected by First Amendment, and rejecting qualified immunity claim because of material fact issues regarding content of plaintiff's speech), vacated, 511 U.S. 661 (1994).

168. See, e.g., Langley v. Adams County, 987 F.2d 1473, 1479 (10th Cir. 1993) (finding material fact concerning defendant's reason for discharge to be in dispute where defendant claims plaintiff was discharged for "insubordination" and plaintiff questions defendant's motive); Gorman v. Robinson, 977 F.2d 350, 355 (7th Cir. 1992) (noting genuine fact issue regarding employer's motive for firing employee).

169. See infra notes $312-22$ and accompanying text.

170. See, e.g., Crawford-El v. Britton, 93 F.3d 813, 820 (D.C. Cir. 1996) (en banc) (noting that unreasonable search or seizure claims "will often turn on whether the defendant was in possession of facts that would have led a reasonable officer to suppose he had probable cause or exigent circumstances"), cert. granted, 117 S. Ct. 2451 (1997); see also Anderson v. Creighton, 483 U.S. 635, 641 (1987) (noting that qualified immunity claim regarding exigent circumstances is "fact-specific" and may involve issue of officer's knowledge of specific information). 
the factual circumstances of the questioning ${ }^{171}$ or assert facts that suggest that the plaintiff was not prejudiced by official questioning outside the presence of counsel..$^{172}$

The factual denial defense carries with it not only the practical problem that pretrial termination is unlikely, if not impossible, but also the more fundamental conceptual problem of categorizing this type of defense. For in the cases described, courts should recognize that the qualified immunity defense really has no meaning. Whenever the defense is predicated on the denial of some crucial element of the plaintiff's case, the issue may better be framed as a defense on the merits. ${ }^{173}$

The Seventh Circuit acknowledged this point in Elliott $v$. Thomas. ${ }^{174}$ In Elliott, the plaintiff alleged that defendants used excessive force during an arrest, puncturing plaintiff's eardrum in the process. ${ }^{775}$ The officers denied that they had caused any physical injury to the plaintiff. ${ }^{176}$ As Judge Easterbrook correctly observed,

[ $t$ ] his legal debate [over the clarity of the constitutional right at stake] has nothing to do with their defense-that they did not injure Elliott at all. If they punctured Elliott's eardrum without provocation, as Elliott contends, then Elliott recovers under any standard; if the defendants did nothing, as they say, then they prevail under any standard. ${ }^{177}$

171. See, e.g., Giuffre v. Bissell, 31 F.3d 1241, 1258 (3d Cir. 1994) (rejecting qualified immunity defense to substantive due process claim based on factual dispute about intimidation during interrogation).

172. See Cinelli v. City of Revere, 820 F.2d 474, 477 (1st Cir. 1987) (concluding that qualified immunity defense must be rejected on Sixth Amendment claim when genuine fact issue exists regarding whether plaintiff suffered prejudice). There is substantial controversy over whether constitutional tort actions for such claims are cognizable when they are based on the Fifth Amendment. Compare Cooper v. Dupnik, 963 F.2d 1220, 1237 (9th Cir. 1992) (en banc) (recognizing plaintiff's $\$ 1983$ action for violation of Fifth Amendment counsel rights during custodial interrogation for failure to provide Miranda warnings), with Giuffre, 31 F.3d at 1246 (characterizing dissenting judges' position in Cooper that Fifth Amendment right is not violated until evidence is admitted to be "persuasive"). For a broad discussion of this issue, see Martin R. Gardner, Section 1983 Actions Under Miranda: A Critical View of the Right to Avoid Interrogation, $30 \mathrm{AM}$. CRIM. L. REV. 1277 (1993) (arguing that no $\$ 1983$ action ought to be available to enforce Miranda rights, but that such rights should be enforced through the exclusionary rule); Susan R. Klein, Miranda Deconstitutionalized: When the Self-Incrimination Clause and the Civil Rights Act Collide, 143 U. PA. L. REV. 417, 434-48 (1994) (describing how the courts' narrow interpretations of Miranda, coupled with doctrinal developments under $\$ 1983$, have severely limited the enforcement of Miranda rights).

173. See Blum, User's Manual, supra note 14, at 214 (noting that the "I didn't do it" defense clearly goes to the merits of the case).

174. 937 F.2d 338, 342 (7th Cir. 1991).

175. See id. at 340 .

176. See id. at 343 .

177. Id; cf. Johnson v. Jones, 515 U.S. 304, 316-17 (1995) (rejecting interlocutory appellate jurisdiction on qualified immunity claim when central dispute was factual issue of whether defendants even touched plaintiff). Of course, an official could plead alternative defenses, claiming that she didn't do anything, but that even assuming she did, she is immune. 
In Burms v. County of Cambria, ${ }^{178}$ the Third Circuit addressed a comparable argument. The plaintiffs in Bums were deputy sheriffs and other officials who claimed they had been fired for failing to support the sheriff in an election, or because they had supported his opponent, or for both reasons. ${ }^{179}$ One group of defendants asserted qualified immunity, denying that they were responsible for firing the plaintiffs. ${ }^{180}$ The .court rejected their defense and observed that their claims

were that they were not responsible for firing the plaintiffs. They did not claim that even if they had fired the plaintiffs, that action would not have violated the plaintiffs' clearly established constitutional rights. Only the latter contention would have invoked the qualified immunity defense. The former statement is simply the "I didn't do it" defense and therefore not cognizable as an assertion of qualified immunity. ${ }^{181}$

It was the complications associated with evaluating factual questions in these types of cases that led the Supreme Court in Johnson $v$. Jones to narrow the scope of interlocutory appeals from the denial of qualified immunity. ${ }^{182}$ In Johnson, the Court concluded that if the trial court bases its rejection of a qualified immunity claim on the presence of genuine issues of fact concerning a principal element of the plaintiff's case, the defendant may not pursue an interlocutory appeal on immunity. ${ }^{183}$ Such appeals are ordinarily permissible under the Court's holding in Mitchell v. Forsyth. ${ }^{184}$ The Johnson Court held, however, that in the context of the "I didn't do it" defense, the claims do not fit within the exceptions to the final order rule because they do not resolve an important issue completely separate from the merits of the action. ${ }^{185}$ In such cases, the Court concluded, no separate question exists that is "significantly different from the factrelated legal issues that likely underlie the plaintiff's claim on the merits." ${ }^{\text {"866 }}$ Thus, claims that involve central factual disputes are in-

178. 971 F.2d 1015 (3d Cir. 1992).

179. See id. at 1017-18.

180. See id. at 1019.

181. Id. (emphasis added).

182. See Johnson, 515 U.S. at 316.

183. See id.

184. 472 U.S. 511 (1985) (holding that district court's order denying public official's motion for summary judgment is immediately appealable if issue is a matter of law).

185. See Johnson, 515 U.S. at 316-17.

186. See id. at 314. Prior to Johnson, many federal appellate courts had made it clear that summary judgment would be an inappropriate mechanism to resolve such disputes, and similarly denied interlocutory appellate jurisdiction to officials whose qualified immunity claims were denied by the trial court on summary judgment. See Elliott v. Thomas, 937 F.2d 338, 34041 (7th Cir. 1991); Kaminsky v. Rosenblum, 929 F.2d 922, 926 (2d Cir. 1991); Boulos v. Wilson, 834 F.2d 504, 509 (5th Cir. 1987). 
separable from claims on the merits, and pretrial adjudication of such disputes must follow the course of ordinary summary judgment motions.

\section{B. The Inherently Fact-Based Nature of the Qualified Immunity "Reasonableness" Standard}

Summary judgment might still be an effective device for screening out weaker cases and facilitating the goal of minimizing the social costs of civil rights litigation if the legal doctrine were structured to limit irresolvable qualified immunity claims to those with factual disputes concerning the basic elements of the plaintiff's case. A more general argument about the factual nature of qualified immunity may be derived, however, from the Court's articulation of the qualified immunity standard itself.

In cases prior to its recent fixation on the early termination of constitutional tort claims, the Court recognized that factual inquiry would be an important aspect of qualified immunity. Tracing the development of the qualified immunity standard reveals the inherently factual nature of the "clearly established rights" or "reasonableness" inquiry.

As described above, the Court in Harlow $v$. Fitzgerald ${ }^{187}$ transformed the qualified immunity doctrine in two important ways in order to facilitate prompt pretrial adjudication. First, the Court eliminated the subjective prong of the immunity analysis in order to inhibit plaintiffs from conducting extensive discovery that would interfere with the effective administration of government. ${ }^{188}$ Second, the Court proposed summary resolution under Rule 56 , stating that entitlement to qualified immunity is a question of law. ${ }^{189}$ In decisions since Harlow, while the Court has hedged on its formal adherence to these doctrinal principles, it has not specifically recanted them either. This uncertainty has led to a great deal of confusion among lower courts and academic commentators.

The central difficulty with Harlow's approach is that it obscures the inherent role that facts play in all qualified immunity claims, not simply those involving an inquiry into subjective good faith. Long before Harlow, the Court recognized that development of facts would often be necessary in order to evaluate the defendant's assertion of qualified immunity. These decisions reflected the Court's understanding that the immunity inquiry must be related not only to the 
official's objective reasonableness, but also to the assessment of that belief in relation to the particular facts before her. In Scheuer $v$. Rhodes, for example, the Court noted that "[i]f the immunity is qualified, not absolute, the scope of that immunity will necessarily be related to facts as yet not established either by affidavits, admissions, or a trial record." 190

Similarly, in O'Connor $v$. Donaldson, ${ }^{191}$ the Court examined a qualified immunity claim asserted by a state mental hospital administrator who was sued for unconstitutionally depriving the plaintiff of his physical liberty when he authorized the plaintiff's civil commitment and continued institutionalization for fifteen years. ${ }^{192}$ Although the trial court had instructed the jury that the defendant could not be held liable if he had a reasonable and good faith belief that his actions were proper, the Court remanded the case for consideration in light of Wood, which had not yet been decided at the time of the trial. ${ }^{193}$ In doing so, the Court unequivocally stated that the question the jury must answer is whether the defendant knew or reasonably should have known that his actions violated the plaintiff's constitutional rights. ${ }^{194}$ At least one contemporary pre-Harlow commentator understood qualified immunity to have a necessary factual component as well. ${ }^{195}$

These early references to factual issues could be attributed, in part, to the necessity of examining the officials' intentions under the subjective prong of the Wood test. Indeed, it was this precise concern that led the Harlow Court to abandon the subjective component of the analysis, arguing that "substantial costs attend the litigation of the subjective good faith of government officials." 196

190. Scheuer v. Rhodes, 416 U.S. 232, $242-43$ (1974) (emphasis added). Indeed, the Court remanded the cases after concluding that "in their present posture, [these cases] present no occasion for a definitive exploration of the scope of immunity available to state executive officials nor, because of the absence of a factual record, do they permit a determination as to the applicability of the foregoing principles to the respondents here." Id. at 249.

191. 422 U.S. 563 (1974).

192. See id. at 564-65.

193. See id. at 576-77. The Court also remanded because the trial court had refused the defendant's proposed jury instruction stating that he could be excused if he acted in reliance on existing state law, and it directed the lower court to consider whether that omission rendered the other jury instructions invalid. See id.

194. See id. at 577 (citing Wood v. Strickland, 420 U.S. 308, 322 (1995)).

195. See Kathryn Dix Sowle, Qualified Immunity in Section 1983 Cases: The Unresolved Issues of the Conditions For Its Use and the Burden of Persuasion, 55 Tul. L. Rkv. 326, 340 (1981) (arguing that the Court erred in Procunier v. Navarette, 434 U.S. 555 (1978), by applying qualified immunity to the defendants "despite the absence in the record of the factual predicate for its use required by previous immunity decisions") (footnote omitted).

196. Harlow v. Fitzgerald, 457 U.S. 800, 816 (1982). The Court argued that the experience of the lower courts applying the Wood test supported this concern. It noted that "an official's subjective good faith has been considered to be a question of fact that some courts have re- 
But eradication of the subjective good faith component of the qualified immunity analysis should not have changed the Court's view of the need for factual records. In Scheuer, the Court explicitly acknowledged the need for factual development to resolve the objective component of the claim as well. ${ }^{197}$ The Court made clear that

in varying scope, a qualified immunity is available to officers of the executive branch of government, the variation being dependent upon the scope of discretion and responsibilities of the office and all the circumstances as they reasonably appeared at the time of the action on which liability is sought to be based. It is the existence of reasonable grounds for the belief formed at the time and in light of all the circumstances, coupled with good-faith belief, that affords a basis for qualified immunity of executive officers .... ${ }^{198}$

The reference to "reasonable grounds" formed "in light of all the circumstances" unequivocally recognizes the need for development of a record to evaluate the objective component of the qualified immunity test. ${ }^{199}$ Indeed, after holding that state executive officials are entitled to qualified immunity, the Court remanded the case for further proceedings, "either by way of summary judgment or by trial on the merits." 200

Justice Stevens has, on several occasions, pointed out the need for factual development of qualified immunity issues. In Procunier $v$. Navarette, ${ }^{201}$ for example, the plaintiff claimed that prison officials had violated his First Amendment and due process rights by intentionally or negligently interfering with his ability to send mail to legal assistance groups, law students, news media, inmates in other prisons, and friends. ${ }^{202}$ The Supreme Court upheld a lower court's decision granting summary judgment to the defendants based on qualified immunity. ${ }^{203}$ In his dissent, Justice Stevens observed that the majority's decision overlooked the critical importance of the factual basis for the

garded as inherently requiring resolution by a jury." Id. (footnote omitted).

197. See Scheuer v. Rhodes, 416 U.S. 232, 249-50 (1974).

198. Id. at $247-48$ (emphasis added). The contrast was acknowledged by the Court in one of its absolute immunity opinions as well. In Imbler v. Pachlman, 424 U.S. 409 (1976), the Court observed that

[t]he procedural difference between the absolute and the qualified immunities is important. An absolute immunity defeats a suit at the outset, so long as the official's actions were within the scope of the immunity. The fate of an official with qualified immunity depends upon the circumstances and motivations of his actions, as established by the evidence at trial.

Id. at 419 n.13 (citations omitted).

199. See Imbler, 424 U.S. at 419 n.13.

200. Scheuer, 416 U.S. at 250.

201. 434 U.S. 555 (1978).

202. See id. at 557 .

203. See id. at 566 . 
immunity defense. ${ }^{204} \mathrm{He}$ pointed out that contradictory affidavits supported both the plaintiff's and defendants' versions of the facts, and that as the nonmoving party, the plaintiff was entitled to have the courts accept his version of the facts on summary judgment. ${ }^{205}$ The majority, he argued, should not have resolved the immunity claim as a matter of law when the plaintiff had never had an opportunity to develop a factual record, since these questions "could be better answered after, rather than before, trial." 206

While the Court has continued to declare that qualified immunity is a question of law, language from its post-Harlow decisions betrays its ambivalence about this proposition. In Mitchell v. Forsyth, ${ }^{207}$ for example, the Court described qualified immunity as an "essentially legal question" in defining the scope of permissible interlocutory appeals. ${ }^{208}$ Likewise, in Hunter $v$. Bryant, ${ }^{209}$ the Court criticized a lower federal court for reserving resolution of the basis of defendants' qualified immunity claims for a jury. ${ }^{210}$ In so doing, the Court firmly asserted that qualified immunity should ordinarily be decided by a court and should not routinely be placed in a jury's hands. ${ }^{211}$ Even more recently, in Behrens $v$. Pelletier, ${ }^{212}$ the Court reasoned that more than one pretrial appeal may be necessary because the legally relevant factors bearing on the immunity issue may change throughout the pretrial proceedings as the factual record is developed further. ${ }^{213}$ These equivocal characterizations of the immunity issue reflect at least some recognition that a factual component is necessary when evaluating an immunity claim.

The Court's approach to the scope of available discovery on immunity claims provides further evidence of its reluctant acceptance that facts play an important role in qualified immunity analysis. In Harlow, the Court admonished lower courts to examine at the summary judgment stage the question of whether the relevant federal law

204. See id. at 569 (Stevens, J., dissenting).

205. See id.

206. Id. at 574 .

207. 472 U.S. 511 (1985).

208. See id. at 526. Nonetheless, the Court later had to acknowledge that at least some immunity inquiries are factually oriented. See Johnson v. Jones, 515 U.S. 304, 316-17 (1995) (holding that defendants may not file interlocutory appeals when trial court's sole basis for denying their immunity claim is existence of a disputed issue of material fact).

209. 502 U.S. 224 (1991).

210. See id. at 228.

211. See id. For an insightful examination of the necessity for factual inquiries under qualified immunity even after Hunter, see Act Up!/Portland v. Bagley, 988 F.2d 868, 874-83 (9th Cir. 1993) (Norris, J., dissenting from the denial of rehearing en banc).

212. 516 U.S. 299 (1996).

213. See id. at 309 . 
was clearly established. ${ }^{214}$ It emphatically stated that "[u]ntil this threshold immunity question is resolved, discovery should not be allowed." ${ }^{215}$ Later, in Anderson v. Creighton, ${ }^{216}$ the Court was compelled to acknowledge that such limitations on discovery could not always be imposed, even under the objective Harlow standard. ${ }^{217}$ In Anderson, the plaintiffs alleged that law enforcement agents violated their Fourth Amendment rights by entering their home without a warrant or other sufficient legal justification. ${ }^{218}$ Although the parties offered substantially differing accounts both of what happened during the search and of the information on which the agents based their decision to perform the search, the Court extended qualified immunity to the agents. ${ }^{219}$ In articulating the relevant legal standard, the Anderson Court stated that qualified immunity requires an inquiry into the "objective (albeit fact-specific) question whether a reasonable officer could have believed Anderson's warrantless search to be lawful, in light of clearly established law and the information the searching officers possessed." 220 Although this would not entail an inquiry into the official's subjective motivation, it might necessarily require a court to examine the relevant information possessed by the searching officials. $^{221}$

While recognizing the defendants' potential entitlement to qualified immunity, the Court remanded the case for proceedings consistent with its opinion. ${ }^{222}$ In a footnote, the Court provided some guidance to the lower courts in parsing out the factual component of qualified immunity. ${ }^{223}$ The plaintiffs argued that they were entitled to discovery before a proper examination of the immunity question could be conducted. The Court noted, however, that such a rule would undermine the policies driving Harlow's reformulation of immunity law. ${ }^{224}$ Accordingly, the Court offered the following solution:

[O]n remand, it should first be determined whether the actions the Creightons allege Anderson to have taken are actions that a reasonable officer could have believed lawful. If they are, then Anderson is entitled to dismissal prior to discovery. If they are not, and if

214. See Harlow v. Fitzgerald, 457 U.S. 800, 818 (1982).

215. Id.

216. 483 U.S. 635 (1987).

217. See id. at 635-36.

218. See id at 637.

219. See id. at 640,646 .

220. Id. at 641 .

221. See id.

222. Ser id. at 646 n.6.

223. Seeid.

224. See id. 
the actions Anderson claims he took are different from those the Creightons allege (and are actions that a reasonable officer could have believed lawful), then discovery may be necessary before Anderson's motion for summary judgment on qualified immunity grounds can be resolved. Of course, any such discovery should be tailored specifically to the question of Anderson's qualified immunity. ${ }^{225}$

Thus, the Court acknowledged that a factual analysis might preclude early termination, or at least pre-discovery termination, of constitutional tort claims.

More than ten years have passed since Anderson. While courts ${ }^{226}$ and observers ${ }^{227}$ alike have acknowledged that facts may on occasion play a role in qualified immunity decisions, they have not comprehended the breadth of this problem, largely limiting their discussions to the "I didn't do it" situation described above. ${ }^{228}$ Their analysis is dependent upon characterizing qualified immunity as a two-part inquiry. ${ }^{229}$ First, the qualified immunity test is said to inquire whether the law concerning the alleged violation was "clearly established" at

225. Id. (emphasis added) (internal citation omitted).

226. See supra notes 152-86 and accompanying text (outlining the degree to which factual inquiries affect decisions concerning qualified immunity and summary judgment proceedings).

227. See Martin A. Schwartz \& John E. Kirklin, Section 1983 Litigation: Claims, DEFENSES, AND FEES $\$ 9.25$, at 569 (2d ed. 1991) (describing factual component of qualified immunity analysis); Henk J. Brands, Note, Qualified Immunity and the Allocation of Decision-Making Functions Between Judge and Jury, 90 COLUM. L. REv. 1045, 1051-56 (1990) (noting procedural problems that arise when qualified immunity determination is partially fact-based); Cristine Kuhn, Note, Between Scylla and Chanybdis: Can The Supreme Court Rescue the Inimical Qualified Immunily Doclrine?, 43 DRAKE L. REV. 681, 687 (1995) (recognizing that Anderson made the qualified immunity more factually oriented).

228. See generally SCHWARTZ \& KIRKLIN, supra note $227, \$ 9.25$ (focusing on factual conflicts associated with officials' denial that they engaged in conduct underlying plaintiff's suit).

229. It could be argued that the Court's decision in Siegert v. Gilley, 500 U.S. 226 (1991), establishes an even earlier analytical step that requires inquiry into whether the plaintiff has asserted the violation of an existing constitutional right. Siegerl was originally before the Court to review the propriety of a heightened pleading standard in cases asserting intent-based constitutional torts. See infra notes 494512 and accompanying text (noting lower court treatment of heightened pleading standards). Rather than resolving that issue, however, the Court held that the plaintiff's claim failed "at an analytically earlier stage of the inquiry into qualified immunity" because he failed to allege the violation of any constitutional right, much less a clearly established one. See Siegert, 500 U.S. at 233. Applying its holding in Paul v. Davis, 424 U.S. 693 (1976), the Court concluded that because Siegert had alleged nothing more than a reputational injury, there was no constitutionally protected liberty interest at stake. See Siegert, 500 U.S. at 233-34. Scholarly commentary seems to agree that Siegert altered the order in which immunity analysis is to be conducted. See Blum, User's Manual, supra note 14, at 190 (stating that Siegert created "a new structure of analysis" for qualified immunity questions); Patrick E. Higginbotham, Notes on Teague, 66 S. CAL. L. REv. 2433, 2448 (1993) (citing Siegert to illustrate that no advisory opinion problems exist that would prevent courts from addressing the merits of a constitutional claim in a case in which immunity precludes a remedy). This author has argued that this view of Siegert is not conceptually sound. See Chen, supra note 14, at 279 \& n.107. 
the time of the defendant's conduct. ${ }^{230}$ Conventional wisdom suggests that the first part of the qualified immunity inquiry is a pure legal question, suitable for resolution by the courts. ${ }^{231}$ The second part of the inquiry is characterized as whether a reasonable official could have believed that her particular actions violated a clearly established right. ${ }^{232}$ Although some dispute exists, many courts and commentators have viewed this last issue as at least embodying some factual component. $^{239}$ It is only under this last question that the problems arising from the "I didn't do it" defense occur. ${ }^{234}$ The courts appear to have dissected the immunity inquiry into these two distinct issues in order to accommodate the Supreme Court's continuing insistence that qualified immunity is a purely legal question. ${ }^{235}$ This formalistic dichotomy permits courts to argue that the dilemma that arises from factual disputes is an uncommon one.

But this cannot be the case. The nature of the first inquirywhether a constitutional right is "clearly established" at any given point-cannot be understood to be a purely legal question, at least not in most cases. In actuality, the concept of a clearly established right cannot be sufficiently distinguished from the question of whether a reasonable official would have known that a particular act violated that right. ${ }^{236}$ These parts of the qualified immunity inquiry cannot be separated because, whether articulated broadly or narrowly, rights may be understood only in context. ${ }^{237}$

230. See, e.g., Carlo v. City of Chino, 105 F.3d 493, 500 (9th Cir. 1997) (citing Alexander v. County of Los Angeles, 64 F.3d 1315, 1319 (9th Cir. 1995)).

231. See, e.g., Sinaloa Lake Owners Ass'n v. City of Simi Valley, 70 F.3d 1095, 1099 (9th Cir. 1995) (citing Act Up!/Portland v. Bagley, 988 F.2d 868, 871 (9th Cir. 1993)).

232. See, e.g., Carlo, 105 F.3d at 493 (citing Gasho v. United States, 39 F.3d 1420, 1438 (9th Cir. 1994)); Sinaloa, 70 F.3d at 1099 (citing Act Up!/Porlland, 988 F.2d at 871).

233. See Sinaloa, 70 F.3d at 1099 (noting that second prong of test is mixed question of law and fact).

234. See SCHWARTZ \& KIRKLIN, supra note 227, § 9.25, at 518-19 (noting that factual disputes may arise in cases where defendant denies participation in any wrongful act).

235. See, e.g., Hunter v. Bryant, 502 U.S. 224, 227-28 (1991) (emphasizing that questions of immunity should be in the hand of a judge); Mitchell v. Forsyth, 472 U.S. 511, 527-29 (1985) (emphasizing that court should decide immunity questions long before trial). In the early stages of the qualified immunity doctrine's development, even the issue of whether the law was clearly established was treated as a factual, or quasi-factual issue. As one commentator points out, at least one court's assessment of the clearly established rights standard in that period was guided by the expert testimony of a law professor concerning the question of what the law was at the time of the defendant's conduct. See Joseph Kattan, Knocking on Wood: Some Thoughts on the Immunities of Stale Officials to Civil Rights Damages Actions, 30 VAND. L. REV. 941, 986 (1977) (citing Laverne v. Corning, 376 F. Supp. 836 (S.D.N.Y. 1974), affd, 522 F.2d 1144 (2d Cir. 1975)). The Laverne court then submitted the issues concerning the objective prong of the immunity test to the jury. See Laverne, 376 F. Supp. at 836.

236. See Sinaloa, 70 F.3d at 1099 (emphasizing that jury should decide issues of reasonableness of clearly established right).

237. See id. (noting that issues cannot be separated because historical facts relating to official's conduct can only be understood in their specific context rather than abstractly). 
Justice Scalia's opinion for the Court in Anderson explicitly recognized the intertwined nature of these two inquiries. In defining what constitutes a clearly established right, Justice Scalia observed that the qualified immunity standard "depends substantially upon the level of generality at which the relevant 'legal rule' is to be identified." 238 If the appropriate constitutional provision is stated at a broad level of abstraction, such as the right to due process or to free speech, then the rule must always be understood to be clearly established. ${ }^{239}$ If that were the case, however, qualified immunity would never be justified because all public officials can reasonably be expected to know the law at this broad level of generality. ${ }^{240}$ Thus, Justice Scalia argued, something more must be necessary. The legal right "must have been 'clearly established' in a more particularized, and hence more relevant, sense: The contours of the right must be sufficiently clear that a reasonable official would understand that what he is doing violates that right." ${ }^{241}$ In order for a court to assess whether a right is clearly established, then, it must first understand what the official has done and what she knew when she did it. Those factors, in turn, are issues of historical fact.

In his dissent in Anderson, Justice Stevens underscored the importance of a factual inquiry. He noted that the Court did not "consider the possibility that the 'objective reasonableness' of the officer's conduct may depend on the resolution of a factual dispute."242 This was particularly likely to occur in circumstances where the relevant constitutional provision was stated at a high level of generality. ${ }^{243} \mathrm{He}$ observed that Harlow did not address the extent, if any, of immunity: when the official concedes that the constitutional right he is charged with violating was deeply etched in our jurisprudence, but argues that he reasonably believed that his particular actions comported with the constitutional command. ${ }^{244}$

Thus, according to Justice Stevens, Harlow immunity was not applicable to such claims. ${ }^{245}$ Although the capacity for factual conflicts in such cases would preclude the possibility of early termination on

238. See Anderson v. Creighton, 483 U.S. 635, 639 (1987).

239. See id.

240. See id.

241. Id. at 640 .

242. Id. at $655 \mathrm{~m} .10$ (Stevens, J., dissenting).

243. See id. at 648.

244. Il . at 655 . As argued below, because of the nature of modern constitutional doctrine, this encompasses most cases. See infra Part II.C.I.

245. See Anderson, 483 U.S. at 655 (Stevens, J., dissenting). 
summary judgment, he pointed out that officials could still pursue immunity claims at trial if their conduct was objectively reasonable. ${ }^{246}$

Applying this reasoning to Anderson, then, required a proper understanding of the nature of the dispute. ${ }^{247}$ Under the plaintiffs' characterization, the agent conducted an unlawful, warrantless search without probable cause and there was a clear rule of law prohibiting warrantless searches of homes without probable cause. ${ }^{248}$ If they were correct, and could establish the same at trial, it did not matter whether there were exigent circumstances-the search would still have been unreasonable under the Fourth Amendment. ${ }^{249}$ The agent, on the other hand, contended that not only was there probable cause, but also there were exigent circumstances that excused the warrant requirement, and that a reasonable officer might have concluded that there was both probable cause and exigent circumstances. ${ }^{250}$ Justice Stevens observed that the factual predicate for that argument was found in the agent's affidavits filed in support of his summary judgment motion. ${ }^{251}$ Accordingly, no resolution of the immunity claim could possibly occur until the plaintiffs had an opportunity to conduct discovery on these factual assertions. ${ }^{252}$

Lower federal courts occasionally have recognized the necessity for factual development, even in the post-Harlow world. The highly factsensitive nature of the reasonableness inquiry has been a signal to some courts that, in many circumstances, facts are critical to the immunity question. As the Seventh Circuit articulated in Elliott $v$. Thomas, "[i]t is impossible to know which 'clearly established' rules of law to consult unless you know what is going on." 253 Likewise, an earlier district court decision observed that the Harlow standard works "better in theory than in practice ... because it often will be impossible to assess the objective reasonableness of the defendant's conduct without a resolution of the factual disputes surrounding the incident from which the action arises." 254

246. See id. at 655 n.10.

247. See id.

248. See id. at 656 .

249. See id. at 657 .

250. See id. at 657-58.

251. See id. at 658 .

252. See id.

253. Elliott v. Thomas, 937 F.2d 338, 342 (7th Cir. 1991) (citations omitted); see also Act Up!/Portland v. Bagley, 988 F.2d 868, $873 \&$ n.3 (9th Cir. 1993) (finding that determination of reasonable suspicion under the Fourth Amendment requires factual inquiry).

254. McGaughey v. City of Chicago, 664 F. Supp. 1131 , 1138 (N.D. Ill. 1987), vacated in part, 690 F. Supp. 707 (N.D. Ill. 1988). The author was a law clerk to the judge who wrote the original MeGaughy opinion at the time it was decided. See SCHWARTZ \& KIRKLIN, supra note 227, $\$ 9.25$ (citing McGaughey and concluding that "there are often sharp factual issues between the 
The only context in which the issue of the clearly established nature of the legal rights at stake can be considered to be a pure question of law is when the Court truly breaks new ground and develops, in common-law fashion, an entirely new constitutional doctrine. That is, the basic policies underlying qualified immunity surely can be understood to support immunity when it is unclear that the law governs an area of governmental action. In his dissent in Anderson, Justice Stevens asserted that Harlow must necessarily be limited in scope to precisely these situations, where immunity is warranted "based on the tentativeness or nonexistence of the constitutional rule allegedly violated by the officer....,255 Thus, for example, were a constitutional tort plaintiff to assert that a government official violated her constitutional right to "happiness," qualified immunity would protect the official from liability. Moreover, because the newness or originality of such a claim would appear on the face of the complaint, the defendant would also be able to avoid the burdens of litigation. In most cases, however, qualified immunity arises not because an entirely new area of law is emerging but because the consequences of applying existing constitutional principles to a particular set of facts are unclear. ${ }^{256}$

Perhaps concern about the burdens generated by the factual component of qualified immunity has prompted the Supreme Court's recent attention to the scope of interlocutory appeals of qualified immunity denials. In Johnson v. Jones, ${ }^{257}$ the Court held that defendants may not take interlocutory appeals from denials of qualified immunity claims if the trial court's sole reason for rejecting the claim is the existence of a genuine issue of material fact. ${ }^{258}$ In contrast, in Behrens v. Pelletier ${ }^{259}$ the Court held that in cases in which the qualified immunity appeal is not based on a factual dispute, a defendant may assert the defense in multiple interlocutory appeals, ${ }^{260}$ thus eradicating de-

parties, the resolution of which are necessary to determine whether the defendant official violated clearly established federal law").

255. Anderson, 483 U.S. at 659 (Stevens, J., dissenting) (citing Mitchell v. Forsyth, 472 U.S. 511,535 n.12 (1985)).

256. Of course, the distinction between a purely new rule and the application of a clearly established rule to different circumstances is itself a blurry one. See Butler v. McKellar, 494 U.S. 407, 412-13 (1990) (recognizing that in context of determining whether habeas corpus petitioner has asserted a new rule for jurisdictional purposes, the federal courts' inquiries will be more difficult in cases where the new legal rule has developed based on an extension of reasoning from earlier cases); id. at 418 (Brennan, J., dissenting) ("Because constitutional interpretation is an evolutionary process, the analytical distinction between legal rules 'prevailing' at the time of conviction and 'new' legal rules is far from sharp.").

257. 515 U.S. 304 (1995).

258. See id. at $317-20$.

259. 516 U.S. 299 (1996).

260. See id. at 313. The Behrens decision also resolved previously open issues regarding in- 
cisions, adopted by some federal circuits, that limited defendants to one interlocutory appeal on qualified immunity claims. ${ }^{261}$ Finally, the Court recently decided that federal law does not require state appellate courts to provide interlocutory appeals from the denial of qualified immunity defenses. ${ }^{262}$ What is noteworthy about these decisions is not their alteration of qualified immunity law, but their reflection of the continuing burdens facing the federal court system in implementing this fact-based doctrine.

\section{The Confluence of the Qualified Immunity Standard with Substantive Constitutional Law}

In addition to the factual nature of the basic reasonableness inquiry imposed by the qualified immunity standard, another aspect of the qualified immunity doctrine ensures that facts will play an important role in the resolution of most immunity inquiries. Under the Harlow standard, courts not only must evaluate the reasonableness of the defendant official's conduct with reference to some set of facts, but also must measure those facts against the substantive constitutional law existing at the time of that conduct. Thus, even if there is some agreement about what factual scenario existed at the time the defendant acted, courts must assess whether a reasonable official would have understood that conduct to be unconstitutional.

Some commentators have observed that qualified immunity claims are more likely to generate factual disputes that cannot be resolved on summary judgment in certain substantive areas of constitutional law that are particularly susceptible to highly fact-specific inquiries. ${ }^{263}$

terlocutory appeals of the denial of qualified immunity in cases in which the plaintiffs complaint combines claims for equitable relief and damages and in cases in which the denial of qualified immunity concerns only one of a set of multiple damage claims. See generally Jody Beal, Qualyied Immunily and the Right to Immediate Appeal, 63 UMKC L. REV. 229, 246-48 (1994) (arguing pre-Behrens for expansion of interlocutory appeals of qualified immunity denials, even in circumstances in which appealable and nonappealable issues are combined).

261. See, e.g., Pelletier v. Federal Home Loan Bank, 968 F.2d 865, 870-71 (9th Cir. 1992) (holding that government official cannot pursue repeated interlocutory appeals on qualified immunity claim), rev'd sub nom. Behrens v. Pelletier, 516 U.S. 299 (1996); Abel v. Miller, 904 F.2d 394, 397 (7th Cir. 1990) (limiting official defendants to one interlocutory appeal of denials of qualified immunity); Unwin v. Campbell, 863 F.2d 124, 132 n.5 (1st Cir. 1988) (same).

262. See Johnson v. Fankell, 117 S. Ct. 1800, 1802 (1997).

263. See David J. Ignall, Making Sense of Qualified Immunity: Summary Judgment and Issues for the Trier of Fact, 30 CAL. W. L. REv. 201, 202 (1994) (arguing that in claims against police officers under Fourth Amendment and against prison officials under Fourteenth Amendment, "the standard for determining liability is vague enough that ... [defendants] often are not able to obtain a pretrial determination of their immunity"); Kathryn R. Urbonya, Problematic Standards of Reasonableness: Qualified Immunity in Section 1983 Actions for a Police Officer's Use of Excessive Force, 62 TEMP. L. REV. 61, 96-114 (1989) (contending that qualified immunity standard does not operate well in conjunction with claims of excessive force by law enforcement officers because Fourth Amendment reasonableness standard duplicates qualified immunity reason- 
Other commentators, ${ }^{264}$ and many lower courts, ${ }^{265}$ have also found special problems associated with factual disputes in cases in which the plaintiff must prove as an element of the underlying constitutional violation that the defendant acted with a particular state of mind. As argued below, however, the factual nature of qualified immunity is nearly universal because the modern Supreme Court increasingly has chosen to articulate substantive constitutional law in the form of open-ended standards or "balancing" tests. ${ }^{266}$ In conjunction with the qualified immunity reasonableness standard, constitutional balancing tests heighten the opportunities for factual conflicts on immunity claims.

\section{Qualified immunity and constitutional standards}

In the modern constitutional era, the Court defines the scope of substantive constitutional law by articulating balancing tests-broad, open-ended standards that define the scope of most individual constitutional rights. ${ }^{267}$ Rather than providing a set of bright-line rules

ableness standard).

264. See Karen M. Blum, Heightened Pleading: Is There Life After Leatherman?, 44 CATH. U. L. REv. 59, 60-61 (1994) [hereinafter Blum, Heightened Pleading] (detailing lower federal courts' disparate treatment of special pleading requirements when state of mind is at issue); Stephanie E. Balcerzak, Note, Qualified Immunily for Government Officials: The Problem of Unconstilutional Purpose in Civil Rights Litigation, 95 YALE L.J. 126, 127 (1985) (arguing that qualified immunity standard must be restructured to separate legal question of official's immunity from state of mind inquiry).

265. See, e.g., Branch v. Tunnell, 937 F.2d 1382, 1387 (9th Gir. 1991) (requiring plaintiff to meet heightened pleading standard in response to qualified immunity claim where proof of constitutional violation depends on official's state of mind); Kimberlin v. Quinlan, 6 F.3d 789, 793 (D.C. Cir. 1993) (same), vacated on other grounds, 515 U.S. 321 (1995); Whitacre v. Davey, 890 F.2d 1168, 1171 (D.C. Cir. 1989) (same).

266. See infra note 267 and accompanying text (explaining expansion of balancing tests).

267. See, e.g., Skinner v. Railway Labor Executives' Ass'n, 489 U.S. 602, 619 (1989) (explaining that drug and alcohol testing should be judged using the Fourth Amendment special needs test, which entails balancing individual privacy against government interest in testing); Mathews v. Eldridge, 424 U.S. 319, 335 (1976) (explaining that procedural due process analysis requires balancing of the private interest, the risk of an erroneous deprivation of the private interest, and the government's interest). Commentators have observed the Court's shift from categorical rules to standards incorporating balancing tests. See T. Alexander Aleinikoff, Constilutional Law in the Age of Balancing, 96 YALE L.J. 943, 951-52 (1987) (explaining Supreme Court's shift toward balancing approach in mid-twentieth century); David L. Faigman, Madisonian Balancing: A Theory of Constitutional Adjudication, 88 NW. U. L. REv. 641, 642-43 (1994) (explaining Supreme Court's increasing reliance on balancing methodology, but offering critique of its methodology). But see Kathleen M. Sullivan, The Supreme Court, 1991 TermForeword: The Justices of Rules and Standards, 106 HARV. L. REV. 22, 60, 69-70 (1992) [hereinafter Sullivan, Foreword] (arguing that categorical approaches have not been completely replaced by balancing tests, as evidenced by the rules/standards debates of the 1991 Supreme Court term, and that the Court instead moves between categorical and balancing approaches depending upon the individual Justices' jurisprudential philosophies); Kathleen M. Sullivan, Post-Liberal Judging: The Roles of Categorization and Balancing, 63 U. CoLO. L. Rev. 293, 295 (1992) (explaining that "categorical and balancing approaches oscillate"). Professor Sullivan does concede, however, that balancing has "been in ascendancy." Id. at 296. There are counterexamples of the balancing trend as well. See, e.g., Lucas v. South Carolina Coastal Council, 505 
divining predetermined results for particular types of government conduct or regulation, balancing tests identify general criteria for constitutional decisionmaking, but leave great discretion to the decisionmaker to apply these criteria to the individual circumstances of each case. ${ }^{268}$ When it creates balancing tests, the Court instructs lower courts to explicitly "weigh" individual rights (e.g., privacy, equality, speech) against governmental interests (e.g., public health, social welfare, social order). ${ }^{269}$ The balancing metaphor symbolizes the evaluation of the relative substantive importance of these often competing values. Balancing tests, like all legal standards, necessitate individualized, context-specific determinations of constitutional rights because the quantum of interests may vary substantially from case to case, even under the same constitutional provision. ${ }^{270}$ In each case, the decisionmaker determines the outcome by evaluating which interest or value is "weightier."271

As some have observed, balancing tests have become the predominant mode of articulating substantive constitutional doctrine in the modern era. ${ }^{272}$ The Court has extended them to the broad range of constitutional rights that can be raised in constitutional tort cases to which qualified immunity applies. ${ }^{273}$ Indeed, constitutional balancing tests pervade the substantive constitutional landscape.

In many areas of Fourth Amendment law, the Court has established various balancing tests that dictate the outcome of individual cases. $^{274}$ A prime example of balancing is the Court's definition of the "reasonableness" of official conduct that may violate the Fourth Amendment's prohibition of unreasonable searches and seizures. In particular, under the "special needs" doctrine, the Court has estab-

U.S. 1003, 1015 (1992) (stating that balancing of interests not required under Takings Clause when government regulation denies landowner all "economically beneficial or productive use of land"); Employment Div. v. Smith, 494 U.S. 872, 882-90 (1990) (holding that balancing of interests is not required when party seeks religious exemption from generally applicable criminal prohibition under First Amendment's Free Exercise Clause). Professor Aleinikoff's seminal work in the area of constitutional balancing provides a more complete account of balancing as a form of constitutional decisionmaking. See generally Aleinikoff, supra, at 943-1005.

268. See Sullivan, Foreword, supra note 267, at 58-59 (providing detailed account of constitutional balancing process); see also Chen, supra note 14, at 298-302 (comparing constitutional rules with balancing tests).

269. See Aleinikoff, supra note 267 , at $946-47$ (explaining interest balancing); see also Chen, supra note 14 , at 302 (same).

270. See Chen, supra note 14, at 302 (explaining balancing in general)

271. See Aleinikoff, supra note 267 , at 946 (discussing the scales metaphor).

272. See id. at 944 (noting rise and spread of balancing tests); Faigman, supra note 267, at 642 (noting Supreme Court's increased reliance on balancing).

273. See Chen, supra note 14, at 317 (discussing balancing in constitutional tort cases).

274. See generally Nadine Strossen, The Fourth Amendment in the Balance: Accurately Selling the Scales Through the Least Intrusive Allernative Analysis, 63 N.Y.U. L. REv. 1173, 1178-84 (1988) (discussing Court's adoption of various balancing tests in Fourth Amendment context). 
lished a balancing test to evaluate the reasonableness of warrantless government searches that are not for criminal law enforcement purposes. ${ }^{275}$ Examples of such searches include government employers conducting urine testing of employees and job applicants to detect the presence of drug metabolites, and school officials looking through lockers and desks for various forms of contraband. In such cases, the Court has directed that the constitutionality of the search should be measured by weighing the government's interests in conducting the search with neither a warrant nor probable cause against the intrusion on the individual's privacy. ${ }^{276}$ The "reasonableness" of a search, according to Fourth Amendment case law, must take into account "all of the circumstances surrounding the search or seizure ...."277 This requires the decisionmaker in a given case to precisely weigh the government interests against the privacy interests of the person searched.

Balancing tests have spread into many other areas of constitutional doctrine beyond the Fourth Amendment "reasonableness" standard. Under the free speech doctrine, for instance, the Court has adopted balancing tests to define the extent to which a government employer violates the First Amendment rights of employees when it takes adverse action against an employee based on her speech. ${ }^{278}$ While government employees have a right to engage in speech on "'matters of public concern," the Court has established that this right must be weighed against the government's interest in maintaining an efficiently operating workplace. ${ }^{279}$

Moreover, in Waters $v$. Churchill, ${ }^{280}$ the Court recently added another layer to the reasonableness inquiry in employee speech cases. The Court held that when a public employee alleges that she was

275. See Skinner v. Railway Labor Executives' Ass'n, 489 U.S. 602, 619 (1989) (noting that Court will balance governmental and private interests in special needs cases).

276. See id. For an excellent discussion of the transformation of Fourth Amendment jurisprudence from a rule-based decisionmaking model to a particularized interest-balancing model based on pragmatist theory, see Morgan Cloud, Pragmatism, Pasitivism, and Principles in Fourth Amendmenl Theory, 41 UCLA L. REv. 199, 223-68 (1993). For a critical view of the implementation of rules under the Fourth Amendment, see Albert W. Alschuler, Bright Line Fever and the Fourth Amendment, 45 U. PITT. L. REV. 227, 231 (1984) (arguing that bright-line rules for regulating police conduct may lead to disregard of important values and may, ironically, confuse rather than clarify the law).

277. Skinner, 489 U.S. at 619 (quoting United States v. Montoya de Hernandez, 473 U.S. 531,537 (1985)).

278. See Pickering v. Board of Ed., 391 U.S. 563, 568 (1968) (stating that there must be balancing of interests between employee and employer).

279. See Connick v. Myers, 461 U.S. 138, 142 (1983) (quoting Pickering, 391 U.S. at 568); see also Chen, supra note 14, at 304 (describing how balancing under the Connick/Pickering doctrine is used both to evaluate whether employee's speech is constitutionally protected and, if it is, whether government's interest outweighs the speech interest).

280. 511 U.S. 661 (1994). 
terminated or otherwise punished for engaging in protected speech, but the government employer's knowledge of the content of the speech is disputed, the employer's knowledge must be evaluated by the facts "as the employer reasonably found them to be." ${ }^{281}$ Under existing law, a public employer who mistakenly fires an employee after concluding that she made a disruptive or insubordinate statement may violate the employee's First Amendment rights if her statement was about a matter of public concern. ${ }^{282}$ But under Waters, the employer may evade liability if she reasonably, but erroneously, believed that the employee's speech was not protected speech about a matter of public concern. ${ }^{283}$

Case law interpreting the Eighth Amendment ${ }^{284}$ provides another example of the pervasiveness of constitutional reasonableness standards. In Farmer v. Brennan, ${ }^{285}$ the Supreme Court was called upon to clarify the scope of the Eighth Amendment's "cruel and unusual punishments" provision. The plaintiff was a transsexual who claimed that prison officials failed to adequately protect him when they either transferred him or placed him in the general prison population of a penitentiary despite knowledge that the penitentiary had a violent environment and a history of inmate assaults, and despite knowledge that the plaintiff would be particularly vulnerable to sexual attack by other inmates because of his transsexual status. ${ }^{286}$ The Court had previously held that a prisoner who made such a claim must prove that the prison officials acted with "deliberate indifference" to the prisoner's safety or other security needs. ${ }^{287}$

The central issue in Farmer was whether the existing deliberate indifference standard was subjective or objective. ${ }^{288}$ The plaintiff claimed that the test should be objective, so that he need prove only that the defendants either knew or reasonably should have known of the danger presented by the prison environment. ${ }^{289}$ As the Court noted, this standard mirrors the general civil law standard for recklessness. ${ }^{290}$ The Court rejected that argument, however, adopting instead the government's position that a prisoner must prove that a

281. Id. at 677.

282. See Connick, 461 U.S. at 142.

283. See Walers, 511 U.S. at 677.

284. U.S. CONST. amend. VIII ("Excessive bail shall not be required, nor excessive fines imposed, nor cruel and unusual punishments inflicted.").

285. 511 U.S. 825 (1994).

286. See id. at 830-31.

287. See Estelle v. Gamble, 429 U.S. 97, 104 (1976).

288. See Farmer, 511 U.S. at 837.

289. See id. at $837 \&$ n.5.

290. Ser id. at 837. 
prison official knew of and disregarded "an excessive risk to inmate health or safety" in order to establish an Eighth Amendment violation. ${ }^{291}$ In a portion of the opinion clarifying the scope of this new standard, the Farmer Court observed that even prison officials who subjectively know of a substantial risk to an inmate's health or safety may not be in violation of the Eighth Amendment "if they responded reasonably to the risk, even if the harm ultimately was not averted."202 The Court went on to explain that " $[w]$ hether one puts it in terms of duty or deliberate indifference, prison officials who act reasonably cannot be found liable under the Cruel and Unusual Punishments Clause." ${ }^{293}$

Thus, the Court often invokes a substantive reasonableness standard as a metric for unconstitutional behavior. What is more, the substantive constitutional standard need not formally be phrased in the form of a "reasonableness" test for balancing to occur. The Court acknowledged this point in Anderson v. Creighton. ${ }^{294}$ In Anderson, a dispute arose concerning whether law enforcement officers should be entitled to claim qualified immunity, or if they were already sufficiently protected by the Fourth Amendment's "reasonableness" standard. ${ }^{295}$ The plaintiffs argued that qualified immunity should not be available to officers accused of such violations because the Constitution already allows for reasonable, but mistaken, judgments about government officers' searches and seizures. ${ }^{296}$ To permit the defendant to assert qualified immunity, they argued, would be to create a logically impossible category of actions that are "reasonably unreasonable," in that they are unreasonable in terms of substantive Fourth Amendment law, but are reasonable violations of that law for purposes of qualified immunity. ${ }^{297}$ The majority quickly disposed of the plaintiffs' argument, noting that the Court already recognized the applicability of qualified immunity to Fourth Amendment cases, and dismissing the double reasonableness standard as a semantic coincidence. ${ }^{298}$ In rejecting the plaintiffs' argument that a public official cannot be reasonably unreasonable, Justice Scalia asserted that similar arguments could be made concerning virtually all individual constitutional rights.

291. See id.

292. Id. at 844 .

293. Id. at 845 .

294. 483 U.S. 635 (1987).

295. See id. at 642-43.

296. See id. at 643 .

297. See id.

298. See id. at 643-44. 
The fact is that, regardless of the terminology used, the precise content of most of the Constitution's civil-liberties guarantees rests upon an assessment of what accommodation between governmental need and individual freedom is reasonable, so that the Creightons' objection, if it has any substance, applies to the application of Harlow generally. ${ }^{209}$

Justice Scalia correctly recognized that all balancing tests, however characterized, ultimately rest on a determination of the reasonableness of the government actor's conduct. But his point proves too much. He fails to recognize that the argument against applying the qualified immunity reasonableness standard to substantive constitutional standards has wide, if not universal, application. ${ }^{300}$

Indeed, Justice Stevens acknowledged this form of constitutional directive in his dissent in Anderson. Criticizing the majority's application of the qualified immunity doctrine to a Fourth Amendment "reasonableness" claim, Justice Stevens observed that Harlow immunity claims may not be applicable if an official's conduct is not susceptible to a determination that it violated clearly established law because it is stated at a high level of abstraction:

[A]n official's conduct is not susceptible to a determination that it violated clearly established law because it is regulated by an extremely general and deeply entrenched norm, such as the command of due process or probable cause. The principle is clearly established, but whether it would brand the official's planned conduct as illegal often cannot be ascertained without reference to facts that may be in dispute. ${ }^{301}$

Justice Stevens's proposition is correct, but it does not go far enough. Under modern constitutional doctrine, commands such as "due process" and "probable cause" are the rule, not the exception. Thus, under the balancing tests regime, the constitutional right at stake in any given case will be stated as a broad general principle, and at the same time will be subject to infinite factual variations.

Accordingly, the central problem with the application of qualified

299. Id. (emphasis added). For a critical view of Justice Scalia's statement that reasonableness standards predominate in constitutional doctrine, see Urbonya, supra note 263 , at 88 \& n.201 (arguing that the Court's generalization about constitutional reasonableness standards is "flawed" and is inconsistent with the Court's "tradition of carefully defining and distinguishing the standards for liability under various amendments").

300. See Chen, supra note 14, at 315 (arguing that Justice Scalia's opinion suggests that all constitutional doctrines are essentially premised on government officials' reasonableness).

301. Anderson, 483 U.S. at 656 n.12 (Stevens, J., dissenting) (citations omitted). Justice Stevens similarly argued that Harlow's reasoning did not necessarily extend to cases "in which both the constitutional command and an exception to the rule for conduct that responds to a narrowly defined category of factual situations are clearly established, and the dispute is whether the situation that the officer confronted fits within the category." Id. at 651 n.3. 
immunity to constitutional tort claims when the underlying violation is defined by a balancing test is that specific facts will almost always be necessary to make an immunity ruling. This undermines the purposes of the qualified immunity doctrine because it creates a wide range of cases in which disputes center on the application of the general framework of constitutional law to an unclear set of facts.

\section{Qualified immunity and constitutional rules}

The factual nature of qualified immunity might not be as critical if the doctrine could be applied more coherently to clear constitutional rules. But for two reasons, immunity doctrine does not work in this context either. First, as just discussed, there are few clear constitutional rules in the modern era. Because most substantive constitutional doctrine is now articulated as standards or balancing tests, ${ }^{302}$ the application of qualified immunity to cases asserting clear constitutional rules should be of limited interest or concern. Second, when clear constitutional rules are applicable, the qualified immunity doctrine has no logical application anyway. ${ }^{303}$ The clearer the constitutional rule in a given situation, the less likely it is that a reasonable official could mistakenly violate such a rule. ${ }^{304}$ Furthermore, even in the limited circumstances when qualified immunity is logically relevant to such claims, factual disputes are as likely to arise as they are when immunity is applied to a constitutional standard. ${ }^{305}$

The problem can best be understood by considering some simple examples. A fairly clear constitutional rule exists under the Fourth Amendment. ${ }^{306}$ In Payton v. New York, ${ }^{307}$ the Supreme Court established that police officers may not enter a suspect's home to make an arrest unless they have a valid arrest warrant. ${ }^{308}$ A warrantless entry to execute an in-home arrest is in most circumstances unconstitutional, as is any search conducted incident to such an arrest. ${ }^{309}$ Although exceptions to the Payton rule exist, it is applicable in many situations. If confronted with such a situation, an officer can hardly claim that a

302. This point has been exhaustively explored by numerous scholars. See, e.g., Aleinikoff, supra note 267, at 995-96; Chen, supra note 14, at 324; Faigman, supra note 267, at 642-43; Sullivan, Foreword, supra note 267 , at $60-62$.

303. See Chen, supra note 14 , at 308 (explaining that only when there are "unclear exceptions to or limitations on the rule's application does qualified immunity make sense").

304. See id.

305. See id. at 308-09 (explaining that courts must consider the factual circumstances that "constitute reasonableness and unreasonableness" in context).

306. U.S. CONST. amend. IV.

307. 445 U.S. $573(1980)$.

308. See id. at 589-90.

309. See id. at 598-601. 
mistaken warrantless entry to execute an in-home arrest is reasonable for qualified immunity purposes because the rule is so clear and ordinarily it should be easy to understand when it applies. ${ }^{310}$

Qualified immunity is similarly illogical in the context of brightline constitutional rules involving intentional misconduct by public officials. $^{311}$ Because neither $\S 1983$ nor Bivens contains a state of mind element, state of mind requirements are derived from the underlying substantive constitutional doctrine. ${ }^{312}$ Thus, while a Fourth Amendment claim is usually evaluated in terms of a law enforcement officer's "reasonableness," the Equal Protection Clause must be supported by evidence of the defendant's intent to discriminate because of the victim's race. ${ }^{314}$ Certain First Amendment claims also turn on intent, ${ }^{315}$ and many other constitutional doctrines embody a state of mind element. ${ }^{316}$

The overlay of qualified immunity adds a conceptually problematic dimension to constitutional tort claims with state of mind issues. The qualified immunity standard suggests that courts should evaluate a defendant's conduct against a hypothetical official's reasonableness. The problem with asserting the defense when the underlying constitutional tort includes an intent element is that the "objective" qualified immunity test doesn't make much sense. Suppose that a public official is alleged to have demoted an employee on the basis of race. The employee sues under $\S 1983$, claiming a denial of equal protection of the law under the Fourteenth Amendment (or, if the situation involves a federal employee, she would allege a Fifth Amendment equal protection violation under Bivens). As required under current equal protection doctrine, the employee alleges facts that suggest the

310. See Chen, supra note 14, at 325-26 (making a similar argument about the application of qualified immunity to a clear First Amendment rule forbidding government discrimination based on the content of speech).

311. See infra notes $314-15$ and accompanying text.

312. See Farmer v. Brennan, 511 U.S. 825, 837 (1994) (implicitly recognizing that the underlying constitutional standard defines requisite state of mind in Bivens actions); Parratt $v$. Taylor, 451 U.S. 527, 534 (1981) (holding that $\$ 1983$ has no state of mind requirement), overruled on olher grounds, Daniels v. Williams, 474 U.S. 327 (1986).

313. See, e.g., New Jersey v. T.L.O., 469 U.S. 325,337 (1985).

314. See Washington v. Davis, 426 U.S. 229,239 (1976).

315. See Kimberlin v. Quinlan, 6 F.3d 789, 795 (D.C. Cir. 1993), vacaled on other grounds, 515 U.S. 321 (1995).

316. See, e.g., Farmer, 511 U.S. at 837 (requiring that plaintiff suing for imposition of cruel and unusual punishment under the Eighth Amendment demonstrate that defendant acted with "deliberate indifference," meaning that she had subjective knowledge that a substantial risk of serious harm to plaintiff existed, but disregarded that risk). See generally 10A CHARLES AiAn Wright et AL., Federal Practice AND Procf.dure § 2732.2, at 340-53 (2d ed. 1983) (explaining that courts deny summary judgment in cases involving constitutional doctrines when a necessary element of the claim for relief is a determination of state of mind). 
official made the decision to demote her because of her race. ${ }^{317}$

The defendant's summary judgment motion in such a case would argue that, even if the public official violated the Equal Protection Clause, no reasonable official in the same position would have understood that such treatment of the plaintiff violated a clearly established right. Conceptually, this makes no sense. When a clear intentbased rule is in place, the outcome of a case is entirely dependent upon the truth of the historical fact of the defendant's state of mind. If the defendant acted with the intent to harm the plaintiff because of her race, no court would find that a reasonable official could believe that there might be some circumstance that made such an act permissible under established law. If the defendant did not have the requisite intent at the time of her act, she has not committed a substantive equal protection violation, and immunity is not even an issue. Thus, immunity here becomes nothing more than a variation on the "I didn't do it defense" (or, perhaps, the "I didn't think it" defense), which is highly susceptible to a basic factual dispute that is irresolvable without trial. Indeed, at least one lower court has recognized the incompatibility of qualified immunity in cases when similarly clear rules are applicable. ${ }^{318}$

In any event, to the limited extent that the qualified immunity reasonableness standard could logically be applied to an intent-based constitutional violation, it would likely lead to some sort of factual dispute. First, the very nature of the underlying issue is highly likely to raise disputes over the historical fact of the defendant's state of mind. In his dissent in Anderson, Justice Stevens observed that Harlow immunity might be inapplicable in state of mind cases because such cases would necessarily turn on an inquiry into the official's state of mind, thus making summary judgment difficult, if not impossible. ${ }^{319}$ This scenario is highly probable. In most cases of this sort, the defendant will deny the requisite intent and, providing there is some circumstantial evidence of discriminatory intent, a genuine factual issue would arise. ${ }^{320}$

317. See Washingtom, 426 U.S. at 239.

318. See Auriemma v. Rice, 910 F.2d 1449, 1457 (7th Cir. 1990) ("Any police chief who thought he could demote and promote only along allegedly clear racial lines could not be a reasonable police chief.").

319. Anderson v. Creighton, 483 U.S. 635, 656 n.12 (1987) (Stevens, J., dissenting).

320. The problem associated with qualified immunity in the context of bright-line constitutional rules explains in part the difficulty courts have had in enforcing the doctrine in the context of constitutional tort claims in which state of mind is an element of the plaintiff's claim. The state of mind element from constitutional law imports the very inquiry into motivation that the Harlow Court sought to avoid. Arguments concerning a party's state of mind may be diffcult to resolve without substantial discovery. Even after discovery, irresolvable disputes might 
Second, even under conventional summary judgment doctrine, not incorporating the additional complication of qualified immunity, claims involving a party's state of mind are generally disfavored on summary resolution because the defendant's credibility is often an issue. $^{321}$ In the qualified immunity context, the potential for state of mind disputes also may preclude summary resolution. In fact, Harlow explicitly eliminated the "subjective" component of qualified immunity in order to rid the doctrine of fact-specific, discovery-

exist over evidence concerning a party's state of mind because the outcome may depend on witness credibility. Because discovery and extensive motion practice arguably undermine the goal of early disposition of constitutional tort claims, some federal appellate courts have adopted "heightened pleading" requirements in such cases, requiring plaintiffs to plead facts concerning the defendant's state of mind with greater specificity than would ordinarily be required to survive a motion to dismiss under federal pleading rules. See, e.g., Elliott v. Perez, 751 F.2d 1472, 1473 (5th Cir. 1985); Kimberlin v. Quinlan, 6 F.3d 789, 793-94 (D.C. Cir. 1993), vacaled on other grounds, 515 U.S. 321 (1995).

The Supreme Court has twice granted certiorari to address the heightened pleading rule, but has resolved both cases on other grounds, thus leaving lower courts without guidance as to the propriety of imposing this additional burden on civil rights plaintiffs. Compare Kimberlin v. Quinlan, 513 U.S. 1123 (1995) (granting certiorari), with Kimberlin v. Quinlan, 515 U.S. 321 (1995) (vacating and remanding for reconsideration in light of Johnson v. Jones, 515 U.S. 304 (1995)); Siegert v. Gilley, 498 U.S. 918 (1990) (granting certiorari), with Siegert v. Gilley, 500 U.S. 226, 232-35 (1991) (holding that plaintiff failed to allege the violation of any constitutional right). For a novel approach regarding the heightened pleading standard in qualified immunity cases, see Schultea v. Wood, 47 F.3d 1427, 1433-34 (5th Cir. 1995) (en banc) (explaining that while a reply normally is not required under Rule 7 of the Federal Rules of Civil Procedure, in some cases (such as this one) the court may order the plaintiff to reply to the defense of qualified immunity when it would be helpful to test the sufficiency of the claim).

Academic commentary is beginning to address this highly problematic area of qualified immunity law. See, e.g., Blum, Heightened Pleading, supra note 264, at 92-94 (arguing that a special pleading burden should not be instituted); Balcerzak, supra note 264, at $146-47$ (proposing a restructuring of the qualified immunity inquiry); Eric Harbrook Cottrell, Note, Civil Righls Plainliffs, Clogged Courls, and the Federal Rules of Civil Procedure: The Supreme Court Takes A Look at Heightened Pleading Standards in Leatherman v. Tarrant County Narcotics Intelligence \& Coordination Unit, 72 N.C. L. REv. 1085, 1085-86 (1994) (maintaining that courts should resort to "summary judgment and discovery control" rather than heightened pleading standards); Gary T. Lester, Comment, Schultea II-Fifth Circuit's Answer To Leatherman-Rule 7 Reply: More Questoons Than Answers In Civil Rights Cases?, 37 S. TEX. L. REv. 413, 474-75 (1996) (noting that the reasons for requiring heightened pleading may be persuasive, but that courts must function under the Rules as they exist today).

321. See Poller v. Columbia Broad. Sys., 368 U.S. 464, 473 (1962) (stating that summary judgment should be used "sparingly" in cases where motive and intent "play leading roles" because credibility can be appraised only upon cross-examination). For a general discussion of problems assaciated with the application of summary judgment law to disputes over state of mind, see David A. Sonenshein, Stale of Mind and Credibility in the Summay Judgment Context: A Beller Approach, $78 \mathrm{NW}$. U. L. REv. 774, 786-95 (1983) (noting the difficulties in determining whether such cases merit "special treatment" under summary judgment law). While many modern courts often cite the general rule that summary judgment is inappropriate for resolution of state of mind issues, others have criticized the blanket presumption that state of mind issues cannot be resolved in such a manner. See id. at 794 (explaining that some courts apply the summary judgment rule to any factual matter in the same way, even when it is applied to state of mind issues). One commentator, however, has pointed out that concerns over the use of summary judgment in resolving state of mind issues should not excuse a plaintiff from identifying evidence, after discovery, that would create a genuine issue of fact on the intent issue. See id. at 788-90. 
necessitating, state of mind disputes. ${ }^{322}$

The only time that qualified immunity makes sense in the context of bright-line constitutional rules is when an official can argue that it was not clear whether the relevant rule was applicable. ${ }^{323}$ For instance, in the equal protection example, an official could argue that a reasonable official would not have understood that her conduct constituted state action, and therefore would not have understood that the Fourteenth Amendment was applicable to that conduct. ${ }^{324}$ In other contexts, an official could argue that a reasonable official might have believed an exception to the bright-line rule was applicable. $^{325}$ Moreover, in a case implicating the legal standards regarding mixed motives, at least one court has found that qualified immunity may protect an official who has both legitimate and invidious motives for causing a particular deprivation. ${ }^{326}$

In the above examples, however, the analysis simply revolves back to the problem of the fact-based nature of qualified immunity, but in the context of standard-like exceptions to clear constitutional rules. ${ }^{327}$ Accordingly, when questions concerning the applicability of a clear rule are at issue, the same problems discussed earlier regarding constitutional standards arise, and the qualified immunity claim is as inherently fact-based as if the underlying constitutional directive were a balancing test. ${ }^{328}$

322. See Harlow v. Fitzgerald, 457 U.S. 800,816 (1982).

323. See Chen, supra note 14 , at 326 (arguing that although a government official cannot successfully contend that a reasonable official would have been ignorant of a constitutional rule, she may be able to argue that a reasonable official would have been confused about the rule's applicability).

324. See, e.g., Rambo v. Daley, 68 F.3d 203, 206 (7th Cir. 1995) (rejecting officials' claim that they were entitled to qualified immunity because it was unclear whether they were acting in an official capacity when they harmed the plaintiff), cert. denied, 116 S. Ct. 1546 (1996); Luria Bros. \& Co. v. Allen, 469 F. Supp. 575, 578 (W.D. Pa. 1979) (denying private defendant's qualified immunity defense, which asserted that it was unclear whether a private individual could violate the Constitution by seizure of property pursuant to a state landlord/tenant statute). For a general discussion of the applicability of qualified immunity to constitutional rules, and an explanation of the impact of the defense on the decision to adopt a clear rule, see Chen, supra note 14 , at $324-32$.

325. See Chen, supra note 14, at 326 (noting that an official might argue that she mistakenly believed that certain speech fell under an obscenity exception to a rule against content discrimination).

326. See Foy v. Holston, 94 F.3d 1528, 1535 (11th Cir. 1996) (explaining that court may grant qualified immunity when the summary judgment record showed both lawful and discriminatory motive may have been present).

327. See generally Chen, supra note 14, at 320-24 (describing how constitutional rules can turn into standard-like directives when the Court adopts open-ended standards to define the circumstances in which the rule is to be applied, the scope of the rule's application, or the exceptions to the rule's application).

328. See supra notes 267-301 and accompanying text. 


\section{SUMMARY JUDGMENT AS GATEKEEPER}

At roughly the same time the Court was transforming qualified immunity to limit the social costs of constitutional tort litigation, it was also modifying the law of summary judgment, the procedural vehicle designated for adjudicating the immunity defense. Modern federal pleading rules require only that the pleadings contain a "short and plain statement of the claim,",329 and be legally sufficient to state a claim upon which relief could be granted. ${ }^{330}$ Widely known as "notice" pleading, this regime was ushered in by the Federal Rules of Civil Procedure, which were specifically designed to deemphasize technical pleading disputes, to direct federal litigation toward discovery, and to focus attention on the merits. ${ }^{331}$ Given these relatively lenient pleading rules, many claims survive the preliminary stages of the federal claim-screening process even when the parties asserting them may not be able to prevail at trial. ${ }^{332}$ As a partial accommodation to account for the new pleadings rules, the drafters of the Federal Rules adopted the summary judgment device to filter out insubstantial and unmeritorious claims that survived the pleading stage. ${ }^{333}$

329. FED. R. CIV. P. 8(a) (2). The Rules establish exceptions to this general pleading rule for specific substantive claims such as fraud, see FED. R. CIV. P. 9, but do not permit any other exceptions. See Leatherman v. Tarrant County Narcotics Intelligence and Coordination Unit, 507 U.S. 163, 168 (1993) (holding that the heightened pleading standard is not permissible in $\$ 1983$ civil rights claims against municipalities, which are not among those that Rule 9 excepts from the general pleading rules).

330. See FED. R. CIV. P. 12(b) (6). See generally Hishon v. King \& Spalding, 467 U.S. 69, 73 (1984) (stating that a motion to dismiss may not be granted unless "it is clear that no relief could be granted under any set of facts that could be proved consistent with the allegations"); Conley v. Gibson, 355 U.S. 41, 45-46 (1957) (explaining that a complaint should not be dismissed unless it appears "that the plaintiff can prove no set of facts in support of his claim").

331. See EdWARD J. BRUNET ET AL., SUMMARYJUdGMENT: FEDERAL LAW AND PRACTICE § 1.01, at 2 (1994) (explaining that the shift to notice pleading resulted from the system's new emphasis on the discovery process and other post-pleading procedures).

332. See id. For a contrary and persuasive argument that the courts have reintroduced higher pleading standards in certain areas of the law, in spite of the relatively lenient pleading standards under the Federal Rules, see Richard L. Marcus, The Revival of Fact Pleading Under the Federal Rules of Civil Procedure, 86 Colum. L. REv. 433, 444-51 (1986).

333. See Marcus, supra note 332, at 484 (citation omitted) (explaining that summary judgment allows a court to determine if claims are supported by enough evidence to go to trial). See generally Celotex Corp. v. Catrett, 477 U.S. 317, 327 (1986) (observing that, with the advent of notice pleading, summary judgment functions as a tool to screen out factually insufficient claims and to prevent them from going to trial). The basic understanding and operation of the summary judgment device has long been the topic of scholarly scrutiny, generating disputes about the purposes of summary judgment, its application and use as a screening device in federal civil litigation, and problems that arise in its administration by trial courts. This section of the Article does not attempt to revisit these disputes, but only to introduce some basic concepts about summary judgment that may be helpful in evaluating its intersection with qualified immunity. The academic literature is rich with insightful discussions of such problems. See, e.g., Richard L. MARCuS et AL.., Civil. Procedure: A MODERn APPROACH 399440 (2d ed. 1995) (discussing nature of summary judgment, concept of burden shifting, and appropriate standards for determining burden of production); William W. Schwarzer et al., The Analysis and Decision of Summany Judgment Motions, 139 F.R.D. 441, 445 (1991) [hereinafter Schwarzer et al., 
Summary judgment, the preferred method for adjudicating qualified immunity claims, is one tool within the arsenal of federal trial judges to screen all types of legal claims at different stages of the litigation process. ${ }^{334}$ As a general rule, summary judgment's purpose "is to discover whether the parties have enough evidence to justify the time and expense of a trial." jectives, such as the preservation of scarce judicial resources, the minimization of litigation expenses, the encouragement of settling claims, and the narrowing of issues to be raised at trial if one is still necessary after the motion is resolved. ${ }^{336}$

For years, however, in the view of many litigators, judges, and commentators, the promise of summary judgment as an effective gatekeeper to federal trials proved elusive. ${ }^{397}$ In its earlier stages, summary judgment was not favored. Trial judges were reluctant to employ summary judgment, particularly in complex cases, partly out of concern for being reversed on appeal. ${ }^{338}$ Others raised concerns about summary judgment's interference with access to the courts and the Seventh Amendment right to a jury trial. ${ }^{339}$ Still others worried that wide availability of summary judgment motions might encourage harassment of parties. ${ }^{340}$ These observers speculated that parties might file unfounded summary judgment motions to drive up the opposing party's litigation costs, to obtain a preview of the party's case, and to gain leverage for favorable settlements. ${ }^{34}$

In addition to these policy considerations, many attributed the difficulty in obtaining summary judgment to the courts' interpretation of Rule $56{ }^{342}$ Under the Federal Rules, a party may obtain summary

Summary Judgment Molions] (explaining Rule 56 and its application); David P. Currie, Thoughts on Direcled Verdicts and Summary Judgments, 45 U. CHI. L. REV. 72, 76-79 (1977) (explaining how to clarify and improve upon the summary judgment device); Martin B. Louis, Federal Summary Judgment Doctrine: A Critical Analysis, 83 YALE L.J. 745, 746 (1974) (isolating "the factors which account for the inadequacy of present summary judgment procedure" in order to encourage modest reform).

334. See BRUNET ET AL., supra note $331, \S 1.01$, at $2-6$ (discussing the availability of procedural devices such as motions to dismiss for failure to state a claim, directed verdicts, judgments notwithstanding the verdict, pretrial orders, and motions in limine).

335. Currie, supra note 333 , at 78.

336. See Schwarzer et al., Summary Judgment Motions, supra note 333, at 451.

337. See id. at 450 ("As Rule 56 approached its fiftieth anniversary, it was encumbered by ambiguities, an overlay of restrictive interpretations, and considerable judicial aversion.").

338. See id.

339. See generally id. at $448,474 \&$ n.184.

340. See id. at 450 .

341. Seeid.

342. See, e.g., Jack H. Friedenthal, Cases on Summay Judgment: Has There Been a Malerial Change in Standards?, 63 NOTRE DAME L. Rkv. 770, 775-76 (1988) (explaining that substantial emphasis was placed on the question of whether the moving party "sufficiently established the non-existence of any material fact" and that this interpretation of Rule 56 limited the use of 
judgment "if the pleadings, depositions, answers to interrogatories, and admissions on file, together with the affidavits [submitted on summary judgment], if any, show that there is no genuine issue as to any material fact and that the moving party is entitled to a judgment as a matter of law." ${ }^{3+3}$ The mechanics of applying this standard have presented a central difficulty with the doctrine.

Two important and much-debated aspects of summary judgment are particularly relevant when examining the intersection of summary judgment and qualified immunity. First, significant dispute has arisen over what procedural burden the moving party must meet to shift the burden of production to the nonmoving party. The law governing this standard has changed significantly since the adoption of the Federal Rules, and is now understood to depend upon which party, the moving party or nonmoving party, bears the ultimate burden of persuasion at trial on the issue for which summary judgment is sought. $^{344}$ A second, and closely related issue, is what quantum of evidence the nonmoving party must produce in order to defeat the summary judgment motion. The answer to that question also depends heavily upon which party bears the burden of persuasion. ${ }^{345}$

Before exploring the burden of persuasion, it is worth identifying the multiple meanings the word "burden" is assigned in the summary judgment context. First, there is the moving party's initial burden in supporting her summary judgment motion. The moving party must meet this initial burden before the nonmoving party is required to respond. While this initial burden is sometimes described as a burden of production, it can actually entail either a traditional production burden or the simple process of pointing out or highlighting the absence of sufficient evidence to support the nonmoving party's case. $^{3: 6}$ This Article characterizes the latter method as a

summary judgment); Sonenshein, supra note 321, at 780 (noting that the "absence of clear guidelines governing the application of Rule $56^{\prime \prime}$ led to the courts' limited use of the summary judgment device).

343. FED. R. CIV. P. 56(c). Similar summary judgment rules are in place in many state court systems, where constitutional tort claims may also be litigated. See, e.g., CAI.. CIV. PROC. CODE $\$$ 437c (West 1973 \& Supp. 1997); 735 IL.L. COMP. STAT. ANN. 5/2-1005 (West 1992 \& Supp. 1997); N.Y. C.P.L.R. 3212 (McKinney 1992 \& Supp. 1997).

344. For an excellent introduction to the relevant burdens in the summary judgment context, see MARCUS ET AL., supra note 333 , at 400-02.

345. See id. (discussing interrelation between burden of persuasion and burden of production within summary judgment).

346. See, e.g., Celotex Corp. v. Catrett, 477 U.S. 317, 329 (1986) (Brennan, J., dissenting) (describing moving party's burden as a burden of production); Linda S. Mullenix, Summary Julgment: Taming the Beast of Burdens, 10 AM. J. TrIAL ADVOC. 433, 462-64 (1987) (same). Professor Louis contended that the moving party could meet its initial burden in one of two ways. First, he suggested that the moving party could review the nonmoving party's evidence and demonstrate that such evidence would not be sufficient to meet the nonmoving party's burden 
"highlighting" burden. Second, there is the nonmoving party's burden of production, the burden to produce evidence responding to the contention that there is no genuine issue of material fact. Finally, the burden of persuasion is the burden to prove to the fact finder, under the relevant standard, that a particular party's version of the facts is true.

\section{A. The Allocation of Burdens When the Nonmoving Party Bears the Burden of Persuasion}

\section{The moving party's initial burdens}

The widely recognized turning point for the summary judgment doctrine was the 1986 trilogy of Supreme Court decisions in Celotex Corp. v. Catrett, ${ }^{347}$ Anderson v. Liberty Lobby, Inc. ${ }^{348}$ and Matsushita Electric Industry v. Zenith Radio Corp. ${ }^{349}$ These cases reflect the Court's desire to enhance judges' use of summary judgment in eliminating claims before trial, and have arguably led to a greater capacity for resolving cases in this manner. ${ }^{350}$

In Celotex, the Court dramatically refined, if not overruled, the moving party's burden as defined by its earlier decision in Adickes $v$. S.H. Kress, ${ }^{351}$ the bête noire of summary judgment advocates. In Adickes, the Court appeared to impose a fairly high burden on parties moving for summary judgment. The case involved a civil rights claim by an anti-segregation protester who violated racial segregation rules by seeking service at a department store lunch counter. ${ }^{352}$ After store

of production at trial on an essential element of the nonmoving party's claim. See Louis, supra note 333, at 750 . This burden is consistent with this Article's characterization of a "highlighting" burden and with the Celotex majority's articulation of the initial burden. See Celotex, 477 U.S. at 325. Second, the moving party could point to its own proof, such as affidavits, to show the nonexistence of an essential element of the nonmoving party's case. See Louis, supra, at 750. This latter burden could be described more fairly as a burden of production.

347. 477 U.S. 317 (1986).

348. 477 U.S. 242 (1986).

349. 475 U.S. 574 (1986).

350. The trilogy has been the subject of substantial scholarly commentary. See, e.g., Schwarzer et al., Summay Judgment Motions, supra note 333, at 450-52; Friedenthal, supra note 342, at 775-87; Samuel Issacharoff \& George Lowenstein, Second Thoughts About Summay Judgment, 100 YALE L.J. 73, 76-94 (1990); John E. Kennedy, Federal Summary Judgment: Reconciling Celotex v. Catrett with Adickes v. Kress and the Evidentiary Problems Under Rule 56, 6 REv. LITIG. 227 (1987); Mullenix, supra note 346, at 449-66; Melissa L. Nelken, One Step Forward, Two Steps Back: Summay Judgment Afler Celotex, 40 HASTINGS L.J. 53 (1988); D. Michael Risinger, Another Step in the Counter-Revolution: A Summary Judgment on the Supreme Courl's New Approach to Summary Judgment, 54 BROOK. L. REV. 35 (1988); Jeffrey W. Stempel, A Dislorted Mirror: The Supreme Court's Shimmering View of Summary Judgment, Directed Verdict, and the Adjudication Process, 49 OHIO ST. L.J. 95, 100-08 (1988).

351. 398 U.S. 144 (1970).

352. See id. at 146 . 
employees refused her service, she left the premises and was arrested by local police for violating local vagrancy laws. ${ }^{353}$ A fundamental element of her $\S 1983$ damages claim was that the police and store owners conspired to deprive her of her equal protection rights. ${ }^{354}$ The government defendants moved for summary judgment on the grounds that the plaintiff had failed to show any evidence of such a conspiracy. ${ }^{355}$

The trial court entered summary judgment for the defendants on the conspiracy claim because the plaintiff had failed to allege any facts from which a conspiracy could be inferred. ${ }^{356}$ After the appellate court affirmed, the Supreme Court reversed, concluding that the defendants had failed to carry their initial burden of "showing the absence of any genuine issue of fact." Court held, the defendants needed to submit evidence, such as affidavits, denying that the police officers were in the store at the relevant time. ${ }^{35 x}$ The Court required this even though, as Professor Currie has noted, "there was no evidence before the Court suggesting a policeman was in the store." 359 Because the plaintiff would have the burden of production and persuasion on the conspiracy issue at trial, a similar motion at the close of plaintiff's evidence would have required a directed verdict for the defendant. ${ }^{360}$ Nonetheless, the Court rejected summary judgment for the Adickes defendants.

The decision turned on the Court's interpretation of what was required to "show" the absence of a material fact within the meaning of Rule 56(c).$^{361}$ Adickes appeared to require that, even in the absence of evidence presented by the nonmoving party, the moving party needed to make an evidentiary showing to prove a negative-that the nonmoving party had not established a fact on which she would have the burden of persuading the fact finder at trial. ${ }^{362}$ Adickes has long been criticized for placing too high a burden on summary judgment

353. See id.

354. See id. at 147.

355. See id. at 153.

356. See id. at 147-48 (citing Adickes v. S.H. Kress, 252 F. Supp. 140, 144 (S.D.N.Y. 1966)).

357. Id. at 153.

358. See id. at 160 .

359. Currie, supra note 333 , at 78 (emphasis added).

360. See Adickes, 398 U.S. at 153 (stating that the district court used this reasoning when it granted summary judgment on the conspiracy issue).

361. Ser id. at 159 (asserting that 1963 amendment to Rule 56(e) was not intended to modify the burden of the moving party under Rule 56(c); see also FED. R. Civ. P. 56(c) (stating that summary judgment will be granted if "the pleadings, depositions, answers to interrogatories, and admissions on file, together with the affidavits, if any, show that there is no genuine issue as to any material fact and that the moving party is entitled to a judgment as a matter of law").

362. See Adickes, 398 U.S. at 160. 
movants who do not bear the burden of persuasion on a trial issue. ${ }^{363}$ One commentator has argued that the result in Adickes undermines the very purpose of Rule 56, which is to discover whether the parties have sufficient evidence to justify the resource consumption necessitated by a trial. ${ }^{364}$ Indeed, "[ $\left.\mathrm{t}\right]$ aken at face value, the Adickes opinion would severely, and unnecessarily cripple the use of summary judgment." 365

On the other hand, other authors have pointed out that permitting the moving party to cavalierly force the nonmoving party to come forward with specific evidence supporting her claim may lead to harassment, even in cases when it is clear that the nonmoving party will be able to demonstrate a genuine factual dispute. ${ }^{366}$ Moreover, the actual process of summary judgment litigation, some have acknowledged, consumes judicial and litigant resources, sometimes without a pretrial resolution. ${ }^{367}$

In Celotex, ${ }^{368}$ the Court responded to these concerns. In that case, a woman who was the administratrix of her husband's estate sued several companies concerning her husband's exposure to asbestos products allegedly manufactured by them. ${ }^{369}$ A year after the suit was filed, Celotex filed a summary judgment motion asserting that the plaintiff failed to produce any evidence that her husband had been exposed to asbestos it had manufactured. ${ }^{370}$ Celotex argued that the plaintiff had failed to identify any witnesses who could testify about the decedent's exposure to its asbestos products. ${ }^{371}$ In her response, the plaintiff submitted three documents that she argued supported her claim that her late husband had been exposed to Celotexmanufactured asbestos in Chicago during 1970-71: (1) a transcript of the decedent's deposition; (2) a letter from one of decedent's former employers whom the plaintiff intended to call as a trial witness; and (3) a letter from an insurance company to plaintiff's attorney. ${ }^{372} \mathrm{Ce}-$

363. See, e.g., Currie, supra note 333 , at 76.

364. See id.

365. Friedenthal, supra note 342 , at 779 . From an alternative, Realist perspective, Dean Friedenthal has argued that Adickes "can be explained in that it was an important civil rights case that the Court did not want to dispose of without trial. The discussion of summary judgment was simply a means of masking a difficult substantive issue." Id.

366. See idl. at 776-77; Louis, supra note 333 , at 753-60.

367. See BRUNET ET AL., supra note 331, § 3.02; William W. Schwarzer, Summary Judgment Un. der the Federal Rules: Defining Genuine Issues of Material Fact, 99 F.R.D. 465, 483 (1983) [hereinafter Schwarzer, Summay Judgment Under the Federal Rules].

368. 477 U.S. 317 (1986).

369. See id. at 319.

370. Sep id. at 319-20.

371. See id. at 320.

372. See id. 
lotex argued that none of the three established a genuine issue of fact because they were all inadmissible hearsay, and therefore could not be considered on summary judgment. ${ }^{373}$

The trial court agreed with Celotex, but the court of appeals reversed, relying on the language of Rule $56(\mathrm{e})^{374}$ and on Adickes ${ }^{375}$ to find that Celotex had not met its initial burden of establishing with any evidence that the decedent had not been exposed to its products. ${ }^{376}$ On appeal, the Supreme Court reversed. ${ }^{377}$ It held that, assuming adequate time for discovery has passed and a motion has been made, Rule 56(c) required summary judgment to be entered "against a party who fails to make a showing sufficient to establish the existence of an element essential to that party's case, and on which that party will bear the burden of proof at trial." ${ }^{378}$ The majority clarified this proposition by stating that, while the moving party bears the burden of "informing" the trial court of the basis for its motion, it need not support its motion with affidavits or other evidentiary materials negating the nonmoving party's claim. ${ }^{379}$ This is what I have referred to as the "highlighting" burden. ${ }^{380}$ Indeed, the Court observed, the language of Rule 56 itself suggests that the drafters contemplated that not all summary judgment motions would be supported by evidentiary matter. ${ }^{381}$ The Court indicated that in cases when the nonmoving party will bear the burden of persuasion on a dispositive issue at trial, summary judgment may be based "solely on the 'pleadings, depositions, answers to interrogatories, and admissions on file." "**z

373. See id.

374. Rule 56(e) states, in part, that

[w] hen a motion for summary judgment is made and supported as provided in this rule, an adverse party may not rest upon the mere allegations or denials of his pleading, but his response, by affidavits or as otherwise provided in this rule, must set forth specific facts showing that there is a genuine issue for trial.

FED. R. CIV. P. 56(e).

375. Adickes read Rule 56(e) to shift the burden of production to the nonmoving party oniy after the moving party has adequately supported her motion with evidentiary matter. See Adickes v. S.H. Kress \& Co., 398 U.S. 144, 159-60 (1970) (citing Advisory Committee Note on 1963 Amendment to FED. R. CIV. P. 56(e)).

376. See Catrett v. Johns-Manville Sales Corp., 756 F.2d 181, $184 \&$ n.10 (D.C. Cir. 1985), rev'd sub nom. Celotex Corp. v. Catrett, 477 U.S. 317 (1986).

377. See Celolex, 477 U.S. at 319.

378. Id. at 322.

379. See id. at 323.

380. See supra note 346 and accompanying text.

381. See Celotex, 477 U.S. at 323 (noting that Rule 56(c) refers to "'the affidavits, if any," and that Rules 56(a) and (b) provide that moving parties may move for summary judgment "with or without supporting affidavits"' (quoting FED. R. Civ. P. 56(a)-(c))).

382. Id. at 324 (quoting FED. R. CIV. P. 56(e)). 
In response to the appellate court's reliance on Adickes, ${ }^{383}$ the Court in Celotex concluded that Adickes did not stand for the proposition that the moving party was required to submit evidence to show the absence of a genuine factual issue. ${ }^{384}$ In explaining this, the Court stated that Adickes should not

be construed to mean that the burden is on the party moving for summary judgment to produce evidence showing the absence of a genuine issue of material fact, even with respect to an issue on which the nonmoving party bears the burden of proof. Instead, as we have explained, the burden on the moving party may be discharged by "showing"-that is, pointing out to the district court-that there is an absence of evidence to support the nonmoving party's case. $^{385}$

In other words, to meet her initial burden, the moving party need only comprehensively evaluate the record produced on discovery and highlight the absence of facts supporting the nonmoving party's legal claim. The Court concluded that Celotex met its initial burden, but remanded the case to the lower court to evaluate whether the plaintiff had met her responsive burden of establishing a genuine issue of fact by showing that she had sufficient evidence of the decedent's exposure to Celotex-manufactured asbestos to justify a trial. ${ }^{386}$

In clarifying the duty of the moving party to discharge its initial burden under summary judgment rules, the Court unequivocally endorsed the employment of summary judgment as a procedure to isolate factually insufficient claims or defenses and prevent them from going to trial. ${ }^{387}$ The Court noted that as long as trial courts ensure adequate opportunities for discovery, expanded use of the summary judgment motion will not result in unfair and premature resolution of nonmoving parties' claims. ${ }^{388}$ Celotex has been widely interpreted to have substantially altered the existing standard for evaluating the moving party's initial burden on summary judgment, notwithstanding the fact that it did not formally overrule Adickes. ${ }^{389}$ Although

383. See Adickes v. S.H. Kress \& Co., 398 U.S. 144 (1970).

384. See Celotex, 477 U.S. at 325.

385. Id. (emphasis added).

386. See id. at 326-27. In doing so, however, the Court indicated that the nonmoving party does not necessarily need to meet its burden with evidence "in a form that would be admissible at trial." Id. at 324. Thus, the hearsay nature of the plaintiff's evidence would not necessarily preclude her from defeating Celotex's motion. See id.

387. See id. at 327.

388. See id. at 326.

389. See id. at 334 (Brennan, J., dissenting) (agreeing with the majority's general approach to burden shifting and with its contention that Adickes and Celotex are not inconsistent); see also BRUNET ET AL., supra note $331, \S 2.06$ (noting that the Court in Celolex substantially altered the approach to burden shifting under summary judgment "without admitting that it was doing 
there has been some dispute about the scope of the Court's holding, commentators have agreed that the decision signaled the Court's endorsement of the widespread employment of summary judgment to limit trials in the federal judicial system. ${ }^{390}$ By carefully defining the moving party's burdens on summary judgment, Celotex is highly relevant to the adjudication of public officials' claims of qualified immunity.

\section{The nonmoving party's burden of production and the quantum of evidence necessary to meet the burden}

Under Adickes and Celotex, once a moving party has met her initial burden (her highlighting burden or production burden), the burden of production shifts to the nonmoving party, who must respond with sufficient evidence such that a reasonable fact finder could find for her at trial. ${ }^{391}$ The deference accorded to nonmoving parties with regard to satisfying this responsive burden is another perceived limitation to the utility of traditional summary judgment doctrine. First, it is widely understood that on summary judgment the evidence must be viewed "in the light most favorable to the party opposing the motion." 992 Second, federal courts have, to some degree, relied on the so-called "slightest doubt" standard derived from the oft-cited case of Arnstein v. Porter. ${ }^{393}$ Under the slightest doubt standard, even if the nonmoving party has not presented evidence to rebut the summary judgment motion, summary judgment may not be granted if there is the slightest doubt that a genuine issue of material fact exists. ${ }^{394} \mathrm{Al}-$ though courts have recently abandoned, or at least limited, the slightest doubt standard, ${ }^{395}$ that standard has long symbolized the frustration of those who value summary judgment as an effective gatekeeping device. ${ }^{396}$

In the two other cases that comprise the summary judgment tril-

so"); Kennedy, supra note 350, at 246-48 (arguing that Adickes and Celotex can be reconciled by alternative interpretations of the Court's reasoning). But see BRUNET ET AL., supra, $\$ 2.06$ n.66 (characterizing Professor Kennedy's attempt to reconcile the two cases as "largely unsuccessful" $\left.{ }^{n}\right)$.

390. See, e.g., Friedenthal, supra note 342, at 776; Nelken, supra note 350, at 75 n.106.

391. See Celolex, 477 U.S. at 324; Adickes v. S.H. Kress \& Co., 398 U.S. 144, 160-61 (1970). If the moving party fails even to meet her initial burden, the motion should be dismissed whether or not the nonmoving party responds. See id.; Louis, supra note 333, at 750.

392. United States v. Diebold, Inc., 369 U.S. 654, 655 (1962), ciled inAdickes, 398 U.S. at 15859.

393. 154 F.2d 464 (2d Cir. 1946).

394. See id. at 468.

395. See BRUNET ET AL., supra note $331, \S 3.03$, at 73-74 (discussing cases that reject or limit the "slightest doubt" standard).

396. See, e.g., Stempel, supra note 350 , at 107. 
ogy, Anderson v. Liberty Lobby, Inc. ${ }^{397}$ and Matsushita Electric Industrial Co. v. Zenith Radio Corp., ${ }^{398}$ the Court made it more difficult for a nonmoving party with the burden of persuasion to meet its burden of production on summary judgment. In Liberty Lobby, a publisher and author moved for summary judgment on a libel suit brought against them by a non-profit organization. ${ }^{399}$ In Matsushita, the defendants in a civil antitrust case moved for summary judgment against the plaintiffs, who had alleged that the defendants had engaged in a predatory pricing conspiracy. ${ }^{400}$

These cases clarified the burdens that nonmoving parties must meet in order to defeat a summary judgment motion, assuming that these parties will bear the burden of persuasion at trial. In Liberty Lobby, the Court rejected the notion that the nonmoving party could meet its burden simply by showing the mere existence of "some" factual dispute between the parties. ${ }^{401}$ Rather, the nonmoving party must identify a factual dispute that is genuine and involves a material issue. ${ }^{402}$ Material facts are those that could affect the outcome of the suit; materiality, therefore, is a function of the underlying substantive law, rather than of summary judgment law. ${ }^{403}$

The Court also underscored the fact that not all evidentiary conflicts constitute "genuine" disputes of fact. ${ }^{404}$ Nonmoving parties can establish a genuine issue of fact by producing evidence that is sufficient such that a reasonable jury could return a verdict for the nonmoving party. ${ }^{405}$ Thus, for the first time, the Court equated the test for determining whether a genuine factual dispute exists with the test for granting a directed verdict at trial. ${ }^{406}$ Closely related to this characterization was the Court's conclusion that this issue must be assessed in light of the evidentiary burden established by the substantive law. ${ }^{407}$ Thus, in an ordinary civil case, the judge must ask whether a fair-minded, reasonable jury could find that the plaintiff has proven

\footnotetext{
397. 477 U.S. 242 (1986).

398. 475 U.S. 574 (1986).

399. See Liberly Lobby, 477 U.S. at 245.

400. See Malsushita, 475 U.S. at 577-78.

401. See Liberly Lobby, 477 U.S. at $247-48$.

402. See id. at 248.

403. See id.

404. See id.

405. See id.
}

406. See id. at 251 ; see also Currie, supra note 333, at 79 ("The purpose of rule 56 requires that summary judgment be granted if and only if the evidence before the court would justify a directed verdict if presented at trial.") (footnote omitted). These procedural devices are now known as motions for judgment as a matter of law. See FED. R. CIV. P. 50.

407. See Liberty Lobby, 477 U.S. at 248. 
her case by a preponderance of the evidence. ${ }^{408}$ The Court maintained that this procedure did not supplant the role of the jury. ${ }^{409}$ It warned, for example, that it would be inappropriate for the trial court to make credibility determinations, weigh the evidence, or draw legitimate inferences from the facts in a summary judgment proceeding. ${ }^{410}$

Finally, in both Liberty Lobby and Matsushita, the Court rejected any idea that the "slightest doubt" standard retains any viability in modern procedure law." In Liberty Lobby, for instance, the Court stated that " $[t]$ he mere existence of a scintilla of evidence in support of the plaintiff's position will be insufficient ...."112 Similarly, in Matsushita, the Court stated that in order to establish a genuine issue for trial, the nonmoving party "must do more than simply show that there is some metaphysical doubt as to the material facts."

Even in light of these new standards, however, it should be noted

408. See id. at 252. A major issue in Liberty Lobby was whether trial courts were obligated to take into account heightened evidentiary burdens in applying this standard. The Court held that the judge must incorporate the proof standard in evaluating whether summary judgment is appropriate. See id. at 252-54. Accordingly, in a public figure defamation case, the judge must decide whether the evidence presented by the nonmoving party would allow a reasonable jury to conclude that there was clear and convincing evidence of actual malice. See id. at 254. In assessing the existence of a genuine issue of material fact, the Court instructed the trial judge to "bear in mind the actual quantum and quality of proof necessary to support liability." Id. Thus, according to the majority, if the nonmoving party's affidavits present evidence that is of insufficient caliber or quantity to allow a rational finder of fact to find actual malice by clear and convincing evidence," there can be no genuine issue of fact. See id. The dissents criticized this approach. See id. at 266 (Brennan, J., dissenting) (arguing against the majority's suggestion that trial courts must assess and weigh evidence in order to fulfill the Court's mandate, as that is not the traditional province of trial judges on summary judgment); id. at 273 (Rehnquist, J., dissenting) ( $"[T]$ he Court has created a standard that is different from the standard traditionally applied in summary judgment motions without even hinting as to how its new standard will be applied to particular cases." ${ }^{n}$ ). The relevance of this aspect of the Liberty Lobby opinion to qualified immunity remains to be seen. See generally Crawford-El v. Britton, 93 F.3d 813, 815 (D.C. Cir. 1996) (en banc) (holding that in constitutional tort cases where defendant is a government official who asserts qualified immunity, and where state of mind is an element of plaintiff's claim, plaintiff must prove her case by clear and convincing evidence), cert. granted, 117 S. Ct. 2451 (1997).

409. See Lilerty Lobly, 477 U.S. at 252.

410. See id. at 255. The Court's Liberly Lobby opinion has generated a great deal of academic commentary and perhaps even more confusion in its application. Although Liberly Lobly's impact could have been limited because of the unusual nature of First Amendment/defamation law, several commentators have characterized the Court's opinion as a watershed for summary judgment advocates. See, e.g., BRUNET ET AL., supra note 331, \$§ 3.04, 3.06 (arguing that $l$ iberly Lobly and Malsushila have substantially increased judicial receptiveness to summary judgment); Issacharoff \& Lowenstein, supra note 350 , at 75 (contending that the Court's summary judgment trilogy may have adversely affected the ability of parties to settle cases and fundamentally altered the balance of power between litigants by raising the costs and risks to plaintiffs while decreasing the same for defendants).

411. See BRUNET ET AL., supra note 331, $\$ 3.04$ (contending that the Supreme Court's discussion of "metaphysical doubt" effectively repudiated the slightest doubt standard).

412. Liberly Lobby, 477 U.S. at 252.

413. Malsushila, 475 U.S. at 586 (citations omitted). 
that a nonmoving party in an ordinary case may delay having to meet her burden of production if she successfully contends pursuant to Rule 56(f) that she cannot present facts essential to oppose the motion. ${ }^{414}$ The trial court may then either deny the summary judgment motion or continue it until further discovery can be conducted. ${ }^{415}$ This rule may have significant implications for plaintiffs responding to summary judgment on qualified immunity claims. ${ }^{416}$

\section{B. The Allocation of Burdens When the Moving Party Bears the Burden of Persuasion}

When the moving party would bear the burden of persuasion on the trial issue to be adjudicated on summary judgment, the Court has established quite different standards. Here, the stakes are different, as the moving party must establish a strong enough case to justify finding in its favor without a trial and denying the nonmoving party her opportunity to put on a defense. The treatment of this issue in judicial decisions and academic literature is much less extensive than the previous issues, perhaps because summary judgment motions are more commonly filed by parties who do not bear the burden of persuasion. ${ }^{47}$

The clearest statement about the standards for granting summary judgment to a party who bears the burden of persuasion is in Justice Brennan's Celotex dissent. In clarifying the structure of summary judgment adjudication, Justice Brennan wrote:

If the moving party will bear the burden of persuasion at trial, that party must support its motion with credible evidence-using any of the materials specified in Rule 56(c) - that would entitle it to a directed verdict if not controverted at trial. Such an affirmative showing shifts the burden of production to the party opposing the motion and requires that party either to produce evidentiary materials that demonstrate the existence of a "genuine issue" for trial or to submit an affidavit requesting additional time for discovery.

414. See FED. R. Civ. P. 56(f) (stating that a court "may refuse the application for judgment or may order a continuance to permit affidavits to be obtained or depositions to be taken or discovery to be had or may make such other order as is just").

415. See id.

416. See infra note 538 and accompanying text.

417. See JACK H. Frifdenthal ET AL., Civil Procedure 445-46 (2d ed. 1993) (observing that in most summary judgment cases it is the nonmoving party who bears burden of persuasion at trial); see also William P. McLauchlan, An Empirical Sludy of the Federal Summay Judgment Rule, 6 J. LEGAL STUD. 427, 441 (1977) (asserting that summary judgment is a device used primarily by defendants); infra note 426 and accompanying text (discussing the fact that defendants may bear the burden of persuasion if the issue on which they seek summary judgment is an affirmative defense).

418. Celotex Corp. v. Catrett, 477 U.S. 317, 331 (1986) (Brennan, J., dissenting) (internal 
The directed verdict standard, in turn, raises a significant barrier for the party with the burden of persuasion. "The party seeking a directed verdict must make a stronger showing of evidence if he bears the burden of persuasion." 19 That party must meet a "strict" standard, showing "through "testimony that the jury is not at liberty to disbelieve" ferences' in a light most favorable to [the nonmoving party], [the evidence] nonetheless 'could lead reasonable men to but one conclusion'-in his favor." ${ }^{421}$ Likewise, on summary judgment, the moving party's case must be so substantial that, on all essential elements of her claim, no reasonable jury could find for the nonmoving party, even after considering the latter's responsive materials. ${ }^{422}$

This is, and should be, a difficult standard to meet at the summary judgment stage. The nonmoving party may have many ways to defeat the moving party's case at trial. For example, the nonmoving party might simply try to challenge the credibility of the moving party's trial witnesses through cross-examination. ${ }^{423}$ Notwithstanding that legitimate trial strategy, a nonmoving party cannot defeat the motion simply by stating her intention to challenge the credibility of the moving party's witnesses. ${ }^{424}$ The nonmoving party needs to provide at least some evidence to support its claim on the merits or to establish

citations omitted); see also Winnacunnet Coop. Sch. Dist. v. National Union Fire Ins. Co., 84 F.3d 32, 35 (1st Cir. 1996) (holding that under Celotex standard, where party that bears burden of proof moves for summary judgment and meets its initial burden, nonmoving party must respond with evidence or seek additional time for discovery); National State Bank v. Federal Reserve Bank, 979 F.2d 1579, 1581-82 (3d Cir. 1992) (same). See generally Schwarzer et al., Summary Judgment Motions, supra note 333 , at $477-78$, which states:

When the moving party bears the burden of persuasion on the issue at trial, its showing must sustain that burden as well as demonstrate the absence of a genuine dispute. Thus, it must satisfy both the initial burden of production on the summary judgment motion-by showing that no genuine dispute exists as to any material fact-and the ultimate burden of persuasion on the claim by showing that it would be entitled to a directed verdict at trial.

Id. (footnotes omitted).

419. California Computer Prods., Inc. v. International Bus. Machs. Corp., 613 F.2d 727, 733 n.2 (9th Cir. 1979) (citing United Cal. Bank v. THC Fin. Corp., 557 F.2d 1351, 1356 (9th Cir. 1977)); see Juhnke v. EIG Corp., 444 F.2d 1323, 1325 (9th Cir. 1971) (holding that a directed verdict for party with burden of proof could be granted only if the court could determine there is only one possible interpretation of evidence, and that interpretation favors the moving party).

420. Jordan v. United States Lines, Inc., 738 F.2d 48, 49 (1st Cir. 1984) (quoting Service Auto Supply Co. v. Harte \& Co., 533 F.2d 23, 25 (1st Cir. 1976)).

421. Id. (quoting Curreri v. Local 251, International Bhd. of Teamsters, 722 F.2d 6, 8 (1st Cir. 1983) (citations omitted)).

422. See Fitzpatrick v. City of Atlanta, 2 F.3d 1112, 1115 (11th Gir. 1993) (citing United States v. Four Parcels of Real Property, 941 F.2d 1428, 1437 (11th Cir. 1991) (en banc)).

423. See Friedenthal ET AL., supra note 417, § 9.3, at 447; see also Fleming JAMES, JR. et AL., CIVII. PROCEDURE $\S 7.15$, at 341 (4th ed. 1992) (noting that testimony usually raises credibility questions).

424. See FrIEDENTHAL. ET AL., supra note $417, \$ 9.03$, at 446-47. 
a reason for doubting the credibility of the moving party's potential witnesses. ${ }^{425}$ While the summary judgment burdens of parties with the burden of persuasion at trial are ordinarily a concern for plaintiffs, these procedural burdens would also be relevant, of course, to a party moving for summary judgment on the basis of a defense on which she would bear the burden of persuasion. ${ }^{426}$

A central aspect of understanding the operation of qualified immunity is how these universal summary judgment standards, including the allocation of procedural, evidentiary, and proof burdens, apply to the resolution of qualified immunity claims. ${ }^{427}$ As the next section discusses, the intersection of qualified immunity and summary judgment generates unanticipated complexities that have plagued the lower courts as they regularly administer and apply the doctrine to public officials' immunity claims.

\section{UNDERSTANDING THE DOCTRINAL CONSEQUENCES OF QUALIFIED IMMUNITY'S FACTUAL NATURE}

The adjudication of qualified immunity presents the confluence of qualified immunity and summary judgment, two doctrines designed to screen claims prior to trial. While one would intuitively think that these two gatekeepers would work well together based on their common underlying goals, the following discussion illustrates that their intersection actually creates substantial doctrinal obstacles to the resolution of constitutional tort claims-or at least it should if courts are properly implementing the two doctrines.

The complexities of evaluating the qualified immunity defense under traditional summary judgment law have not gone entirely unnoticed. Some commentators have attempted to reconcile the two doctrines and assist courts and other scholars to gain a greater understanding of the law. ${ }^{428}$ These attempts, however, have been largely unsuccessful because the two doctrines cannot be harmonized satisfactorily without substantially altering the meaning and purpose

425. See id.

426. See Stutz Motor Car of Am., Inc. v. Reebok Int'l, Ltd., 909 F. Supp. 1353, 1358 (C.D. Cal. 1995), affd, 1997 U.S. App. LEXIS 11877 (Fed. Cir. May 16, 1997).

427. See BRUNET ET AL.., supra note $331, \S 6.10$ (investigating qualified immunity defense and its relationship to summary judgment).

428. See id. (noting special problems associated with application of summary judgment to qualified immunity defense); see also MARCUS ET AL., supra note 333, at 435-36 (examining the two doctrines); Ignall, supra note 263, at 201 (outlining problems with using summary judgment motion to raise qualified immunity defense); Mary A. McKenzie, Note, The Doctrine of Qualified Immunity in Section 1983 Actions: Resolution of the Immunily Issue on Summary Judgment, 25 SUFFOLK U. L. REV. 673, 699-700 (1991) (examining whether qualified immunity defense can be decided as a matter of law). 
of one or the other. Summary judgment, which is designed to eliminate unnecessary trials, operates quite differently from qualified immunity, which is designed to protect officials from all pre-trial litigation processes, including summary judgment. Thus, the Court's articulation of the immunity doctrine to include an inherent, or at least predominant, factual component has greatly complicated both the law of qualified immunity and the law of summary judgment. As this section explains, proper consideration of this factual component is essential to understanding and explaining the substantial conceptual confusion surrounding the doctrine's application. ${ }^{429}$ It might also provide a foundation for reforming qualified immunity.

The principal, but surprisingly unrecognized, doctrinal consequence of the Court's current approach is that the factual aspect has made qualified immunity conceptually irreconcilable with traditional summary judgment doctrine. The Supreme Court has assumed that summary judgment is an effective device for adjudicating qualified immunity claims because it insists that qualified immunity is a question of law. ${ }^{430}$ It seems intuitive that summary judgment could properly serve the function envisioned by the Court, because it is a procedural device designed to facilitate summary resolution of legal claims where there is no genuine issue of material fact and the parties are unlikely to generate one even if they went to trial. Moreover, the two doctrines have compatible objectives; both are consciously designed to filter legal claims at some point prior to trial.

Due to the significance of factual questions, however, their confluence has generated doctrinal and conceptual confusion that has manifested itself in three ways. First, qualified immunity's factual component may explain a great deal about the difficulty the Supreme Court has had articulating the precise standard to be applied to qualified immunity claims raised on summary judgment. ${ }^{431}$ Second, factual complexities have provoked the lower federal courts to substantially alter or modify the detailed burdens under summary judgment in manners that conflict with the Court's summary judgment trilogy. Finally, the factual analysis embedded into qualified immunity doctrine explains why the courts have never been able to sort out a critical, but unresolved, question-which party bears the

429. See, e.g., Flatford v. City of Monroe, 17 F.3d 162, 166 (6th Cir. 1994) ("[T]he difficulty for all judges with qualified immunity has not been articulation of the rule, but rather the application of it.").

430. See Harlow v. Fitzgerald, 457 U.S. 800,818 (1982).

431. See Hunter v. Bryant, 502 U.S. 224, 235 (1991) (Kennedy, J., dissenting) (indicating substantial disagreement among Supreme Court Justices about the proper summary judgment standards to be applied to qualified immunity claims). 
burden of persuasion on the qualified immunity defense. Until this last question is answered, if indeed it can be, the courts will be unable to appropriately articulate the summary judgment standards necessary to provide guidance to parties, trial courts, and scholars who wish to better understand this area of the law.

\section{A. Ascertaining the Elusive Summary Judgment Standard for "Qualified" Immunity}

Three recurring and related issues under the qualified immunity doctrine are the articulation of the proper summary judgment standard to be applied, the scope of discovery permissible, and the role, if any, of juries. The capacity for significant disputes about the factual basis of an immunity defense creates difficult conceptual issues in each of these areas.

Much of the confusion relates to the hybrid nature of a "qualified" immunity. Immunities can serve three independent functions. First, an immunity may protect defendants from the burdens of extensive pretrial discovery and motions practice ("pretrial litigation immunity"). Second, even if the defendants must undergo discovery and pretrial motions practice, immunity may still protect defendants from trial ("trial immunity"). Finally, an immunity may operate as a barrier to liability, even in cases where a defendant must undergo discovery, pretrial proceedings, and a trial ("liability immunity").

In order to facilitate the distinct protection each of these immunities offers, a different procedural device is necessary. Pretrial litigation immunity can generally be protected by procedural mechanisms that permit certain types of claims to be screened out on the pleadings. The goal of trial immunity can be accomplished by devices for adjudicating claims short of trial, such as summary judgment. Finally, liability immunity can be protected by substantive defenses that can be asserted at trial, and which may add a layer of protection from liability, if not from the burdens of litigation.

\begin{tabular}{|l|l|}
\hline IMMUNITY TYPE & PROCEDURAL VEHICLE \\
\hline $\begin{array}{l}\text { From Pretrial Litigation } \\
\text { (Suit) }\end{array}$ & Pleading Motions \\
\hline From Trial & Summary Judgment Motion \\
\hline From Liability & Substantive Defense \\
\hline
\end{tabular}

Since its inception, the qualified immunity doctrine has defied classification along these lines, partly because the Court has created a 
hybrid of this simplified model. The Court's immunity decisions have variously characterized qualified immunity as a liability immunity, a trial immunity, and a pretrial litigation immunity (or immunity from suit). This hybridization, in turn, has confused understanding about the proper legal standards under the qualified immunity doctrine.

The confusion began in Harlow $v$. Fitzgerald, ${ }^{432}$ when the Court set out procedural guidelines for administering the defense. In describing how qualified immunity claims should be resolved, the majority sent out mixed signals. Initially, the Court indicated that trial court judges should first examine whether the defendant's conduct, as alleged by the plaintiff, violated clearly established constitutional rights. ${ }^{433}$ This ruling reflects the Court's understanding that trial courts could evaluate the merits of a qualified immunity defense on the pleadings, rather than after development of the factual record. Indeed, the Court originally insisted that no discovery take place until the immunity claim was resolved, further revealing its belief that qualified immunity was a device to screen out claims on the pleadings. ${ }^{434}$ At the same time, however, the Court conveyed a conflicting message by indicating that the preferred procedural device for adjudicating qualified immunity was summary judgment. ${ }^{435}$

Similarly, in Anderson $v$. Creighton, ${ }^{436}$ the Court acknowledged that the initial evaluation of the defense must take place on the pleadings. ${ }^{437}$ The majority indicated that trial courts should first evaluate whether the defendant's conduct, as alleged, violated a clearly established constitutional right. ${ }^{438}$ Consistent with this understanding, Justice Stevens's dissent observed that the relevant focus under Harlow for evaluating whether a right was clearly established is "the rule on which the plaintiff relies." ${ }^{\text {a39 }}$ In other words, both opinions appear to recognize that the proper administration of Harlow was dependent upon it being understood as a pleading rule. Nonetheless, the majority again emphasized that summary judgment was the proper procedural vehicle for resolving qualified immunity claims, and even

432. 457 U.S. 800 (1982).

433. Ser id. at 818.

434. Ser id.

435. Ser id.

436. 483 U.S. 635 (1987).

437. See id. at 646 n.6.

438. See id.

439. Id . at 657-58 (Stevens, J., dissenting) (emphasis added). Justice Stevens made this point in the context of arguing that summary judgment on Anderson's qualified immunity claim was inappropriate and required the development of additional facts. See id. 
softened Harlow by recognizing that if factual disputes surrounding the plaintiff's allegations arose, discovery might be necessary. ${ }^{40}$

Once the Anderson Court acknowledged that discovery might be necessary to sort through a qualified immunity defense, it substantially undermined the idea that qualified immunity might be an effective device for screening constitutional tort claims in order to protect officials from the typical burdens of pretrial litigation, such as discovery. Indeed, the Third Circuit recently observed that Anderson's articulation of the qualified immunity standard was "[i]n strong tension" with the idea of resolving qualified immunity claims as early in the case as possible. ${ }^{41}$ Moreover, as discussed above, it will be difficult for courts to assess the clearly established law standard in light of the pleadings because of the inherently factual nature of the immunity "reasonableness" test, as well as the increasingly factual nature of substantive constitutional law under the now-predominant balancing regime. If the qualified immunity claim reaches the discovery stage, as authorized by Anderson, disputes over historical facts, or perhaps over the inferences to be drawn from those facts, are highly likely to arise.

Thus, so long as it remains "qualified," or fact dependent, immunity can never be entirely successful (and perhaps not successful at all) in acting as a barrier to trial or pretrial discovery. Only an absolute immunity, less susceptible to extensive factual nuances, can operate as a trial and pretrial litigation immunity with any measurable success. $^{442}$ Indeed, much of the reasoning the Court uses to justify early termination in its qualified immunity analysis is drawn from its absolute immunity cases, even though the two doctrines operate quite differently. For example, in Tenney $v$. Brandhove, ${ }^{443}$ the Court

440. See id. at 646 n.6. The Court cautioned, however, that discovery should be limited in scope to the specific question of entitlement to immunity. See id.

441. See Grant v. City of Pittsburgh, 98 F.3d 116, 122 (3d Cir. 1996). That is not to say, however, that summary judgment cannot be an effective device for eliminating some pretrial litigation burdens. If summary judgment is available on a relatively expedited basis with narrowly circumscribed discovery, it could partially accomplish the objectives of qualified immunity by limiting, rather than eliminating, pretrial litigation burdens. The extent to which this is true in actual constitutional tort litigation is unknown.

442. That is not to say that factual conflicts that preclude early termination of suits under the absolute immunity doctrine never occur. For example, under current law, whether a prosecutor is entitled to absolute immunity depends upon whether she was performing a "prosecutorial" or "investigative" function, a distinction that may well be fact-dependent. See Buckley v. Fitzsimmons, 509 U.S. 259, 273 (1993) (explaining that determining which role a prosecutor has played depends on the facts of each case). As a practical matter, however, the courts have been better able to evaluate absolute immunity claims on the pleadings. See Imbler v. Pachtman, 424 U.S. 409, 419 n.13 (1976) (asserting that absolute immunity may overcome a suit in its initial stages when the official's actions are within the boundaries of immunity).

443. 341 U.S. 367 (1951). 
declared state legislators absolutely immune from constitutional tort liability. ${ }^{44}$ In Tenney, the Court emphasized the importance of resolving immunity claims at the outset of a case. ${ }^{445}$ Immunity, the Court observed, "would be of little value if [legislators] could be subjected to the cost and inconvenience and distractions of a trial upon a conclusion of the pleader." ${ }^{446}$ Similarly, in Barr $v$. Matteo, ${ }^{47}$ which held that certain federal officials were immune from defamation actions, Justice Harlan's plurality opinion stressed the Court's concern that official immunity should prevent lawsuits, which "consume time and energies which would otherwise be devoted to governmental service."

The problem with the Court's extension of policy reasoning from those decisions to the qualified immunity doctrine is that the goal of eliminating pretrial burdens can be effectively advanced only with an absolute immunity; absolute immunity claims, after all, are susceptible in many cases to resolution based on the pleadings. ${ }^{499}$ Thus, the barriers to early termination of qualified immunity claims, customarily associated with the now-abandoned "subjective" prong of the inquiry and more recently with the assertion of qualified immunity claims when the underlying constitutional violation embodies a state of mind requirement, are actually associated with the "qualified" nature of the immunity doctrine itself. Harlow's transformation of a fact-based qualified immunity into a trial and pretrial litigation immunity was like fitting a square peg into a round hole.

This explains in large measure the difficulty the courts have had in defining the appropriate standard for resolving qualified immunity claims on summary judgment, in sorting out the extent to which discovery should be permitted on qualified immunity claims, and in de-

444. See id. at 379.

445. See id. at 377 .

446. Idl; see also Butz v. Economou, 438 U.S. 478, 522 (1978) (Rehnquist, J., dissenting) (arguing that without absolute immunity, mere allegation of unconstitutional conduct will lead to litigation burdens that immunity seeks to relieve).

447. 360 U.S. 564 (1959) (plurality opinion).

448. Id at 571 .

449. Although this author has called for more rule-like approaches to immunity law, I do not advocate complete conversion of qualified immunity into absolute immunity for all public officials. See Chen, supra note 14, at 346 . Rather, I have argued for a reassessment of immunity in more categorical terms such that some officials or some official functions would be protected by absolute immunity and all other officials would have to defend constitutional tort claims on the merits. See id. Moreover, I have maintained, as have others, that any expansion of absolute immunity categories be coupled with a reexamination of expanding governmental liability. See id. at 338 \& nn.360-62 (referencing SCHUCK, supra note 37, at 100; Schuck, supra note 92, at 346-51; Stephen J. Shapiro, Public Officials' Qualified Immunity in Section 1983 Actions Under Harlow v. Fitzgerald and lis Progeny: A Crilical Analysis, 22 U. MICH. J.L. REFORM 249, 27679 (1989); John D. Kirby, Note, Qualified Immunity for Civil Rights Violations: Refining the Standard, 75 CORNELL. L. REV. 462, 485-88 (1990)). 
ciding what role, if any, juries may play in the evaluation of qualified immunity. As a formal matter, none of these procedural problems should arise if qualified immunity operated as an effective device to protect officials not only from liability, but also from the burdens of trial and pretrial litigation. Complications in these areas occur, however, once it is recognized that qualified immunity claims cannot be evaluated without reference to some set of facts.

For example, the courts' confusion about the scope of available discovery on the immunity claim itself reflects the hybrid nature of qualified immunity. Once the Supreme Court acknowledged in $A n$ derson that discovery would be necessary to adjudicate some qualified immunity claims, it laid the groundwork for substantial confusion among the lower courts. ${ }^{450}$ Discovery, after all, is the most significant pretrial litigation burden that the qualified immunity defense was designed to avoid.

Even when courts acknowledge that evaluation of facts is necessary to decide the qualified immunity issue, however, they generally attempt to isolate the factual issues in a manner that suggests that qualified immunity can effectively protect officials from substantial pretrial litigation. ${ }^{451}$ It has been suggested, for example, that the goals of qualified immunity can be achieved even when discovery is permitted if trial courts carefully limit discovery only to issues necessary to the adjudication of the immunity question. ${ }^{452}$ It is unclear how discovery could be meaningfully limited, however, because the substantive constitutional law inquiry and the qualified immunity inquiry are intertwined. The facts relevant to the immunity issue will be precisely the same facts necessary for the evaluation of liability. For example, to determine whether a police officer made a reasonable mistake as to whether exigent circumstances justified a warrantless search, the parties and the court would have to explore the same basic facts concerning the officer's knowledge of exigent circumstances to adjudicate both the plaintiff's claim and the officer's qualified immunity defense.

Further support that qualified immunity has become a hybrid immunity comes from the judiciary's treatment of the role of juries in assessing qualified immunity. Notwithstanding its function as gatekeeper, qualified immunity can be asserted at many different stages

450. See Anderson v. Creighton, 483 U.S. 635, 646 n.6 (1987).

451. Seeid.

452. See id.; see also BRUNET ET AL., supra note $331, \S 6.10$ (noting that the Court in Anderson required that discovery be particularly geared to the question of the defendant's qualified im. munity). 
of the litigation process, including at, or even after, trial. ${ }^{453}$ When cases reach a jury, courts have had trouble defining what role juries should play in forming the court's legal judgment about whether the defendant violated clearly established constitutional rights. ${ }^{454}$ Some courts have addressed the issue by giving the jury "special interrogatories," which require it to make specific factual findings. ${ }^{45}$ These findings are then used by the court as a basis for making the "legal" determination of whether the defendant violated clearly established law. ${ }^{436}$

The very fact that courts must occasionally address the role of juries in qualified immunity analysis underscores the hybrid nature of the defense. Since qualified immunity is supposed to be a question of law, the jury's role should be irrelevant. At least one court has recognized, however, that courts can only determine whether a clearly established right has been compromised if they know what happened; they must know the historical facts of the incident. ${ }^{457}$ Yet, at the same time, the Supreme Court in Hunter $v$. Bryant ${ }^{458}$ admonished the Ninth Circuit for an analysis that "routinely places the question of immunity in the hands of the jury." itself evidence of qualified immunity's paradoxical qualities. The Court's language reflects some ambivalence, suggesting that there may exist some non-routine cases in which qualified immunity, a matter of law, would be placed in the jury's hands. ${ }^{460}$

Most seriously, the Court's creation of this "hybrid" immunity has severely complicated the task of defining the appropriate summary judgment standard for assessing qualified immunity claims. In Hunter, a divided Court could not agree on the correct standard. ${ }^{461}$ That case involved a plaintiff who sued two FBI agents after they ar-

453. See, e.g., King v. Macri, 993 F.2d 294, 299 (2d Cir. 1993) (allowing defendants to assert their claims of qualified immunity at trial).

454. See, eg., Warlick v. Cross, 969 F.2d 303, 306 (7th Cir. 1992) (overruling lower court's understanding of jury's role in qualified immunity determination). For an analysis of how courts have allocated different aspects of the qualified immunity determination to the judge and the jury and suggestions for how these decisions should be made, see Brands, supra note 227, at 1051-64.

455. See, e.g., Warlick, 969 F.2d at 305.

456. See, e.g., id.; Warren v. Dwyer, 906 F.2d 70, 76 (2d Cir. 1990).

457. See Elliott v. Thomas, 937 F.2d 338, 342 (7th Cir. 1991).

458. 502 U.S. 224 (1991).

459. Id. at 228. The Court asserted that the Ninth Circuit disregarded the significance of Supreme Court cases that stressed resolving questions of immunity at the preliminary stages of litigation. See id.

460. See id. (explaining that immunity should normally be determined before trial, thus leaving open the possibility that the determination may be made by a jury at trial in unusual circumstances).

461. See id. at 235 (Kennedy, J., dissenting) (describing Court's disagreement on the proper summary judgment standard). 
rested him in his home, allegedly without probable cause. ${ }^{462}$ The agents inferred that the plaintiff, Bryant, made a threat to the President when he appeared on a university campus carrying a rambling letter claiming that an unidentified "Mr. Image" was going to assassinate President Reagan. ${ }^{463}$ A witness told the agents that Bryant had also said that he [presumably the President] "should have been assassinated in Bonn," and that Bryant made various statements about "bloody coups," "assassination," and said something about "across the throat" while moving his hand horizontally across his throat to simulate a cutting action. ${ }^{464}$ After interviewing Bryant and searching his apartment with his consent, the agents arrested him under a federal statute making it a crime to threaten the President by knowingly or willfully depositing a letter or other document in the mail. ${ }^{465}$ Bryant was arraigned and held without bond for two weeks, after which the government dismissed the charges. ${ }^{466}$

Bryant then filed a Bivens action against the two agents, raising several claims. The trial court dismissed all of Bryant's claims except his contentions that the agents violated his rights because they arrested him without a warrant or probable cause. ${ }^{467}$ The court denied the defendants' summary judgment motion for qualified immunity on those two claims. ${ }^{468}$ On appeal, however, the Ninth Gircuit rejected the agents' immunity claim only with respect to Bryant's contention that they violated his Fourth Amendment rights by arresting him without probable cause. ${ }^{469}$ The court concluded that the agents had failed to sustain their "burden" of establishing qualified immunity. ${ }^{470}$ The agents claimed that they had probable cause, or a reasonable belief that there was probable cause, because they believed that "Mr. Image" referred to Bryant himself. ${ }^{471}$ The court disagreed, concluding that the agents' interpretation was not the most reasonable read-

462. See id. at 226.

463. See id. at 225.

464. See id.

465. See 18 U.S.C. $\$ 871$ (a) (1994). It is not clear how the agents understood the plaintiff to have violated the mailing element of the statute, but that was not an issue in the case. See Hunter, 502 U.S. at 225.

466. See Hunter, 502 U.S. at 226.

467. See id.

468. See id.

469. See Bryant v. United States Treasury Dep't, 903 F.2d 717, 723 (9th Cir. 1990), rev'd sub nom. Hunter v. Bryant, 502 U.S. 224 (1991). The Ninth Circuit held that the agents were entitled to qualified immunity on the warrantless arrest claim because it was not clearly established whether a person who consented to the entry of his home could be arrested without a warrant. See id. The general rule requires law enforcement officials to obtain a warrant in order to enter a person's home to arrest her. See Payton v. New York, 445 U.S. 573, 576 (1980).

470. See Bryant, 903 F.2d at 722.

471. See id. 
ing of Bryant's letter. ${ }^{472}$ The court felt that it was more reasonable for the police to conclude that Bryant's letter was providing a warning. ${ }^{43}$ Moreover, the court concluded that the qualified immunity issue, whether a reasonable officer could have believed she had probable cause, should be resolved by the trier of fact, and that further factual development was necessary before such a determination could be made."

Unfortunately, the Ninth Circuit framed its holding in an unclear manner. On one hand, the court accurately stated the conventional summary judgment standard as established in Liberty Lobby. ${ }^{475}$ The court held that the agents, as moving parties, could prevail on summary judgment only if the jury could reach but "one reasonable conclusion."tit This is simply the converse of stating that summary judgment must be denied if the nonmoving party presents evidence upon which a reasonable jury could return a verdict for that party. ${ }^{477} \mathrm{~A}$ reasonable jury could find that no reasonable officer could have believed probable cause to arrest Bryant existed in this case. On the other hand, the court went too far when it concluded that a "more reasonable" interpretation of Bryant's letter was possible. ${ }^{478}$

Focusing on the latter conclusion, the Supreme Court summarily reversed. ${ }^{\text {tia }}$ The Court held that the Ninth Circuit misapplied the law of qualified immunity when it denied summary judgment to the agents on the basis of a genuine dispute of material fact that required a jury to assess "whether a reasonable officer could have believed he had probable cause. ${ }^{+180}$ The Court held that the proper inquiry should be "whether the agents acted reasonably under settled law in the circumstances, not whether another reasonable, or more reasonable, interpretation of the events can be constructed five years after the fact. ${ }^{m \times 1}$ Thus, the Court concluded that the undisputed facts were sufficient to demonstrate that, at the very least, the agents made a reasonable conclusion that probable cause existed. ${ }^{4 \$ 2}$

\section{Sep id.}

473. See id.

474. See id. at 721 .

475. See id. at 719.

476. Id. at 721. Of course, this is the proper standard only assuming that the plaintiff bears the burden of persuasion on the qualified immunity defense. It is not clear under current law whether that is the case. See infra notes 566-91 and accompanying text.

477. See Anderson v. Liberty Lobby, Inc., 477 U.S. 242, 248 (1986) (explaining when summary judgment will be granted).

478. See Bryanl, 903 F.2d at 722.

479. See Hunter v. Bryant, 502 U.S. 224, 228-29 (1991).

480. Id. at 227-28 (quoting Byant, 903 F.2d at 721).

481. Id. at 228 .

482. Sep id. at 228-29. The Court also criticized the Ninth Circuit's statement of the sum- 
The Court was sharply divided on the appropriate summary judgment standard. Justice Scalia concurred in the result, but disagreed that the Ninth Circuit had applied an incorrect standard. ${ }^{483}$ He believed that the Ninth Circuit had identified the correct standard, but applied it incorrectly, although he did not elaborate on the specifics of that standard. ${ }^{484}$

Justice Stevens dissented because, although he believed the Ninth Circuit employed the appropriate standard, he also believed the appellate court correctly applied the standard in denying summary judgment. ${ }^{485}$ Consistent with his dissent in Anderson, Justice Stevens agreed with the court of appeals that summary judgment for the defendants was not appropriate in this procedural posture. He agreed with the Ninth Circuit's conclusion that the agents' reasonableness was a question for the trier of fact, and that summary judgment would be proper "only if there is only one reasonable conclusion a jury could reach." ${ }^{486}$ Justice Stevens concluded that while the officers may have had some evidence that Bryant was mentally unstable or delusional, they did not have sufficient evidence to establish probable cause that he had actually threatened the President. ${ }^{487}$ Because, under summary judgment rules, the facts must be read in the light most favorable to the nonmoving party (in this case, Bryant), Justice Stevens argued that the defendants should not have prevailed in their contention that a reasonable officer could have concluded that there was a sufficient basis for probable cause. ${ }^{488}$

Noting the substantial disagreement on the Court concerning the appropriate standard to be applied to summary judgment motions on qualified immunity grounds, Justice Kennedy dissented from the Court's summary resolution. ${ }^{489}$ Justice Kennedy was concerned that the Court's opinion provided insufficient guidance to lower courts and government officials. ${ }^{490} \mathrm{He}$ also expressed doubt about the Ninth Circuit's holding, stating that the majority opinion below did

mary judgment standard because "it routinely places the question of immunity in the hands of the jury," whereas immunity issues should "ordinarily" be decided by the court long before trial. See id. at 228.

483. See id. at 229 (Scalia, J., concurring in the judgment).

484. See id.

485. See id. at 229,234 (Stevens, J., dissenting).

486. Id. at 233 (internal citations omitted).

487. See id. at 230-32.

488. See id. at 234.

489. See id. at 234-35 (Kennedy, J., dissenting).

490. See id. at 235. 
not appear to consider all the facts on which the agents based their probable cause determination. ${ }^{491}$

Given its inartful explanation of the law, the Hunter decision has left lower courts in a quandary regarding the proper application of conventional summary judgment doctrine to qualified immunity claims. The direction these courts have taken, however, indicates that they recognize that factual issues often complicate, or even make impossible, the evaluation of qualified immunity under ordinary summary judgment standards.

\section{B. Lower Courts' Responses to the Hybrid Nature of Qualified Immunity- Contextual Alteration of Summary Judgment Doctrine}

The substantial factual component that is built into qualified immunity analysis has created problems in establishing a coherent analytical approach to adjudicating the defense. Specifically, as the Court's decision in Hunter highlights, these factual issues have made it more difficult to evaluate qualified immunity under the conventional framework of federal summary judgment law. Richard Marcus has argued that courts have responded to the unavailability or difficulty of obtaining summary judgment, particularly in areas of law such as antitrust, securities, and civil rights that raise complex factual issues or turn on the parties' state of mind, with a corresponding "revival of fact pleading." sponded to the ineffectiveness of summary judgment in filtering such claims by heightening the pleading standards and dismissing cases at an earlier stage of litigation. ${ }^{493}$

A similar pattern has emerged in response to the lower courts' problems administering the fact-based qualified immunity defense. The burden of adjudicating qualified immunity under the present analytical regime has generated two responses. First, some federal circuits have moved toward heightened pleading requirements, at least in cases in which the defendant's state of mind is an element of the alleged constitutional violation. Second, other lower courts have modified traditional summary judgment analysis in the context of qualified immunity claims.

491. See id. Justice Kennedy also thought the proper interpretation of the criminal statute, 18 U.S.C. $\$ 871$ (a) (1994), was an important question that likewise deserved full adjudication. See id. at 234-35.

492. Marcus, supra note 332, at 436.

493. See id. Courts have implemented heightened pleading requirements most often in the above mentioned areas of law, which the courts have perceived as contributing to the "litigation boom" burdening the federal court dockets. See id. 
Several circuits have required plaintiffs to meet heightened pleading standards when qualified immunity is asserted. In Elliott v. Perez, ${ }^{194}$ the Fifth Circuit adopted a heightened pleading requirement for all constitutional tort claims against officials who claim absolute or qualified immunity. ${ }^{45}$ Allowing such cases to go forward with discovery, the court argued, would reintroduce the same barriers to pretrial resolution that existed before Harlow and would undermine the very purpose of immunity by requiring the defendants to participate in potentially burdensome pretrial litigation. ${ }^{496}$ Perez held that in constitutional tort cases, trial courts must require a plaintiff to file "a detailed complaint alleging with particularity all material facts on which he contends he will establish his right to recovery, which will include detailed facts supporting the contention that the plea of immunity cannot be sustained." ${ }^{497}$ Thus, notwithstanding ordinary notice pleading requirements, plaintiffs must anticipate and plead around the affirmative defense of immunity.

The Ninth Circuit has adopted a similar heightened pleading requirement, but it has generally limited this requirement to cases in which the plaintiff asserts that the defendant acted with subjective intent to violate plaintiff's rights (or with some other requisite state of mind) ${ }^{498}$ Decisions in this Circuit have reasoned that in the absence of higher pleading burdens, plaintiffs in state of mind cases would be able to avoid summary judgment on qualified immunity grounds because state of mind issues often cannot be resolved without a trial. ${ }^{499}$ Thus, for the same reasons that the Supreme Court eliminated the subjective component of qualified immunity, the Ninth Circuit requires the plaintiff to assert some facts, based on either direct or cir-

494. 751 F.2d 1472 (5th Cir. 1985).

495. See id. at 1473. Although many lower federal courts also have imposed heightened pleading requirements for all civil rights claims, not just those in which qualified immunity was an issue, that topic is beyond the scope of this Article. For general discussions of heightened pleading requirements in civil rights cases, see Douglas A. Blaze, Presumed Frivolous: Application of Stringent Pleading Requirements in Civil Rights Litigation, 31 WM. \& MARY L. Riv. 935, 990 (1990) (concluding that heightened pleading for civil rights cases is not consistent with current structure of federal civil procedure); Blum, Heightened Pleading, supra note 264, at 62-63 (criticizing heightened pleading requirements and arguing for application of ordinary summary judgment procedures); C. Keith Wingate, A Special Pleading Rule for Civil Rights Complamls: A Slep Forward or a Step Back?, 49 MO. L. REv. 677, 693 (1984) (arguing against stricter pleading standard in civil rights cases).

496. See Peres, 751 F.2d at 1477-79.

497. Id. at 1482. As discussed below, the Fifth Circuit has replaced the Perez rule with a different procedural structure. See infra notes 506-07 and accompanying text.

498. See Branch v. Tunnell, 937 F.2d 1382, 1387 (9th Cir. 1991). The D.C. Circuit also had a strict heightened pleading requirement, but recently overruled its decisions imposing that requirement, replacing it with a new procedural structure. See infra notes 521-26 and accompanying text.

499. See Branch, 937 F.2d at 1386. 
cumstantial evidence, suggesting that the defendant had the requisite state of mind. .00 $^{50}$

The Supreme Court's decision in Leatherman v. Tarrant County Narcotics Intelligence and Coordination Unit, ${ }^{501}$ however, casts doubt upon the imposition of heightened pleading requirements. In Leatherman, the Court held that federal courts could not impose heightened pleading standards in $\S 1983$ civil rights claims asserting municipal liability because such claims were not among those that Rule $9(\mathrm{~b})^{502}$ excepts from the general pleading requirements of Rule $8(a) .^{503}$ The Court did not rule whether courts could adopt heightened pleading requirements under qualified immunity. ${ }^{504}$

Since the Court decided Leatherman, most circuits have continued to adhere to their earlier decisions requiring plaintiffs to meet a more substantial pleading burden..$^{505}$ In response to Leatherman, however, two circuits have modified their approaches to the heightened pleading issue. In Schultea $v$. Wood, ${ }^{506}$ the Fifth Circuit removed the Perez heightened pleading requirement and announced that it would "no longer insist that plaintiff fully anticipate the defense in his complaint at the risk of dismissal under Rule 12." ${ }^{507}$ Although the court denied that Leatherman controlled its decision, it adopted a new procedural requirement to guide trial courts in processing qualified immunity claims. ${ }^{508}$

Schultea held that once a defendant asserts a qualified immunity defense, the trial court may, in its discretion, order plaintiffs to file a reply under Rule $7(a){ }^{509}$ that responds to the defense with detailed, fact-specific assertions. ${ }^{510}$ The court observed that it could impose

500. Ser id. at $1386-87$.

501. 507 U.S. 163 (1993).

502. Rule 9 (b) requires more particularized pleadings regarding allegations of fraud or mistake than for other matters. See FED. R. Civ. P. 9(b).

503. Sep Leatherman, 507 U.S. at 168. Rule 8(a) (2) merely requires "a short and plain statement of the claim showing that the pleader is entitled to relief." FED. R. Crv. P. 8(a) (2).

504. See Latherman, 507 U.S. at 166-67.

505. See Blum, Heightened Pleading, supra note 264, at 75-87 (examining circuit court heightened pleading requirements after lealherman).

506. 47 F.3d I427 (5th Cir. 1995) (en banc). For an analysis endorsing the Fifth Circuit's approach in Schullea, based on policy considerations, but arguing that the Federal Rules must be amended in order to fully implement a reply requirement for qualified immunity claims, see Eric Kugler, Note, A 1983 Hurdle: Fillering Merilless Civil Rights Litigation at the Pleading Stage, 15 REv. LITIG. 551, 559, 564-65 (1996).

507. Schultea v. Wood, 47 F.3d 1427, 1430 (5th Cir. 1995) (en banc).

508. See id.

509. See FED. R. CIv. P. 7(a). Rule 7(a) defines the allowable forms of pleading, which include a "reply to a counterclaim denominated as such." Id.

510. See Schullea, 47 F.3d at 1432-34. The Sixth Circuit has adopted a similar approach, although it has not formally cast it in terms of a Rule 7 reply. See Veney v. Hogan, 70 F.3d 917, 922 (6th Cir. 1995) (holding that when a defendant asserts qualified immunity in a motion to 
such a requirement because the "short and plain statement" requirements of Rule 8 do not govern Rule 7 replies. ${ }^{\text {sl }}$ It also emphasized that the new rule was intended to narrow trial courts' discretion in ordering such replies. ${ }^{512}$ As with its decision in Perez, the Fifth Circuit did not limit its new procedural requirement to constitutional tort claims in which the defendant's state of mind was an issue. ${ }^{513} \mathrm{By}$ adopting this approach, the court avoided addressing the tension between the notice pleading requirements of Rule 8(a) and the policy rationale of limiting the burdens of pretrial litigation under qualified immunity.

Schultea, however, continued the improper focus on pleading rules as the appropriate procedural vehicle for vetting qualified immunity claims. ${ }^{514}$ In contrast, in Elliott v. Thomas, ${ }^{515}$ the Seventh Circuit articulated a heightened evidentiary burden for constitutional tort plaintiffs who seek to defeat qualified immunity claims where the defendant's state of mind is an element of the underlying constitutional violation. ${ }^{516}$ The court observed that it was misleading to characterize additional burdens on plaintiffs in responding to qualified immunity claims as pleading requirements. ${ }^{517}$ Instead, the court properly addressed the plaintiff's burden as involving "the minimum quantum of proof required to defeat the initial motion for summary judgment.."518 Although the court properly understood this issue as an evidentiary and not a pleading requirement, it nonetheless drew on Justice Kennedy's concurring opinion in Siegert $v$. Gilley. ${ }^{519}$ The court in Elliott stated that the plaintiff would be required to "produce 'specific, nonconclusory factual allegations which establish [the necessary mental state], or face dismissal." ${ }^{520}$

dismiss, the plaintiff must amend her complaint to include specific, non-conclusory allegations of fact that will enable the trial court to determine whether those facts, if proved, would overcome the qualified immunity defense).

511. See Schullea, 47 F.3d at 1433.

512. See id. at 1434 .

513. See id. at 1431.

514. See id. at 1432-33.

515. 937 F.2d 338 (7th Cir. 1991).

516. See id. at 345 .

517. Ser id.

518. Id.

519. See id. (citing Siegert v. Gilley, 500 U.S. 226, 236 (1991) (Kennedy, J., concurring)).

520. Id. at $344-45$ (emphasis added) (alterations in original) (quoting Siegert, 500 U.S. at 236 (Kennedy, J., concurring)). Other courts have since adopted a similar approach. See Sheppard v. Beerman, 94 F.3d 823, 828 (2d Cir. 1996) (adopting requirement that when defendant moves for summary judgment based on qualified immunity and the underlying constitutional claim requires a showing of improper motive, plaintiff must proffer particularized evidence of direct or circumstantial facts supporting motive claim); Gehl Group v. Koby, 63 F.3d 1528, 1535 (10th Cir. 1995) (adopting requirement that plaintiff must respond to summary judgment motion for qualified immunity by establishing legal motivation with specific and concrete evi- 
In Crawford-El v. Britton, ${ }^{521}$ the D.C. Circuit went even further, holding that there should be a heightened standard of proof for plaintiffs in state of mind cases. ${ }^{522}$ The court's earlier decisions not only had imposed a heightened pleading requirement for state of mind cases, but also had required the plaintiff to plead direct evidence of the defendant's state of mind in order to survive a pleading motion. ${ }^{523}$ In Crawford-El, the D.C. Circuit replaced the direct evidence pleading standard with a heightened evidentiary standard for defeating a defendant's summary judgment motion. ${ }^{524}$ First, it held that "[a] plaintiff cannot defeat a summary judgment motion unless, prior to discovery, he offers specific, non-conclusory assertions of evidence, in affidavits or other materials suitable for summary judgment, from which a fact finder could infer the forbidden motive."525 Thus, the Crawford-El rule forbids any discovery prior to plaintiff's response to the defendant's summary judgment motion on qualified immunity. Second, the court imposed a heightened evidentiary standard that requires the plaintiff, both at trial and on summary judgment, to carry the burden of proving by clear and convincing evidence that the defendant acted with the requisite state of mind in depriving the plaintiff of her constitutional rights. ${ }^{526}$

As argued above, however, the problems associated with factual disputes under qualified immunity are in no way limited to constitutional tort claims involving the defendant's state of mind. At least one other court has articulated a summary judgment standard for the qualified immunity defense in all contexts, thus making it more difficult for a constitutional tort plaintiff to survive summary judgment than for other plaintiffs. In Ellis $v$. Wynalda, ${ }^{527}$ the Seventh Circuit clearly laid out the precise burdens that plaintiffs responding to qualified immunity claims must meet. The case involved a $\$ 1983$ claim brought by a burglary suspect against a police officer who shot

dence).

521. 93 F.3d 813 (D.C. Cir. 1996) (en banc), cert. granted, 117 S. Ct. 2451 (1997).

522. See id. at 815 .

523. See Kimberlin v. Quinlan, 6 F.3d 789, 793-94 (D.C. Cir. 1993) (stating that a plaintiff charging a government official for constitutional deprivation must provide direct evidence of intent in the pleadings when the outcome depends on defendant's state of mind), vacated on other grounds, 515 U.S. 304 (1995).

524. See Crawford-EL, 93 F.3d at 815 .

525. Id. at 819 .

526. See id. at 821-23. This unprecedented heightening of the evidentiary burden for civil rights plaintiffs appears to be inconsistent with the Supreme Court's general presumption that the preponderance of evidence standard applies in most civil actions. See Grogan v. Garner, 498 U.S. 279,286 (1991) (stating that presumption is that preponderance of evidence standard applies unless "particularly important individual interests or rights are at stake." (quoting Herman \& MacLean v. Huddleston, 459 U.S. 375, 389-90 (1983))).

527. 999 F.2d 243 (7th Cir. 1993). 
him in the back during an arrest. ${ }^{528}$ Although the court rejected the officer's qualified immunity claim, it elaborated its understanding of the burdens associated with defeating that claim in important dicta.

The [qualified immunity] doctrine is valuable in order to describe the unusual "burden" on the non-moving party at the summary judgment stage. While ordinarily a court grants summary judgment only if no reasonable jury could find for the non-moving party, a court grants summary judgment based on qualified immunity if a reasonable officer could find the defendant's actions justified. When reasonable minds could differ, in the typical summary judgment decision the balance tips in favor of the nonmovant while in the qualified immunity context the balance favors the movant. ${ }^{53}$

This rather bold statement of the law acknowledges quite explicitly that the qualified immunity doctrine, at least in the Seventh Circuit, has not only transformed constitutional tort law, but also has reshaped the summary judgment doctrine.

Elliott, Crawford-El, and Ellis represent extraordinary transformations of summary judgment law to accommodate the unique factual nature of qualified immunity claims. To the credit of those courts, however, they do acknowledge the evidentiary component of the summary judgment standard for qualified immunity. To that end, they at least begin to approach the issue from an analytically coherent perspective (or at least from the most analytically coherent perspective possible).

At the same time, these decisions radically transform summary judgment law in a manner that substantially affects plaintiffs' rights to adjudicate constitutional tort claims. The D.C. Circuit's opinion in Crawford-El severely limits plaintiffs' opportunities to pursue ordinary discovery to collect evidence that will support their opposition to summary judgment. ${ }^{330}$ This seems at least partly inconsistent with Rule $56(f),{ }^{531}$ which affords trial courts discretion to permit some dis-

528. See id. at $245-46$.

529. Id at $246 \mathrm{n} .2$ (emphasis added) (citation omitted).

530. See Crawford-El, 93 F.3d at 819-23.

531. See FED. R. CIV. P. 56(f). What is more, the Crawford-El rule appears to be inconsistent with Rule 26 of the Federal Rules of Civil Procedure, which requires mandatory disclosure of basic discovery information. See FED. R. CIV. P. 26(a). Indeed, several of the reforms from the 1993 amendments to the Federal Rules may affect the manner in which the Court structures qualified immunity doctrine in future cases. For example, the presumptive limits on interrogatories and depositions, see FED. R. CIV. P. 30(a) (2) (A) and FED. R. CIV. P. 33(a), may streamline the process and minimize some of the relevant pretrial litigation burdens that have driven the Court's development of qualified immunity law. At the same time, Rule 26(a)'s mandatory disclosure requirements may ameliorate the harsh effects of the lower courts' responses to qualified immunity's factual nature by providing plaintiffs with some information that may allow them to respond meaningfully to a summary judgment motion. I am indebted to Steve Greenberger for pointing out to me the potential implications of the new discovery rules on qualified 
covery before a summary judgment motion is adjudicated. The decision also dramatically heightened the burden of persuasion for constitutional tort plaintiffs in state of mind cases in an unprecedented manner.

Even these harsh transformations, however, cannot completely eliminate the fact-based nature of the qualified immunity inquiry. Critically, the Crawford-El court distinguished discovery concerning an official's knowledge from discovery regarding that official's intent. $^{532}$ Discovery of the former, the court concluded, continues to be permissible under Anderson. ${ }^{533}$ Under the current doctrinal formulation of qualified immunity, however, factual disputes regarding the official's knowledge are as likely to exist as those surrounding her state of mind. ${ }^{534}$ Thus, these courts' efforts to expedite resolution of qualified immunity claims may not be entirely successful.

The Seventh Circuit's opinion in Ellis represents an equally alarming departure from ordinary summary judgment practice. The court's decision completely alters the burdens so carefully laid out in the Supreme Court's summary judgment trilogy. Under Liberty Lobby, if the defendant shifts the burden of production to the plaintiff (assuming the plaintiff has the burden of persuasion on this issue), the plaintiff may meet this burden by producing evidence sufficient to convince a reasonable jury to rule in her favor. ${ }^{535}$ But Ellis suggests that if reasonable minds could differ about the meaning of the evidence, a situation that typically would be regarded as suited for a trier of fact, then the defendant should prevail before trial, and the judge should dismiss the case. ${ }^{536}$

The consequences of such a rule, if widely accepted, would be astounding. The Ellis language implies that in order to overcome a defendant's summary judgment motion on qualified immunity grounds, the plaintiff must show that no reasonable jury could find for the defendant on the qualified immunity defense. ${ }^{537}$ This completely turns the tables on plaintiffs. Ellis converts the burden on a plaintiff, as the nonmoving party, from simply responding with evi-

immunity law.

532. See Crawford-El, 93 F.3d at 820-21; see also Act Up!/Portland v. Bagley, 988 F.2d 868, 873 \& n.3 (9th Cir. 1993) (noting that determination of whether genuine issue of material fact exists requires examination of facts regarding an official's conduct and knowledge, but not her intent).

533. See Crawford-El, 93 F.3d at 820 (citing Anderson v. Creighton, 483 U.S. 635, 640-41 (1987)).

534. See supra notes $163-69$ and accompanying text.

535. See Anderson v. Liberty Lobby, Inc., 477 U.S. 242, 248 (1986).

536. See Ellis v. Wynalda, 999 F.2d 243, 246 n.2 (7th Cir. 1993).

537. See id. 
dence that could lead a jury to return a verdict for her, to meeting the higher burden of a moving party who has the burden of persuasion at trial on the particular issue. Assuming that the plaintiff need only prove her case-in-chief by a preponderance of the evidence (which remains the general rule even after Crawford-El), the Ellis language requires the plaintiff to meet a higher burden just to survive a summary judgment motion than she would have to meet at trial to win the case on the merits. ${ }^{538}$

These developments reflect the complicated interpretive moves the lower courts must make in response to the hybrid nature of a factbased immunity analysis that is intended to resolve claims at the earliest stage of litigation. It is odd that these cases are modifying summary judgment procedure in a manner that may often preclude discovery on qualified immunity. This arguably conflicts with Rule 56(f), which provides trial courts with discretion to deny a summary judgment motion when the nonmoving party has not had an adequate opportunity for discovery. ${ }^{539}$ Moreover, these decisions alter the general understanding of summary judgment burdens, at least in this specific substantive context. ${ }^{5+0}$ As Judge Edwards contended in his concurring opinion in Crawford-El, the D.C. Circuit's adoption of special rules for constitutional torts with state of mind issues is "in complete defiance of the Federal Rules of Civil Procedure, inventing evidentiary standards out of whole cloth and overlaying them onto

538. One district court has made a similar observation about the requirement in some circuits that the plaintiff come forward with direct, and not merely circumstantial, evidence of the defendant's illegal motivation in order to survive a summary judgment motion on qualified immunity. See Verney v. Dodaro, 872 F. Supp. 188, 199 (M.D. Pa. 1995) (rejecting direct evidence standard for state of mind cases on ground that it would be illogical to require plaintiff to meet a higher burden in response to a summary judgment motion than she would need to show at trial), affd, 79 F.3d 1140 (3d Cir. 1996).

539. See FED. R. CIv. P. 56(f). Rule 56(f), in part, states: “[T] he court may refuse the application for judgment or may order a continuance to permit affidavits to be obtained or depositions to be taken or discovery to be had or may make any such other order as is just." Id.

540. A great deal of discussion surrounds the question of whether summary judgment and similar procedural rules should be transsubstantive, applied equally to all substantive areas of law. For a general discussion of the transsubstantive nature of summary judgment, see BRUNET ET AL., supra note $331, \S 6.01$. Nonetheless, a large body of summary judgment literature has questioned whether different standards may be necessary for certain areas of law that pose particular difficulties and policy concerns regarding pretrial resolution of claims. See, e.g., Robert Cover, For James Wm. Moore: Some Reflections on a Reading of the Rules, 84 YAL.. L. J. 718, 732-39 (1975) (exploring the tension between a transsubstantitive code and the need to address a particular substantive objective); Judith Resnik, Failing Faith: Adjudicatory Procedure in Decline, 53 U. CHI. L. Rrv. 494, 512 (1986) ("With a single paradigm, it is easier to overlook the saliency of the distinctions among various kinds of cases and hence to underestimate the need for rulemaking to take variation into account."). If courts deem qualified immunity to be an area of law that should be treated with different summary judgment rules, discourse regarding the benefits and costs of such a transformation ought to be broader and more explicit. 
the established procedures for adjudicating lawsuits in our federal courts."

Some courts have offered a specific justification for their interference with federal civil procedure rules for the purpose of facilitating summary resolution of qualified immunity claims. While recognizing that their decisions alter procedural rules of general applicability, these courts have concluded that to do otherwise would allow the rules of civil procedure to alter public officials' substantive right of qualified immunity, which would violate the Rules Enabling Act. ${ }^{5+2}$ On this view, courts have empowered themselves to tailor exceptions to the Federal Rules to ensure protection of qualified immunity rights.

But in enabling summary resolution of qualified immunity claims, the courts are also conceivably altering both constitutional tort doctrine and substantive constitutional law. Indeed, perhaps a better argument could be made that the right to remedial relief for constitutional violations, explicitly recognized by 42 U.S.C. $\S 1983$ and by Bivens, is a substantive one, and that a right not to be tried on a possible constitutional tort claim is procedural. ${ }^{543}$ Surprisingly, however, the courts have not addressed whether these judicially-created exceptions to the ordinary course of civil procedure might violate the Rules Enabling Act by altering the substantive rights of civil rights plaintiffs to enforce important constitutional rights.

Moreover, even accepting the lower courts' tinkering with summary judgment procedure to accommodate the policies underlying qualified immunity as legitimate, it is not altogether clear that such procedures offer much promise in facilitating early termination of civil rights claims. Ample opportunities for factual disputes remain. Even the D.C. Circuit in Crawford-El recognized that pretrial discovery may be necessary to explore what the official knew at the time of her actions. ${ }^{54}$ The Supreme Court's decision in Hunter also acknowledged that the factual circumstances facing the defendant are rele-

541. Crawford-El v. Britton, 93 F.3d 813, 847 (D.C. Cir. 1996) (en banc) (Edwards, J., concurring), cerl. granled, 117 S. Ct. 2451 (1997).

542. 28 U.S.C. $\$ 2072$ (b) (1994) (stating that the Federal Rules of Civil Procedure"shall not abridge, enlarge or modify any substantive right"); see Crawford-EL, 93 F.3d at 820 (concluding that the federal rules cannot be read to trump official's right to immunity); Schultea v. Wood, 47 F.3d 1427, 1436 (5th Cir. 1995) (en banc) (same).

543. See Elliott v. Thomas, 937 F.2d 338, 345 (7th Cir. 1991) ("[I]t is hard to depict a 'right not to be tried' as substantive; it sounds distinctly procedural.").

544. See Crawford-El, 93 F.3d at 819-20; see also Act Up!/Portland v. Bagley, 988 F.2d 868, 873 \& n.3 (9th Cir. 1993) (recognizing that it may be necessary to inquire into the officer's knowledge of the facts and circumstances in order to evaluate reasonable suspicion or probable cause). 
vant to the immunity inquiry. ${ }^{545}$ This is merely a different form of state of mind inquiry than one directed at motive.

These multifaceted efforts to refine the procedural details of litigating qualified immunity reflect the lower courts' frustration with the Supreme Court's inability to adequately articulate how to assign the various summary judgment burdens. Conceivably, what may be occurring without explicit discussion is that federal courts now view entitlement to qualified immunity not as a pure matter of law, but as a question of "ultimate fact." 546

Rather than following a strict dichotomy, a continuum exists between "pure" questions of law at one extreme and questions of "historical" fact at the other. ${ }^{547}$ Courts can resolve pure questions of law by the application of legal principles to a set of undisputed facts. ${ }^{54}$ For example, issues involving the meaning of a particular word in a statute or the Constitution are legal issues. ${ }^{549}$ If no disputed facts exist, the assessment of whether a necessary element of a claim or defense has been met is a purely legal one. ${ }^{550}$ In contrast, a "historical" fact is "a thing done, an action performed, or an event or occurrence, ${ }^{n 51}$ such as a trigger pulled, a fist swung, or a word spoken. The trier of fact has the responsibility of resolving disputes over historical facts, or concerning reasonable inferences to be drawn from such facts. ${ }^{52}$

The middle area of this continuum presents the most difficult analytical problems, but that may be where qualified immunity lies. Many litigated disputes center on the application of a legal rule or standard to a set of historical facts that are disputed. ${ }^{553}$ In some contexts, this hybrid question is characterized as a "mixed question of law and fact," which generally requires resolution of the historical fact issues before the legal issues. ${ }^{554}$ As Judge Schwarzer has observed, "[c]onstitutional issues, though generally questions of law, may be mixed questions when they turn on factual determinations."

545. See Hunter v. Bryant, 502 U.S. 224, 227-28 (1991).

546. See Schwarzer et al., Summary Judgment Motions, supra note 333, at 456-57 (describing "ultimate fact" as one that is "derived by reasoning or inference from evidence").

547. See id. at 45455 .

548. See id. at 455-56.

549. See id.

550. See id. at 455 .

551. Id.

552. See id.

553. See id. at 456.

554. See id.

555. Id. 
Another type of law/fact hybrid is what are often described as questions of "ultimate fact." Ultimate facts also involve the application of standards of law to particular facts, but have a decidedly more law-like aspect to them.

Ultimate facts present a different kind of "factual" inquiry, one involving a process that "implies the application of standards of law." Like some historical facts, ultimate facts are derived by reasoning or inference from evidence, but, like issues of law, they incorporate legal principles or policies that give them independent legal significance. They often involve the characterization of historical facts, and their resolution is generally outcome-determinative. ${ }^{556}$

Ultimate facts can be more "factual" (e.g., whether a driver recklessly or negligently operated an automobile), or more "legal" (e.g., whether a defamation plaintiff is a public figure for First Amendment purposes)..$^{557}$

The determination of whether the jury or the court should resolve a question of ultimate fact is a functional one. If the resolution of the question requires "an assessment of human behavior and expectations within the common experience" of the average person, then a jury should decide the issue..$^{58}$ The judge should resolve ultimate fact questions that relate to matters of law and policy and disputes involving technical issues underlying the legal scheme, as long as no evidentiary dispute exists. ${ }^{559}$ Legally-laden ultimate fact issues are those in which " $[t]$ he administration of the rules under which they arise benefits from consistency, uniformity, and predictability." other words, strong policy reasons suggest that the wiser course is for legal "experts" to resolve these questions. ${ }^{561}$

Although no court has made this assertion, one could argue that qualified immunity should be a question of ultimate fact because of its decided policy-orientation. In this manner, courts could more explicitly treat qualified immunity claims, even ones with factual complexities, as legal policy matters. ${ }^{562}$ Courts may already be follow-

556. Id. at 456-57 (internal citations omitted).

557. See id. at 457 .

558. See id.

559. See id.

560. Id.

561. See id. at 459; see also Bose Corp. v. Consumers Union of United States, Inc., 466 U.S. 485, $501 \mathrm{n} .17$ (1984) (asserting that in cases "[r] egarding certain largely factual questions in some areas of the law, the stakes-in terms of impact on future cases and future conduct-are too great to entrust them finally to the judgment of the trier of fact").

562. Judge Schwarzer has discussed this proposition briefly. See Schwarzer et al., Summany Judgmenl Molions, supra note 333, at 460 (suggesting that Anderson v. Creighton, 483 U.S. 635 (1987), can be understood as characterizing qualified immunity as a policy-based issued to be decided by courts). 
ing this course, whether consciously or not. Some courts have at least acknowledged that this analysis is conceptually possible. For example, Judge Posner wrote that "[i]t is unresolved whether the official can ask the district judge to find the facts, if they are contested, rather than letting the factual issues that bear on immunity be resolved by the jury (if there is a jury) along with the merits." ${ }^{563}$ Sound criticisms of this approach are also worth considering. ${ }^{564}$ Indeed, under ordinary summary judgment law, a judge is not permitted to "find" facts, a role properly left exclusively for the jury.

If courts are undertaking a sub silentio movement toward reconceptualizing qualified immunity as an ultimate fact question, it is unclear whether they comprehend what they are doing or the implications of their actions. Moreover, this transformation may be occurring without explicit recognition of or a proper appreciation for the source of the complications-the factual component of qualified immunityor for the serious policy ramifications of such a change. In addition, as Judge Norris has observed, the procedural complexities of administering a rule that treats at least some aspects of qualified immunity as ultimate fact questions need to be fully contemplated. ${ }^{566}$ It is incumbent upon the courts to explicitly discuss this issue and to engage in a public dialogue about the necessity for and implications of such a dramatic transformation in the conventional understanding of both qualified immunity and summary judgment.

\section{Understanding Burdens of Persuasion on a Legally-Based Affirmative Defense}

It is noteworthy that while the lower courts have struggled to modify summary judgment procedures to fit the special case of qualified immunity, they have failed to address a foundational question at the

563. Nelson v. Streeter, 16 F.3d 145, 149 (7th Cir. 1994) (citing Mahoney v. Kesery, 976 F.2d 1054,1058 (7th Cir. 1992); Jones v. City of Chicago, 856 F.2d 985, 994-95 (7th Cir. 1988)). The Seventh Circuit, without discussion, has once referred to qualified immunity as a question of ultimate fact, but has not undertaken an explicit evaluation of this issue. See Egger v. Phillips, 669 F.2d 497, 504 (7th Cir. 1982) (citing Askew v. Bloemker, 548 F.2d 673, 679 (7th Cir. 1976)), vacated on reh'g, 710 F.2d 292 (7th Cir. 1983) (en banc). Moreover, Egger suggested that the ultimate fact issue of qualified immunity should be resolved by a jury, see id., which is in conflict with the general understanding of the concept. For a general discussion of how courts have decided these issues should be allocated between the judge and the jury, see Brands, supra note 227, at 1051-56.

564. See Act Up!/Portland v. Bagley, 988 F.2d 868, 875-76 (9th Gir. 1993) (Norris, J., dissenting from denial of rehearing en banc) (observing that allowing judges a role in determining the "fact-bound" issue of reasonableness will create "procedural nightmares").

565. See Anderson v. Liberty Lobby, Inc., 477 U.S. 242, 255 (1986).

566. See Act up!/Portland, 988 F.2d at 875 (Norris, J., dissenting from denial of rehearing en banc). 
heart of summary judgment: where and how to allocate the burden of persuasion on a qualified immunity defense. A major controversy within summary judgment doctrine concerns the initial burdens on the party moving for summary judgment and the responsive burdens of the nonmoving party. Both issues are entirely dependent upon which party bears the burden of persuasion on the particular issue on which summary judgment is sought. Before courts may apply summary judgment procedure to a particular claim, therefore, they must first determine which party bears the burden of persuasion.

The Supreme Court has never clarified whether the plaintiff or the defendant bears the burden of persuasion on the defense of qualified immunity. ${ }^{567}$ In Gomez v. Toledo, ${ }^{568}$ the Court held that qualified immunity is an affirmative defense, and therefore, must be asserted by the defendant or waived. ${ }^{569}$ The Court specifically reserved the burden of persuasion issue, however, and has never returned to answer this critical question. ${ }^{570}$

While several commentators have observed the lack of a clear burden of persuasion under qualified immunity, they have generally failed to address the conceptual difficulty with the issue. ${ }^{57}$ Rather than acknowledge that a burden of persuasion on a question of law may be nonsensical, courts and commentators have attempted instead to dissect factual elements of the claim and propose assignments of the burdens of persuasion with respect to these different elements. ${ }^{572}$

The Court's failure to identify evidentiary burdens on the qualified immunity defense has left lower courts in the unenviable position of attempting to articulate the relevant burdens on summary judgment. The lower federal courts have struggled with this issue for years, never satisfactorily resolving the problem. ${ }^{573}$ The courts' attempts at

567. See Kinports, Unanswered Questions, supra note 28, at 634.

568. 446 U.S. 635 (1980).

569. See id. at 640 .

570. See id. at 642 (Rehnquist, J., concurring) (basing concurrence on understanding that the Court did not decide the burden of persuasion issue); see also Harlow v. Fitzgerald, 457 U.S. 800,815 n.24 (1982) (noting that Gomez did not decide burden of proof for qualified immunity claims).

571. See, r.g., Ignall, supra note 263, at 207 (noting unclear law on burden on persuasion for qualified immunity); Kinports, Unanswered Questions, supra note 28, at 634-42 (discussing how the Court in Harlow failed to make clear which party bears the burden of proof on the qualified immunity defense); A. Allise Burris, Note, Qualifying Immunily in Section 1983 E Bivens Actions, 71 TEX. L. REv. 123, 165-68 (1992) (noting confusion about burden of persuasion for qualified immunity).

572. See Kattan, supra note 235, at 986-89 (discussing burden of proof before Harlow); McKenzie, supra note 427, at 69495 (attempting to delineate the various burdens of persuasion derived from Harlow).

573. See, e.g., Gregorich v. Lund, 54 F.3d 410, 413 (7th Cir. 1995) (stating that plaintiff 
clarifying procedural and evidentiary burdens have been poorly conceived and betray a misunderstanding of the basic concepts of proof burdens on affirmative defenses. Even sophisticated federal appellate courts routinely demonstrate their lack of comprehension on this issue. ${ }^{574}$

Some federal courts of appeal, for example, have taken the position that the plaintiff bears the burden of showing that constitutional rights she asserts the defendant violated were "clearly established." 575 Some courts assign to the defendant the initial "burden" of proving that she was engaged in a "discretionary function." the plaintiff to not only "prove" that the law was clearly established, but also that the defendants' conduct violated that clearly established law. ${ }^{577}$ In contrast, some courts assign the defendant the burden of proving, or "demonstrating," that her actions were objectively reasonable. ${ }^{578}$ Other courts make that determination by analyzing the

"bears the burden of proof," an evidentiary burden, on the issue of qualified immunity, but citing cases in which courts conclude that plaintiff bears the burden of "establishing the existence of a clearly established right," a legal question (citing McGrath v. Gillis, 44 F.3d 567, 570 (7th Cir. 1995); Rakovich v. Wade, 850 F.2d 1180, 1209 (7th Cir. 1988) (en banc))).

574. See, e.g., id.

575. See, e.g., Lawshe v. Simpson, 16 F.3d 1475, 1483 (7th Cir. 1994) (holding that the plaintiff bears burden of showing that the law was clearly established when the defendant violated the plaintiff's rights); Elder v. Holloway, 975 F.2d 1388, 1392 (9th Cir. 1992) ("[T] he plaintiffs burden in responding to a request for judgment based on qualified immunity is to identify the universe of statutory or decisional law from which the court can determine whether the right allegedly violated was clearly established."), rev'd on other grounds, 510 U.S. 510 (1994); see also Hunter v. Bryant, 502 U.S. 224, 233 (1991) (Stevens, J., dissenting) (arguing that plaintiff "bears the burden of proving that the right which the defendants allegedly violated was clearly established").

576. See, e.g., Rich v. Dollar, 841 F.2d 1558, 1563-64 (11th Cir. 1988); Saldana v. Garza, 684 F.2d 1159, 1163 (5th Cir. 1982).

577. See, e.g., Romero v. Board of County Comm'rs, 60 F.3d 702, 704 (10th Cir. 1995) (acknowledging plaintiff must both articulate clearly established right and show how defendant's conduct violated that right), cert. denied, 516 U.S. 1073 (1996); Blackwell v. Barton, 34 F.3d 298, 301 (5th Cir. 1994) (placing burden on plaintiff "to come forward with summary judgment evidence sufficient to sustain a determination that [defendant's] actions violated clearly established federal law"); Bryant v. Muth, 994 F.2d 1082, 1086 (4th Cir. 1993) ("[T]he plaintiff carries the burden of showing that the defendant's alleged conduct violated the law and that such law was clearly established when the alleged violation occurred."); Taylor v. Bowers, 966 F.2d 4l7, 420 (8th Cir. 1992) (holding that even when plaintiff alleges acts that violate clearly established law, summary judgment is appropriate if plaintiff does not produce evidence that defendant in fact committed those acts). One court has even suggested that the defendant need only assert qualified immunity to shift the burden of production to the plaintiff to "demonstrate that the unlawfulness of the conduct was 'apparent' in the light of pre-existing law." Jantz v. Muci, 976 F.2d 623, 627 (10th Cir. 1992) (quoting Anderson v. Creighton, 483 U.S. 635, 640 (1987)). But see Tatro v. Kervin, 41 F.3d 9, 15 (1st Cir. 1994) (holding that it was inappropriate for trial court to instruct jury in a manner that seemed to heighten plaintiff's burden of proof to establish that defendants "clearly" violated law). Some courts only require plaintiff to meet this burden after the defendant has met the initial burden of showing that she was engaged in an exercise of discretionary authority. See Rich, 84I F.2d at 1563-64; Saldana, 684 F.2d at 1164-65.

578. See, e.g., Black v. Coughlin, 76 F.3d 72, 75 (2d Cir. 1996) ("Since qualified immunity is 
facts presented without requiring any demonstration on the part of the defendant, and in some cases requiring the plaintiff to submit evidence supporting the inference of objective unreasonableness. ${ }^{579}$

Much of the analysis in the lower court opinions that have recently modified summary judgment doctrine in the context of qualified immunity has ignored the critical burden of persuasion, or has implicitly assumed that it is borne by the plaintiff. For example, the entire procedural structure in Crawford-El implicitly depends upon the plaintiff bearing the ultimate burden of persuasion not only on the underlying constitutional tort claim, but also on the qualified immunity issue. ${ }^{5 \times 0}$ This must be the D.C. Circuit's assumption, because its decision not only allocates the burden of persuasion, but also elevates the evidentiary burden from the ordinary preponderance standard to a clear and convincing evidence standard. ${ }^{581}$ Similarly, the Seventh Circuit's decision in Ellis $v$. Wynalda effectively shifts the burden of persuasion on qualified immunity to the plaintiff by re-

an affirmative defense that the defendants have the burden of raising in their answer and establishing at trial or on a motion for summary judgment, a plaintiff, in order to state a claim of constitutional violation, need not plead facts showing the absence of such a defense.") (citations omitted); Guffey v. Wyatt, 18 F.3d 869, 871 (10th Cir. 1994) (asserting that defendant bears burden of establishing that her behavior was reasonable, given the circumstances); Mahers v. Harper, 12 F.3d 783, 785 (8th Cir. 1993) ("Qualified immunity is an affirmative defense, so defendants have the burden of pleading and proving the defense.");Elder, $975 \mathrm{~F} .2 \mathrm{~d}$ at 1392 (stating that once plaintiff carries initial burden, defendants must prove their actions were reasonable even though those actions may have been unconstitutional), rev'd on other grounds, 510 U.S. 510 (1994); Benigni v. City of Hemet, 879 F.2d 473, 479-80 (9th Cir. 1989) (holding that the qualified immunity defense, as an affirmative defense, requires that burden of proof be placed on the official asserting it).

579. See Orsatti v. New Jersey State Police, 71 F.3d 480, 484-86 (3d Cir. 1995) (asserting that undisputed facts of record established the "objective reasonableness" of defendants' conduct); Blackwell, 34 F.3d at 303 ("Couched in the terms of qualified immunity, however, we must address one further level of reasonableness [beyond probable cause] and ask ourselves whether a reasonable officer in Barton's position could believe that there was reasonable cause [to arrest plaintiff]."); Ellis v. Wynalda, 999 F.2d 243, 246 (7th Cir. 1993) (finding that an officer should be given qualified immunity if a "reasonable officer" under similar circumstances would have perceived same need for use of deadly force). But see Shaw v. Stroud, 13 F.3d 791, 801 (4th Cir. 1994) (requiring plaintiffs to demonstrate that defendant lacked qualified immunity by showing that defendant's conduct violated clearly established law and that a reasonable person would have known that defendant's actions were unlawful); Hall v. Lombardi, 996 F.2d 954, 958 (8th Cir. 1993) ("To demonstrate that the law is 'clearly established,' there must be a showing that 'a reasonable official would understand that what he is doing violates' plaintiff's rights." (quoting Anderson, 483 U.S. at 640)); Gooden v. Howard County, 954 F.2d 960, 965-66 (4th Cir. 1992) (holding that summary judgment with respect to qualified immunity claim was appropriate because no evidence was presented that would show that the officers' actions were unreasonable); Pfannstiel v. City of Marion, 918 F.2d 1178, 1183-84 (5th Cir. 1990) (assigning to plaintiff burden of establishing that it was objectively unreasonable for defendants to believe that they had probable cause to arrest).

580. See Crawford-El v. Britton, 93 F.3d 813, 821-23 (D.C. Cir. 1996) (en banc), cert. granted,

117 S. Ct. 2451 (1997).

581. See id. 
quiring the plaintiff to show that no reasonable jury could find for the defendant on qualified immunity. ${ }^{582}$

Independent of the normative question of whether the burden should be allocated this way, students of qualified immunity should be concerned about the unthinking manner in which this shift may be taking place. The doctrinal and practical implications of these decisions must be fully understood in light of the factual nature of qualified immunity. If this factual component were acknowledged, perhaps the allocation of these fundamental burdens would not so confound the courts. "Burdens" are generally associated with obligations to produce evidence, rather than to persuade the court on a matter of law. In order to clarify these important burdens, it is useful to compare constitutional torts and qualified immunity to common law torts and other affirmative defenses.

If a common law tort defendant moves for summary judgment on the basis of the weakness of a plaintiff's evidence, she may argue that no genuine fact issue exists concerning some essential element of the plaintiff's claim. Suppose, for example, a defendant seeks summary judgment on a battery claim and that she claims that no genuine issue exists as to a material fact-say, whether a touching occurred. The defendant may shift the burden of production to the plaintiff by "showing" that the record is devoid of any genuine fact issue. ${ }^{583} \mathrm{Be}-$ cause the plaintiff bears the ultimate burden of persuasion on all elements of her claim, she would then, under Liberty Lobby, have the burden of producing evidence from which a reasonable jury could find that the defendant touched the plaintiff. ${ }^{584}$

These burdens are substantially different in the context of an affirmative defense. Suppose the battery defendant in the above example asserts a consent defense, and seeks summary judgment on those grounds. ${ }^{585}$ The burden of persuasion at trial for the affirmative defense of consent would be on the defendant. ${ }^{586}$ Accordingly, on summary judgment, the defendant would have to demonstrate

582. See Ellis, 999 F.2d at 246 n.2.

583. See Celotex Corp. v. Catrett, 477 U.S. 317,325 (1986).

584. See Anderson v. Liberty Lobby, Inc., 477 U.S. 242, 252 (1986).

585. Under the common law, some dispute exists as to whether the plaintiff under torts such as battery must affirmatively prove the lack of her consent, or whether consent constitutes an affirmative defense, and therefore must be pled and proved by the defendant. See DOBBS ET Al., PROSSER AND KEeton ON TORTS $§ 18$ (5th ed. 1984). It is clear, however, that for some intentional torts consent can be construed as an affirmative defense, as set forth in the example in the text. See id. $\$ 18 \mathrm{n} .2$ (noting that consent is an affirmative defense to trespass to land and that defendant accordingly bears burden of proof).

586. See Smith v. City of Des Moines, 99 F.3d 1466, 1471 (8th Cir. 1996) (allocating burden of persuasion to defendant on affirmative defense of business necessity in age discrimination case); see also DOBBS ET AL., supra note 585, \$18 n.2. 
that even viewing the facts in the light most favorable to the plaintiff, no reasonable jury could find for the plaintiff on the consent issue. ${ }^{587}$ Because the relevant burdens of persuasion are allocated differently, the defendant's burden is much higher to achieve summary judgment on an affirmative defense than it is simply to defeat the plaintiff's case-in-chief. Because most conventional affirmative defenses generally involve a factual component, the burdens of persuasion and the associated burdens on summary judgment would be similar in other contexts as well.

Applying these burdens in the context of qualified immunity has proven to be troublesome because the nature of the defense is not entirely dependent upon historical fact. It seems meaningless to assign an evidentiary burden to any party when the underlying issue is the clarity of the constitutional rights asserted in the plaintiff's claim. $^{5 \times *}$ If that is true, then what does it mean for a party to have the burden of persuasion-an evidentiary standard-on a (supposedly) purely legal question?

These questions are complicated, but crucial. Before courts can properly assign the respective evidentiary burdens to the moving and nonmoving parties on a summary judgment motion asserting qualified immunity, they must ascertain who bears the burden of persuasion on the immunity defense. Furthermore, as with any qualified immunity inquiry, the question cannot be answered in the abstract; it must be related to some set of facts, whether the plaintiff's allegations, the defendants' version of the facts after discovery, or the fact finder's conclusions. Thus, the assignment of an evidentiary burden may still be necessary to adjudicate the defense.

Assuming that an evidentiary burden could be assigned on qualified immunity, it is worth conceptualizing what that burden would look like, how it would be assigned, and how it would operate. ${ }^{589}$

587. See Celolex, 477 U.S. at 331 (Brennan, J., dissenting); Fitzpatrick v. City of Atlanta, 2 F.3d 1112,1114 (11th Cir. 1993) (describing how when party with burden of persuasion moves for summary judgment, it must show that on all elements of its claim, no reasonable jury could find for the nonmoving party (citing United States v. Four Parcels of Real Property, 941 F.2d 1428, 1438 (11th Cir. 1991) (en banc))).

588. NAHMOD, supra note $54, \$ 8.19$ ("As to the question of the existence of clearly settled law, to speak of a burden of proof with its evidentiary emphasis appears misplaced.").

589. A comprehensive and normative analysis of the considerations that should affect the allocation of the burden of persuasion on qualified immunity is beyond the scope and ambition of this Article. For a sampling of interesting accounts of how the law should assign burdens of persuasion, see JAMES ET AL., supra note 423, \$ 7.16; Edward W. Cleary, Presuming and Pleading: An Essay on Juristic Immunity, 12 STAN. L. Rtv. 5, 8-16 (1959) (explaining the fundamental considerations relevant to the allocation of pleading and persuasion burdens); Bruce $\mathrm{L}$. Hay, Allocaling the Burden of Proof, 72 IND. L.J. 651 (1997) (developing economic model for optimal allocation of burden of proof designed to minimize both the costs of processing disputes and the costs of erroneous outcomes); Thomas R. Lee, Pleading and Proof: The Economics of Legal 
First, of course, unlike with other conventional affirmative defenses, the law could assign the burden of persuasion on qualified immunity to the plaintiff. The plaintiff already bears the burden of persuasion on the elements of the underlying constitutional tort. Thus, if she somehow gets to trial, she must establish by a preponderance of the evidence that each element of her claim is true. If the burden of persuasion to overcome the defendant's qualified immunity claim also lies with the plaintiff, she must now bear an additional evidentiary burden. $^{590}$ In addition to proving that the defendant violated her constitutional rights, the plaintiff must establish by a preponderance of the evidence that the defendant violated a clearly established constitutional right.

What, in turn, would this entail? What additional facts, other than those that she must already establish, could the plaintiff put before the jury? A great deal of confusion would no doubt arise under such a scenario. One problem is that the qualified immunity inquiry, as presently constructed, is very closely related to an examination of the merits of the plaintiff's claims. Thus, it remains unclear what facts, if any, would be different in the plaintiff's case-in-chief as compared to her "proof" on the qualified immunity defense. In the diagram below, for example, it is difficult to conceptualize what facts the plaintiff could prove that would move her case from category B (unconstitutional, but reasonable, conduct) to category A (unconstitutional and unreasonable conduct).

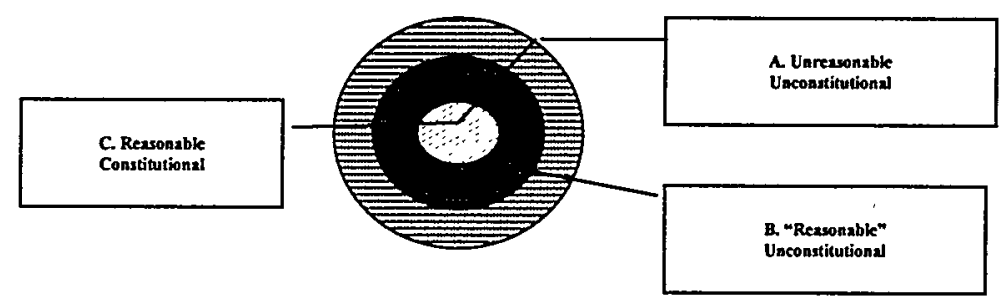

Even assuming one could sort out this complex evidentiary and procedural mess, assignment of the burden of persuasion to the plaintiff would have serious legal ramifications. It is at least clear that

Burdens, 1997 BYU L. REV. 1 (using economic analysis to explain law's allocation of pleading and proof burdens as methods for minimizing social costs).

590. See, e.g., Bryant v. Muth, 994 F.2d 1082, 1086 (4th Cir. 1993) (“[O]nce the defendant raises a qualified immunity defense, the plaintiff carries the burden of showing that the defendant's alleged conduct violated the law and that such law was clearly established when the alleged violation occurred." (citing Dixon v. Richer, 922 F.2d 1456, 1460 (10th Cir. 1991))). 
assigning the burden to the plaintiff would mean that she must prove more than she would in order to prevail on the merits. Heightening the evidentiary burden the plaintiff would have to bear at trial on qualified immunity would, in essence, transform substantive constitutional law, at least in constitutional tort cases; the heightened evidentiary standard would essentially change the meaning of constitutional law in the constitutional tort context. This covert transformation of substantive constitutional law would both be unfair and create substantial inequalities in constitutional law enforcement. Moreover, the alteration of substantive law in this manner would occur subversively because it would be achieved at a sub-doctrinal level. The subtle change occasioned by allocating the burden of persuasion to the plaintiff would not consciously be acknowledged in the substantive constitutional law. Furthermore, putting the persuasion burden on the plaintiff would make overcoming the immunity defense an element of plaintiff's case-in-chief, which arguably conflicts with the Court's holding in Gomez $v$. Toledo that qualified immunity is an affirmative defense. ${ }^{591}$

Alternatively, the law could assign the burden of persuasion to the defendant, the conventional allocation for affirmative defenses. ${ }^{592}$ Here, too, courts would face substantial difficulty in precisely defining what the burden of persuasion at trial would look like. Under one scenario, the defendant could bear the burden of persuading the fact finder by a preponderance of the evidence that the plaintiff's version of the facts is not true. But that characterization makes no sense, because that would be the equivalent of shifting the burden of persuasion on the merits to the defendant to disprove elements of the plaintiff's claim. It would be unfair to assign the burden of persuasion to the defendant to simply defeat an element of the plaintiff's claim, because that would be more than she would need to show in order to win on the merits (which would require her merely to argue that the plaintiff has not met her persuasion burden on that element).

Another possibility is to assign the defendant the burden of persuading the fact finder that the facts are such that a reasonable offi-

591. Ser Gomez v. Toledo, 446 U.S. 635,640 (1980). There are circumstances in which the law places the burden of persuasion on the plaintiff to overcome an affirmative defense, although that is not the norm. See generally Sowle, supra note 195, at 400-01 (observing that in areas of law involving affirmative defenses analogous to qualified immunity, Court usually places burden of persuasion and burden of pleading on defendants).

592. See FRIFDENTHAL. ET AL.,, supra note $417, \$ 5.20$ (noting that burden of pleading usually falls on party with burden of proof on that issue, which is generally the defendant on affirmative defenses). 
cer could have been mistaken as to whether her conduct violated the Constitution. As discussed above, this too would be intertwined with the facts on the merits. It might be difficult to sort out which facts are a part of the plaintiff's case-in-chief and which are associated with the reasonableness defense. Thus, what the defendant must prove would be a more subtle or nuanced factual issue. At the very least, jury instructions would be confusing.

Indeed, this might present the jury with dueling burdens. The jury instructions, for example, might provide the following guidance:

If the plaintiff persuades you by a preponderance of the evidence that each of her allegations is true, then you must return a verdict for the plaintiff. If, however, the defendant persuades you by a preponderance of the evidence that, on her version of the facts, a reasonable official in her position might not have believed that her conduct was unconstitutional, then you must make a factual finding that her version of the facts is true and report that to the court. At this point, if the jury found that the defendant had met her persuasion burden, it would report that finding to the judge, who would have to direct a verdict for the defendant on qualified immunity. But this scenario may not even make sense. If the jury must decide on the defendant's set of facts, it still must do so with reference to some legal standard. But by referencing the "reasonable official," the court is directing the jury to make at least a quasi-legal determination.

There is surely no easy answer to any of these questions, but the federal courts have done a woefully inadequate job of even identifying the essential and foundational issues that must be resolved before these various burdens can be sorted out. Until that occurs, the confusion, and the corresponding administrative burdens, will continue.

\section{UNDERSTANDING THE PRACTICAL CONSEQUENCES OF QUALIFIED IMMUNITY'S FACTUAL NATURE-THE CREATION OF SECONDARY BURDENS}

The principal pragmatic consequence of the doctrine's factuallydependent analysis is an increased likelihood that constitutional tort cases in which qualified immunity is asserted will involve a complex factual analysis. As this Article has explained in greater detail above, factual disputes under the law of qualified immunity are not unlikely, given the open-ended reasonableness standard by which assertions of the defense are to be evaluated. ${ }^{593}$ Accordingly, the possibility that the immunity claim can be resolved at an early stage of the litigation 
becomes more remote. Even assuming that the defendant can escape trial, substantial attention will have to be paid to the pretrial litigation process, including discovery. Plaintiffs, defendants, and trial courts are likely to expend substantial resources simply litigating the qualified immunity defense-an elaborate sideshow, independent of the merits, that in many cases will do little to advance or accelerate resolution of the legal claims. More significant is the high probability that the trial court will conclude that the factual issues underlying qualified immunity claims raise genuine issues of material fact. If that is true, then qualified immunity cases ought not to be easily resolvable on summary judgment, and many cases should go to trial.

Given that the acknowledged goal of qualified immunity is to minimize the social costs of constitutional tort litigation, it would be at best ironic if qualified immunity not only failed to advance this objective, but also generated independent social costs. Yet this appears to be the case. The heavily factual nature of qualified immunity creates a phenomenon that can be called "secondary burdens"- the social costs specifically generated by the litigation of the qualified immunity defense.

Under the present system, even if the defendant prevails on a qualified immunity claim at some point prior to trial, the factual component of the immunity inquiry may mean that she already has been subjected to much of the litigation burden attendant to a case that was tried on the merits (other than the trial itself). As the Court has acknowledged, at least some discovery, and perhaps fairly extensive discovery, may be necessary to flesh out the precise nature of the defendant's conduct. ${ }^{594}$ This will generate substantial litigation burdens on defendants, whether they are vindicated prior to trial or not. This process similarly taxes plaintiffs and the court system.

Moreover, if the defendant prevails on the immunity defense, it is surely possible that she might have prevailed at a trial on the merits. This may be true for two reasons. First, if the factual scenario is such that it is not clear whether the defendant violated the plaintiff's clearly established constitutional rights, it is one in which a jury might conclude that no substantive violation of the Constitution has occurred. After all, the cases in which qualified immunity is likely to be meaningful are already the close ones. Second, qualified immu-

594. See Anderson v. Creighton, 483 U.S. $635,646-47$ n.6 (1987). Indeed, some cours have used special interrogatories to juries to find the relevant facts and then have applied the "clearly established" law to those facts. See supra notes 454-55 (citing cases utilizing this approach). 
nity could, even if not resolvable prior to a trial, be asserted as a substantive defense to liability. ${ }^{595}$

Therefore, it is not clear that the liability outcome fostered by immunity would necessarily be different from the outcome at trial in many cases. This has two implications. First, concerns about fairness and overdeterrence might still be accommodated at trial even if the defendant and society bear some social costs prior to the ultimate vindication on liability. Second, it is not even clear that the qualified immunity defense saves substantial social costs. Assuming that the defendant might prevail in many cases, whether on immunity grounds or on the merits, the costs eliminated by resolving the case prior to trial must be compared to the costs of trying the case. A comparison of a system with and without immunity reveals that the immunity phase of the pretrial litigation, however costly, is a substitute for the costs of the trial. In other words, the pretrial litigation costs caused by the invoking of the immunity defense may cancel out the trial costs saved by that defense.

Although trials are certainly costly, the costs of litigating immunity claims may also be quite significant. One scholar has noted anecdotal evidence that federal district court judges perceive that defendants use the qualified immunity interlocutory appeal process to protract litigation "that would otherwise be tried or settled relatively quickly." ${ }^{596}$ In opposing multiple interlocutory appeals in the Behrens case, the plaintiff pointed out that the litigation of the first interlocutory appeal on qualified immunity delayed the case for four years. ${ }^{597}$ While this, too, is anecdotal, it demonstrates the possibility that immunity litigation may be costly for all involved.

If the comparative costs of pursuing qualified immunity claims (and bearing the associated costs of pretrial litigation) and going to trial were borne only by official defendants, then assessing these costs might be considerably less important. Rational defendants in such cases could decide whether the benefits of asserting qualified immunity at the pretrial stages would be outweighed by the additional costs it imposes. As with the other costs of constitutional tort litigation, however, these costs are not realized solely by defendants. Plaintiffs, courts, and society are also saddled with additional costs that might not otherwise exist in a world without qualified immunity.

595. See Andersom, 483 U.S. at 653 (Stevens, J., dissenting).

596. See Michael E. Solimine, Revitalizing Interlocutory Appeals in the Federal Courts, 58 GEO. WASH. L. REV. 1165, 1191 (1990).

597. See Brief for Respondent at 40, Behrens v. Pelletier, 516 U.S. 299 (1996) (No. 94-1244). 
What is more, the previous discussion assumes that courts can adequately resolve qualified immunity claims on summary judgment. But the factual nature of qualified immunity also may generate irresolvable genuine fact issues. ${ }^{598}$ Indeed, the Court's recent attention to the details of interlocutory appeals of qualified immunity claims suggests that trial courts may be denying a substantial percentage of qualified immunity claims.

Thus, a comprehensive analysis of the practical effects of the factual component of qualified immunity must also examine cases at the other end of the spectrum. If the defendant loses her qualified immunity claim, and the plaintiff ultimately prevails on the merits at trial, the entire immunity portion of the litigation will have significantly driven up the litigation costs, the plaintiff's attorneys' fees (for which the defendant may well be liable), ${ }^{600}$ and the resources that the trial court has devoted to the case. Furthermore, in cases where the defendant pursues multiple interlocutory appeals on her immunity claim prior to the plaintiff's victory, the costs may be even more substantial. Thus, the Court may be exacerbating the social costs of immunity litigation by widening the availability of such appeals. ${ }^{601}$

If this is all that qualified immunity accomplishes, the principal policy rationale for its existence under the modern cases-the minimization of the social costs of constitutional tort litigation-may itself have been undermined. In other words, the elimination of qualified immunity might actually lower the overall social costs of constitutional tort litigation.

This is not to say that qualified immunity does not also substantially limit some of the social costs of constitutional tort litigation. Even in a case in which the defendant does not prevail on a qualified immunity claim until years of discovery and summary judgment procedures have passed, she still has saved herself and the court the considerable expense of a trial as well as the additional psychological burden associated with the risk of liability whenever one goes to trial.

598. See Kinports, Unanswered Questions, supra note 28, at $647-48$ n.203 (citing substantial numbers of federal appellate cases in which a factual dispute precluded resolution of qualified immunity by summary judgment).

599. As Professor Solimine points out, however, a substantial percentage of those claims have been reversed. See Solimine, supra note 596, at 1190 . Professor Solimine acknowledges that the data on which this reversal rate was calculated should be viewed with some caution. See id. at 1190 n. 137 .

600. Siee 42 U.S.C. $\$ 1988$ (b) (1994 \& Supp. 1997) (granting court discretion to award prevailing party reasonable attorneys' fees).

601. See Behrens v. Pelletier, 516 U.S. 299, 321-22 (1996) (Breyer, J., dissenting) (asserting that additional appeals generated by qualified immunity cases will threaten federal appellate system with overloaded dockets). 
The point is simply that a meaningful assessment of the costs saved by qualified immunity must be measured against the costs imposed by qualified immunity. If qualified immunity litigation generates significant secondary burdens, those burdens should be evaluated relative to the putative savings promoted by the pretrial vetting of constitutional tort claims. It would be useful, for example, to know the overall costs of constitutional tort litigation presently, and compare those to costs under a system that requires defendants to defend cases on the merits.

Unfortunately, this is all speculation. Presently, there is no empirical foundation for the advocates of the present qualified immunity doctrine or its critics. While the Court has consistently hypothesized that significant social costs are engendered by $\S 1983$ and Bivens litigation against individual government officials, ${ }^{602}$ it has never relied on empirical data concerning the impact of constitutional tort litigation on officials' actual behavior. ${ }^{603}$ Similarly, while other commentators also have observed that qualified immunity litigation may generate substantial social costs, they have offered no supporting empirical data either. ${ }^{60 t}$ The Court itself has rarely questioned whether social costs are created by the very procedure it has designed for limiting those suits. ${ }^{605}$

Empirical research into the social costs of all aspects of constitutional tort litigation would contribute meaningfully to the continuing discourse about the appropriate scope of $\S 1983$ and Bivens actions.

602. See, e.g., Harlow v. Fitzgerald, 457 U.S. 800, 814 (1982).

603. See supra note 92 and accompanying text (noting observations of commentators that there is no empirical basis for any of the Court's underlying assumptions about the necessity of qualified immunity). In contrast, the Court recently rejected a claim of absolute immunity for court reporters on the ground that no empirical basis existed to suggest that a significant volume of vexatious and burdensome actions against court reporters would result in the absence of such immunity. See Antoine v. Byers \& Anderson, Inc., 508 U.S. 429, 437 (1993).

604. See, e.g., Blum, User's Manual, supra note 14, at 189 (noting without empirical support the costs of the qualified immunity defense and concluding that the costs of the defense outweigh its benefits); Burris, supra note 571, at 186 ("[The] true litigation explosion in Section 1983 is in immunity claims, not filings."); Kuhn, supra note 227, at 682 (noting that qualified immunity "has become a complex and exploding aspect" of constitutional tort litigation, but not citing empirical data).

605. The Court has, on occasion, recognized some social costs surrounding vindication of the immunity defense. See Mitchell v. Forsyth, 472 U.S. 511, 526 (1985) (observing that interlocutory appeals for public official defendants may add social and institutional costs to the adjudication of constitutional tort claims).

606. Ted Eisenberg and Stewart Schwab have done the most important and comprehensive empirical research on \$ 1983 litigation to date. See Theodore Eisenberg \& Stewart Schwab, The Reality of Conslitulional Torl Liligation, 72 CORNELL L. REV. 641, 642-43 (1987) (detailing empirical study of $\S 1983$ litigation in the federal courts and concluding that claims that such litigation is overrunning the federal judiciary may be exaggerated). Although it is beyond the scope of this Article to define the scope or methodology of such empirical examination, it is surely worthwhile to at least mention some of the potential areas for empirical research and their cor- 
For example, whether one believes that the Court has engaged in judicial activism in crafting the qualified immunity doctrine ${ }^{607}$ or that it has legitimately interpreted congressional intent with reference to common law, ${ }^{608}$ it seems that the future of the qualified immunity doctrine ought to be based on some empirical foundation. Whether this responsibility belongs to Congress or the federal courts, the first step toward reforming the constitutional tort system should be the acquisition of reliable data.

Examination of empirical data might also provide a better foundation for normative debates about immunity. By definition, qualified immunity creates a barrier to recovery for some meritorious claims. It sacrifices the enforcement of constitutional values in those cases in order to protect other values that are not formally based in the Constitution: fairness, overdeterrence, and social costs. As a normative matter, it would seem that there are substantial justifications for requiring compelling reasons to overcome what some might consider to be a presumption of constitutional enforcement.

\section{CONCLUSION}

This Article has explored the burdens of qualified immunity, drawing on the multiple meanings of "burden" in this doctrinal context.

responding limitations. One basic issue would be the identification of potential sources for data about the costs of constitutional tort litigation and, by comparison, what percentage of those costs are attributable to the immunity component of the litigation. Researchers could examine evidence of the resources spent by all players in constitutional tort cases, focusing on relevant cost categories, such as plaintiffs' and defense attorneys' time, official defendants' time spent on litigation, actual out-of-pocket costs, and judicial resources devoted to the case. It might be difficult, however, to compile evidence of attorney or official defendants' time and resources, given that time records might not be maintained or, if maintained, may be privileged. Furthermore, the inquiry would have to factor out other variables that might cause some types of constitutional tort cases to be more costly than others, such as complexity of the legal or factual issues, the number of parties and witnesses involved, and the doctrinal source of the underlying constitutional violation.

Alternatively, or as a supplement, researchers could look to reported decisions on qualified immunity to assess whether significant percentages of cases are not resolvable because of factual issues, and evaluate the average time from filing to resolution. But, of course, reported decisions (and even unreported ones) do not reflect all of the information pertinent to this inquiry. First, the information would be incomplete. Evaluation of judicial decisions would not account for the unknown number of cases that are never filed because the qualified immunity doctrine exists as an anticipated barrier to success. Second, some qualified immunity determinations may not generate a written opinion, particularly if the basis for the denial of a claim is the existence of a factual dispute. Rather, the court may resolve them in short, unreported orders.

Finally, researchers could also look for anecdotal evidence about the social costs of qualified immunity. Each of these sources has potential limitations.

607. See Rudovsky, supra note 14 , at 25 (arguing that judicial activism has characterized the development of the qualified immunity doctrine).

608. See Wyatt v. Cole, 504 U.S. 158, 163-65 (1992) (discussing common law roots of qualified immunity doctrine). 
First, the Court has generated burdens on judges and practitioners who must dissect this extraordinarily complex doctrine and apply it sensibly in the litigation world. Second, the doctrine has created secondary burdens on the federal courts by requiring detailed factual inquiries in virtually all qualified immunity claims, thus belaboring the resolution of claims and requiring doctrinal gymnastics in the articulation of the appropriate legal standard and the application of that standard to cases. Finally, the doctrine must somehow be fit into the various summary judgment burdens-the burden of production or highlighting, and the burden of persuasion-that are essential to applying the qualified immunity standard and conventional summary judgment law.

In examining the burdens of qualified immunity, this Article has identified some important conceptual issues surrounding the qualified immunity doctrine and its application. A proper understanding of the factual component of qualified immunity should lead courts, practitioners, policymakers, and litigators to a better comprehension of how better to apply the doctrine, and perhaps how to modify it. Before the legal system can make any significant progress toward refining this burdensome doctrine, the Court must take the modest step of acknowledging the paradox it created when it shaped the doctrine to require a substantially fact-based inquiry.

Finally, the burdens of qualified immunity should teach us something broader about how law is crafted. The story of qualified immunity's doctrinal development should be a sobering one. It shows us that the law sometimes turns on itself because of our ambivalence about its motivating forces, which in the case of qualified immunity may also be internally contradictory ones. When the law follows such a course, it is bound to generate ironies such as the creation of secondary burdens described above. This not only interferes with the coherent development of legal doctrine, but also makes it extraordinarily difficult to assess possible reform in a meaningful and thoughtful manner. Greater reflection on underlying principles and foundational concerns can provide us with better grounding for evaluating legal doctrine and theory. 